Illinois State University

ISU ReD: Research and eData

Theses and Dissertations

6-14-2019

\title{
Teachers' Perceptions of English Learners: A Multidimensional Scaling Approach
}

Cyndy Alvarez

Illinois State University, alvarez.cyndy.j@gmail.com

Follow this and additional works at: https://ir.library.illinoisstate.edu/etd

Part of the Bilingual, Multilingual, and Multicultural Education Commons, and the Psychology Commons

\section{Recommended Citation}

Alvarez, Cyndy, "Teachers' Perceptions of English Learners: A Multidimensional Scaling Approach" (2019). Theses and Dissertations. 1145.

https://ir.library.illinoisstate.edu/etd/1145

This Dissertation is brought to you for free and open access by ISU ReD: Research and eData. It has been accepted for inclusion in Theses and Dissertations by an authorized administrator of ISU ReD: Research and eData. For more information, please contact ISUReD@ilstu.edu. 


\section{TEACHERS’ PERCEPTIONS OF ENGLISH LEARNERS:}

\section{A MULTIDIMENSIONAL SCALING APPROACH}

\section{CYNDY ALVAREZ}

\section{Pages}

With an influx in immigration across the United States our educational policies have needed to change to meet the instructional needs of our students, especially our English Learners (Koyama, 2004; Mantero \& McVicker, 2006). Historically, these educational language policies were an outcome of court cases that highlighted discrimination and racist practices against our English Learners. These cases, such as the Chicano civil rights movements or East L.A. “walkouts” in 1968, Lau v. Nichols (1974), Serna v. Portales Municipal Schools (1974), Rios v. Read (1978), and U.S. v. Texas (1981), Plyver v. Doe (1982), Castaneda v. Pickard (1981), have resulted in policies that provide English Learners access to instruction and support in developing bilingualism. Despite all these language policies that advocate for English Learners' access to education, there have also been anti-bilingualism sentiments or "English-only" policies. These "English-only" policies are a reflection of individuals in our society being anti-English Learners.

The rise in culturally and linguistically diverse student population is made up of approximately four million of English Learners, with majority of students coming in with Spanish as their native language. Despite the changes in our student population becoming more culturally and linguistically diverse our teacher demographics continue to remain very homogenous encompassing of a majority White-middle class females. These differences between student and teachers have led to cultural and language mismatches that make teachers vulnerable 
to stereotypes about students. Previous studies have found that teachers hold misperceptions, stereotypes, myths, deficit-based perceptions, or majoritarian rules (Estrada, Gómez, \& RuizEscalante, 2009; Fránquiz, Salazar, \& DeNicolo, 2011; Gonzalez \& Ayala-Alcantar, 2008; Harper \& de Jong, 2004; Kolano \& King, 2015; Mantero \& McVicker, 2006; Marx, 2002/2009; Ortiz, 2011). These perceptions have been noted to impact teacher practices and instructional approaches, such as using a pedagogy of poverty (Diaz, Whitacre, Esquierdo, \& Ruiz-Escalante, 2013; Ghaouar, 2015; Harper \& de Jong, 2004). Research has suggested that teachers' perceptions influence students' academic performance and achievement (Diaz, Whitacre, Esquiero, \& Ruiz-Escalante, 2013; Glock \& Kovacs, 2013; Lumdsen, 1997; Mantero \& McVicker, 2006; Richardson, 1996).

Considering the strong implications teachers perceptions have upon student performance, this study sought to gather a comprehensive understanding of teachers' perceptions of English Learners. A comprehensive literature review of a mix of qualitative and quantitative based studies was used to gather over 400 teacher statements about English Learners. These statements were sorted into 28 categories that generated 92 consensus stimuli items for the card-sorting task. Participants included a total of 40 teachers (20 pre-service and 20 in-service teachers) from a Historically White institution and a school district in Illinois. Participants completed several questionnaires and card-sorting task that was analyzed with the use of Multidimensional Scaling (MDS). Findings generated a MDSCAL three-dimensional solution that was similar and significantly correlated with INDSCAL by subgroup (Pre-service and In-service) differences. Dimension 1 reflected Positive vs. Negative statements, Dimension 2 reflected statements about students (ELs) vs. statements about teachers, and Dimension 3 reflected Systemic Barriers vs. Resources encountered when teaching ELs. Therefore, all teachers hold similar perceptions and 
Pre-service and In-service teachers perceive English Learners similarly; however, In-service teachers attend two Dimension 2 twice as much than Pre-service teachers. Findings indicated that teachers perceptions are influenced by their Teaching Status (Pre-service or In-service), Frequency of Contact with ELs, and Professional Development. It was concluded that teaching experience matters.

KEYWORDS: multidimensional scaling, English Learners, teachers perceptions 


\title{
TEACHERS' PERCEPTIONS OF ENGLISH LEARNERS:
}

A MULTIDIMENSIONAL SCALING APPROACH

\author{
CYNDY ALVAREZ
}

A Dissertation Submitted in Partial

Fulfillment of the Requirements

for the Degree of

DOCTOR OF PHILOSOPHY

Department of Psychology

ILLINOIS STATE UNIVERSITY

2019 
C 2019 Cyndy Alvarez 


\section{TEACHERS' PERCEPTIONS OF ENGLISH LEARNERS:}

A MULTIDIMENSIONAL SCALING APPROACH

CYNDY ALVAREZ

COMMITTEE MEMBERS:

Matthew Hesson-McInnis, Co-Chair

Beth Hatt, Co-Chair

Karla Doepke

Gregory Bradswell 


\section{ACKNOWLEDGMENTS}

I want to acknowledge every Latinx youth, immigrant, and English Learner student that I have met along my graduate training; you all gave me some of the most meaningful memories as a school psychologist. You all have been the inspiration of this research study. I also want to thank and honor my ancestors for their sacrifices and all their luchas for me to enter higher education, spaces that we, as black and brown folk, historically were not allowed in.

I want to thank my familia and dedicate this accomplishment to them. Gracias a mi familia: mi mamá, papá, y mi hermano. Mamá gracias por siempre inculcarme el valor de la educación desde niña, mis logros son tus logros. Papá gracias por enseñarme los valores de trabajar duro y no rendirse. Gracias por siempre apoyarme, cuidarme, darme fuerzas y valentía. Todos los sacrificios que han hecho por mí, no han sido en vano. Josh, mi chicle desde bebé, thank you for always giving me unconditional support and love. You have been one of my greatest motivations in life since we were little. Thank you for encouraging me to pursue my dream of getting a PhD.

I want to thank my committee for their unconditional support and guidance throughout my graduate school. At one point I thought about leaving but you all made it possible for me to continue. Dr. Matthew Hesson-McInnis, thank you for being a wonderful co-chair; completion of this dissertation would not have been possible without all your guidance, encouragement, and wisdom. You gave me a space where I could share the importance of this topic, my story, and experiences. Dr. Beth Hatt, thank you for your unconditional love, moral support, and treating me like familia. You were one of the first that saw my potential and helped me find my voice. I will always tap into all of my cultural wealth, thank you. Dr. Karla Doepke, thank you for being part of this committee. I could not have asked for a better advisor and supervisor in my clinical 
experiences. Dr. Gregory Bradswell, thank you for embarking in the journey of being part of this committee and coming in with intentions of support and kindness.

I want to thank all of the folk that have been my accomplices and part of my community. Dr. Pamela Hoff, I will forever admire your wisdom and cultural wealth. Thank you for your warmth, advice, empowerment, and making UMOJA graduation one where I felt a true cultural celebration! Doctora Daisy Bueno, gracias por ser una de mis mejores amigas, por tu apoyo incondicional during grad school--from allowing me stay in your couch, to fixing a flat tire with me, to all the adventures we have shared. We made it! Javier, gracias por siempre ser mí calma en momentos de chaos, por tu amor, apoyo, y siempre cuidar de mí. Yesenia, gracias por toda la inspiración que me has invocado, eres una amiga a la cual admiro y respeto mucho. Tu historia es poderosa como las mariposas. Misty and Ashley, thank you for celebrating my accomplishments and being amazing sister-friends. You both helped me survive my last few years of grad school by giving me a friendship full of affirmation and love. Vicky Karahalios, thank you for being a wonderful friend and co-worker whom I have learned a lot from. I am grateful of all your kindness, love, and support you gave me throughout my internship year. Dr. Laura Swanlund, thank you for seeing all my potential, believing in me, and letting me share my experiences and perspectives. I am so grateful for all the guidance and opportunities you have provided throughout internship year.

Finally, thank you to everyone who walked by my side at some point in my life, you made an impact. Lo logramos! We made it!

C.A. 


\section{CONTENTS}

Page

ACKNOWLEDGMENTS

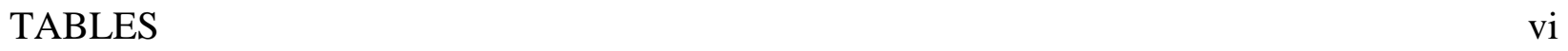

FIGURES vii

CHAPTER I: THE PROBLEM AND BACKGROUND 1

CHAPTER II: REVIEW OF LITERATURE $\quad 6$

Importance and Impact of Teachers' Perceptions upon Students $\quad 7$

Theoretical Explanation of Perceptions and Attitudes 9

Literature Review: Teachers' Perceptions towards English Learners 11

Deficit and Asset Based Perceptions towards English Learners 13

Factors Influencing Teachers' Perceptions of English Learners 22

Deconstructing Deficit-Based Perceptions 22

$\begin{array}{ll}\text { The Present Study } & 23\end{array}$

$\begin{array}{ll}\text { CHAPTER III: RESEARCH DESIGN } & 28\end{array}$

$\begin{array}{ll}\text { Participants } & 28\end{array}$

$\begin{array}{ll}\text { Materials } & 29\end{array}$

Stimuli for Card-Sorting Task $\quad 29$

Demographics and Background Questionnaire $\quad 30$

Truthfulness Stimuli Likert Rating Scale $\quad 30$

$\begin{array}{ll}\text { Critical Consciousness Scale } & 31\end{array}$

$\begin{array}{ll}\text { Procedure } & 32\end{array}$

Card-Sorting Practice $\quad 32$ 
Card-Sorting Task

Questionnaire Packet

Data Entry

Supporting Research

Data Analysis

Dimension Interpretation 38

Examining Group Differences $\quad 38$

$\begin{array}{ll}\text { CHAPTER IV: RESULTS } & 39\end{array}$

Card-Sorting Variables: Number of Piles, Labels, and Sorting Time 39

Multi-Dimensional Scaling Analysis with MDSCAL 41

Dimension Interpretation $\quad 42$

Individual Differences Scaling Analysis with INDSCAL 45

Participant-by-Participant Differences with INDSCAL 45

Pre-Service vs. In-Service Subgroup Differences with INDSCAL 47

Dimension Interpretation $\quad 49$

$\begin{array}{ll}\text { Subject Weights Analysis } & 50\end{array}$

$\begin{array}{ll}\text { Correlations with Other Factors } & 51\end{array}$

MDSCAL Dimensions, INDSCAL Dimensions, and Truthfulness Ratings 51

INDSCAL Dimensions and Critical Consciousness Variables 52

Repeated Measures MANOVAs $\quad 53$

Individual Factors Influencing Perceptual Dimensions 53 
$\begin{array}{ll}\text { CHAPTER V: DISCUSSION } & 60\end{array}$

Summary of Findings $\quad 62$

MDSCAL Results 63

INDSCAL Results 63

$\begin{array}{ll}\text { Correlations with Other Factors } & 64\end{array}$

$\begin{array}{ll}\text { Repeated Measures MANOVAS } & 65\end{array}$

Summary and Implications $\quad 66$

$\begin{array}{ll}\text { Limitations and Future Directions } & 68\end{array}$

$\begin{array}{ll}\text { REFERENCES } & 71\end{array}$

APPENDIX A: DEMOGRAPHICS QUESTIONNAIRE 79

APPENDIX B: PRACTICE CARDS 12

APPENDIX C: CARD-SORTING TASK INSTRUCTIONS 83

APPENDIX D: TRUTHFULNESS LIKERT RATING SCALE 85

APPENDIX E: CRITICAL CONSCIOUSNESS SCALE 91

APPENDIX F: CARD-SORTING TASK PILE NAMES 94

APPENDIX G: MDSCAL CONFIGURATION - DIMENSION 1 RANKINGS 101

APPENDIX H: MDSCAL CONFIGURATION - DIMENSION 2 RANKINGS 106

APPENDIX I: MDSCAL CONFIGURATION - DIMENSION 3 RANKINGS 111

APPENDIX J: INDSCAL SUBGROUP CONFIGURATION - DIMENSION 1 RANKINGS 116

APPENDIX K: INDSCAL SUBGROUP CONFIGURATION - DIMENSION 2

$\begin{array}{ll}\text { RANKINGS } & 121\end{array}$

APPENDIX L: INDSCAL SUBGROUP CONFIGURATION - DIMENSION 3

RANKINGS 


\section{TABLES}

Table

Page

1. Stimuli of Teachers' Perceptions of English Learners

2. Card-Sorting Task Outcomes in All 40 Participants

3. Card-Sorting Task Outcomes in Pre-service vs. In-service Participants

4. MDSCAL: Stress and $\mathrm{R}^{2}$ Values for Dimensions 6-2

5. INDSCAL: Stress and $\mathrm{R}^{2}$ Values for Dimensions 6-2

6. Correlations between MDSCAL Dimensions and INDSCAL Dimensions

7. INDSCAL: Stress and $\mathrm{R}^{2}$ Values for Dimensions 5-2

8. Correlations between MDSCAL Dimensions and INDSCAL Subgroup Dimensions

9. Subject Weights on Dimensions 1, 2, and 3 by Teaching Status

10. Correlations between Dimensions and Average Truthfulness Ratings

11. Correlations between Critical Consciousness Subscales and Dimensions

12. Correlations across Critical Consciousness Subscales

13. Descriptives on Participants Education Training 


\section{FIGURES}

Figure $\quad$ Page

1. Example of participant 001 similarity ratings of 93 items with item 34 deleted 35

2. Stimulus configuration derived in three dimensions 42

3. Teaching Status means and Dimension weights 54

4. ELL Frequency Contact (re-coded) means and Dimension weights 57

5. Professional Development means and Dimension weights 59 


\section{CHAPTER I: THE PROBLEM AND BACKGROUND}

During the 1960s the teaching force had an increase of teachers for English Learners due to the increase of immigrants and refugee children in the United States (Mantero \& McVicker, 2006). This influx led to educational policies and controversies about the use of non-English languages in educational settings (Shin, Leal, \& Ellison, 2015). Since then, there have been various federal, state, and local policies that have played a role in accommodating or regulating language programs in educational settings. For example, bilingual education policies started with Congress passing the Bilingual Education Act (1968) as a result of civil rights and Chicano movements (Mantero \& McVicker, 2006; Shin et al., 2015). The Bilingual Education Act was a program for students between the ages of 3 and 8 to address the needs of students with limited English speaking abilities. This act was also an action to decrease drop-out rates given that there were higher drop-out rates among non-English speakers than among English-speaking peers.

There were also federal court cases that influenced bilingual education policies as well as Latinx policies. For example, Lau v. Nichols, 414 U.S. 563 (1974), found that public schools in San Francisco, California were denying equal educational opportunities to Chinese Americans due to their limited English proficiency. The Supreme Court ruled that non-English speakers were being denied a meaningful education and that public-school policies violated the Civil Rights Act of 1964; thus, the school district was required to provide equal opportunities and access to all students. Other court decisions that influenced bilingual education policies and programs that advocated for meaningful and appropriate education for English Learners were

Serna v. Portales Municipal Schools (1974), Rios v. Read (1978), and U.S. v. Texas (1981). These court cases were related to denying equal educational opportunities to English Learners 
and, consequently, supported the development of language programs to accommodate English Learners through bilingual or bicultural programs.

Other important Supreme Court and Federal Court cases that impacted language programs include Plyver v. Doe (1982) and Castañeda v. Pickard (1981) (Mantero \& McVicker, 2006). The first case ruled that the Fourteenth Amendment prohibits states from denying students a free appropriate public education on account of their immigration status. This decision has protected English Learners who are often immigrants, including undocumented immigrants. The second case determined that school districts must comply with the Equal Education Opportunities Act (1974) after it was determined that the school district was failing to meet the needs of English Learners. This case resulted from a Mexican-American father claiming racial and ethnic discrimination towards his children from Raymondville Independent School District in Texas.

Despite federal policies supporting bilingual language education programs, state policies have responded to bilingual education programs differently. These responses have aimed to limit or eliminate bilingual education programs. Some of these state policies include California's Proposition 227 (English Language in Public Schools Statue, 1998), Arizona's Proposition 203 (English for the Children, 2000), and Colorado's Initiative 31 (English for the Children of Colorado, 2002). These policies have proposed an ideology of English-only or adopting English as the official language in the United States, thus education and instruction should be Englishonly. This ideology has been observed to be adopted in more than thirty states, which have passed legislation or amendments promoting English-only instruction (Mantero \& McVicker, 2006; Shin et al., 2015). 
It is evident that there have been socio-political, cultural influencing language policies that have impacted the immigrant and English Learners population in education settings. Shin and colleagues (2015) argue that these language policies have targeted Latinx immigrants and the Spanish language. This focus may be a result of the sentiments and views toward Latinx immigrants as, "they are not assimilating, they are self-segregating... maintain their language and identifying with one another, not American" (Buchannan, 2007, p. 42, as cited in Shin et al., 2015, p. 378). These attitudes have been a result of "a common belief that large-scale immigration may bring linguistic change that threatens the position of English as a national language and thereby harms the unity of the United States" (Shin et al., 2015, p. 378). Thus, Latinx immigrants' behaviors and values have been perceived to be a threat against the symbolic American patriotism values (Shin et al., 2015).

Bronfenbrenner (1979) established a conceptual framework for understanding how larger and smaller scale systems interact, which suggests that these socio-political attitudes from a larger macrosystem will ultimately influence and impact smaller microsystems, which encompass teacher's beliefs. Beliefs have been noted to serve as indicators of our decisions, which is consistent with the literature about teachers' beliefs and their decisions (Bandura 1986; Fang, 1996; Mantero \& McVicker, 2006). Overall, research has indicated that teacher attitudes have been found to influence their teaching practices and consequently impact student's achievement and performance at school (Ghaouar, 2015; Glock \& Kovacs, 2013; Lumsden, 1997; Mantero \& McVicker, 2006; Pettit, 2011; van der Bergh et al., 2010, as cited in Glock \& Kovacs, 2013).

Currently, there are more than four million English Learners in public schools, with majority of them speaking Spanish as their native language, encompassing about 10 percent of 
our K-12 student population (NCELA, 2017; NEA, 2017; U.S. Department of Education, 2017). Despite student demographics becoming more diverse, the teaching force remains predominantly White middle class (Salerno \& Kibler, 2013). This shift in student demographics leads to a mismatch between teachers' and students' personal experiences and background; as a result, Latinx English Learners tend to be vulnerable to experience teacher-based prejudices, biases, microaggressions, discrimination, stereotypes, misconceptions, and deficit oriented perceptions (Benner \& Graham, 2011; Ford, Scott, Moore, \& Amos, 2013; Gonzalez \& Ayala-Alcantar, 2008; Staats, 2016). English Learners have also been found to be vulnerable to instruction from a pedagogy of poverty, due to the deficit oriented views teachers have about English Learners (Diaz, Whitacre, Esquierdo, \& Ruiz-Escalante, 2013). All these implicit and explicit perceptions contribute to teacher attitudes, which ultimately perpetuate the achievement gap (Ferguson, 1998, as cited in Callahan, 2005). Therefore, it is critical to continue examining teachers (preservice and in-service) attitudes toward Latinx English Learners. The purpose of the current study is to understand the various perceptual dimensions employed by teachers as they consider English Learners and identify the individual differences among teachers that may explain the differential salience of these dimensions.

Prior research studies have examined teachers' attitudes and perceptions towards English Learners through qualitative and quantitative methods (Byrnes, Kiger, \& Manning, 1997; Diaz et al., 2013; Doorn \& Schumm, 2013; Glock \& Kovacs, 2013; Gonzalez, Ayala-Alcantar, 2008; Griego, 2002; Harper \& de Jong, 2004; Kayi-Aydar, 2015; Kolano \& King, 2015; Mantero \& McVicker, 2006; Markos, 2012; Marx, 2000/2002; Penfield, 1987; Pettit, 2011; Salerno \& Kibler, 2013; Sas, 2009; Walker, Shafer, \& Iiams, 2004; Youngs \& Youngs, 2001). The significant findings of these studies have made important contributions to the literature about 
teachers' attitudes. All of these studies, however, have used methods (e.g., used surveys, openended questionnaires, journal entries, work samples, or interviews) that pose limitations in measuring implicit attitudes. Another limitation in the use of these methods is that these tasks may allow teachers to use a conscious, thoughtful evaluation of English Learners (Glock \& Kovacs, 2013). Another limitation in the use of surveys and self-report measures is that they are known to be influenced by socially desirability; thus, responses may have been more positively skewed. To address the social desirability phenomenon and obtain teachers' implicit perceptions of English Learners, the current study will assess perceptions using a card-sorting task. The sorting data will then be analyzed using Non-metric Multidimensional Scaling (NMDS), which creates a configuration or map that displays dissimilarities among the stimuli as distances within the configuration, which will potentially allow for the identification of perceptual dimensions (Rosenberg \& Kim, 1975). Further, an individual differences NMDS method will provide dimension weights that describe the degree to which each participant (or group of participants) attend to each perceptual dimension. The current study will contribute to the research of teacher attitudes by applying the use of NMDS methodology, which will be the first in this area of research. The study will identify the most salient characteristics attributed by teachers towards Latinx English Learners. 


\section{CHAPTER II: REVIEW OF LITERATURE}

Since the 1960s there has been a change in demographics due to Latinx immigration, leading to Spanish becoming the fastest-growing language in the United States with approximately 37 million speakers (Pew Research Center, 2013). This lingual shift has changed the focus from European foreign languages to the Spanish language (Shin et al., 2015). With the growth and change in our nations' demographics, our classrooms' demographics have also changed to encompass more students from culturally and linguistically diverse backgrounds, including English Learners. English Learners (ELs), or English Language Learner (ELLs), or Limited English Proficiency (LEP), are all terms used interchangeably to describe "a pupil who was not born in the United States or whose native language is a language other than English or who comes from an environment where a language other than English is dominant; and whose difficulties in speaking, reading, writing, or understanding the English language may be sufficient to deny the individual the ability to successfully achieve in classrooms where the language of instruction is English, or the opportunity to participate fully in society (Artiles, Rueda, Salazar, \& Higareda, 2005, p. 284).

The U.S. Department of Education and the National Clearinghouse for English Language Acquisition (NCELA) reported that in the school year of 2014-2015 there were 4,806,662 English Learners in the United States, which represented about 10 percent of the total K-12 student population (NEA, 2017). Additionally, the National Education Association (NEA) policy brief report reported that about 76 percent of elementary schools and 56 percent of secondary school English Learners are native-born U.S. citizens (Capps, Fix, Murray, Ost, Passel, \& Herwantoro, 2005; National Education Association, 2008). Thus, English Learners have become the fastest-growing student population, with two-third of them coming from low-income 
families, and three out of four English Learner students are Spanish-speaking (English language learners face unique challenges, 2008).

English Learners (ELs) have been noted to encounter challenges such as low academic performance, low achievement scores, and high dropout rates (NEA, 2008). The academic challenges faced by English Learners in our educational system raise concerns of the inequities currently facing these students in our educational systems. As a result of these challenges, it is essential to consider the multifaceted factors that may be perpetuating the educational inequities per se. One of the most evident factors is the mismatch between teachers' and students' cultural and linguistic backgrounds. Carjuzaa (2007) indicates that teachers are becoming more homogenous (i.e., predominantly white, female, monolingual, and middle class), whereas students are becoming more culturally and linguistically diverse. This mismatch is a concern, and studies have found that White teachers tend to hold negative dispositions towards students who are culturally and linguistically different from them (Carjuzaa, 2007). Additionally, Glock and Kovacs (2013) stressed that EL students face disadvantages in educational settings due to the decisions that are made by teachers (i.e., predominately monolingual, White, middle-class teachers referring lower income, bilingual, black and brown children for special education services). Glock and Kovacs established that teachers are involved in tracking students and making special education referrals based on their judgements of those students. Thus, teachers' beliefs, perceptions, and attitudes about their students have significant impacts upon those students' education.

\section{Importance and Impact of Teachers' Perceptions upon Students}

Research has found that teachers' implicit biases have detrimental effects in our educational system, including student performance. For example, "racial disparities in discipline 
can occur even when black and white students behave similarly" (Staats, 2016, p. 33). Teachers' implicit biases not only affect grading and evaluation of performance of students but also influence and shape teacher expectations of student achievement. As explicated below, studies have found that teacher's expectations about student performance are influenced by their implicit ethnic biases. Thus, teachers' expectations of achievement of students of color tend to be lower or from a deficit given their implicit biases.

Teachers' attitudes and perceptions, including their beliefs, have been found to have stronger influences than their knowledge upon their teaching approaches (Ghaouar, 2015). Thus, teachers' attitudes impact students' learning (Diaz et al., 2013). Research has also found supporting evidence that teachers' attitudes and perceptions influence their teaching approaches, pedagogy, and classroom decisions that ultimately have an impact on students' achievement and academic performance (Diaz et al., 2013; Glock \& Kovacs, 2013; Lumdsen, 1997; Mantero \& McVicker, 2006; Richardson, 1996). For example, studies about teachers' attitudes towards racial minority students, which include English Learners, have found that racial minority students also tend to have lower standardized test scores when they are in a classroom with teachers who have negative implicit attitudes (van der Bergh et al., 2010, as cited in Glock \& Kovacs, 2013). When pre-service teachers have positive implicit attitudes about racial minority students, they tend to rate minority students more positively on academics (Glock \& Karbach, 2015; Glock \& Kovacs, 2013). Therefore, teachers' implicit attitudes have a strong impact upon students' achievement and may perpetuate the achievement gap (Ferguson, 1998, as cited in Callahan, 2005). In the contrary, teachers with attitudes that affirm and validate student's cultural, linguistic and personal identities create classrooms where students feel respected, liked, and appreciated (Mantero \& McVicker, 2006). 
Teacher attitudes have also been found to influence the relationship they have with their students (Cummins, 2001). Teachers' attitudes have an impact upon students because students internalize these perceptions (Lumsden, 1997). Students learning a second language have also indicated that teachers' attitudes are essential in their achievement in that language (Abu-Rabia, 2004). Students indicated that teachers with characteristics of being relaxed, open, and having clear communication were "good teachers." Borna (2015) also found that teachers' attitudes will facilitate English Learners' motivation towards learning a second language as well as their ability to achieve a successful self-image. In fact, English Learners may experience anxiety and competitiveness, which can be lessened depending on teachers attitudes. In summary, it can be concluded that teachers' attitudes, perceptions, and beliefs have significant implications upon students' achievement, esteem, motivation, performance, and classroom environment.

\section{Theoretical Explanation of Perceptions and Attitudes}

Theoretically, attitudes have been described as consisting of explicit and implicit attitudes (Glock \& Kovacs, 2013). Explicit attitudes are an "evaluation of an object resulting from thoughtful, conscious reflection" (p. 512). Implicit attitudes are "automatic evaluation of an object" (p. 504). These conscious or unconscious attitudes are what guide our behaviors according to the Motivation and Opportunity as Determinants (MODE) model (Fazio, 1990; Fazio \& Towles-Schwen, 1999; Olson \& Fazio, 2009). The MODE model explains the relation between attitudes and behaviors. In other words, teachers' behaviors can be explained based on their implicit or explicit attitudes. The MODE model stipulates that, under specific conditions (i.e., enough time and plentiful resources), individuals' conscious processes will drive their behaviors guided by their explicit attitudes. However, when individuals lack time and resources, 
they will rely on their automatic processes, thus their behaviors are guided by their implicit attitudes.

Explicit and implicit attitudes have also been explained by a framework that accounts for how individuals make sense and understand the world (Staats, 2016). Kahneman (2011) presented a cognitive functioning framework that divided processes into two systems: System 1 and System 2. The first system is responsible for what occurs outside conscious awareness and functions automatically and extremely fast, which is what is responsible for implicit biases. The second system is responsible for the conscious processing, for tasks that require effort and concentration, which is responsible for explicit biases. Staats (2016) explained that teachers tend to rely upon System 1 given the conditions that they face throughout the course of a school day. Teachers are often placed under ambiguous situations with incomplete information, subjected to time constraints, fatigued, or preoccupied by conflicting tasks. Therefore, System 1 will influence their decisions and actions that are based on implicit biases. For example, a teacher must make a quick decision about a child's misbehavior, thus relying on their implicit biases in determining the severity of discipline in response to their misbehavior.

Despite the clear defining of attitudes, it should be noted that existing research about teachers views on students has used several terms interchangeably and inconsistently. Across the extant literature, the following terms (attitudes, beliefs, perceptions, perspectives, judgments, etc.) have been used to address a relatively similar construct that aims to get at the most salient perceptions teachers form for their students. Sas (2009) distinguished and defined these different terms and concluded that this inconsistency has contributed to the difficulty of defining and measuring teachers' attitudes. Despite the inconsistency in terminology, research findings emphasize the importance of continuing to research teachers' attitudes and perceptions. For the 
purpose of this study, I will use the term perceptions as the construct of interest, and the literature review will include extant studies that include any of the mentioned concepts. The focus in this literature review will be to obtain a comprehensive understanding of the perceptions teachers have towards English Learners.

\section{Literature Review: Teachers' Perceptions towards English Learners}

In relation to attitudes, which are influenced by implicit and explicit processes, research has found a range of attitudes toward, perceptions of, and beliefs about English Learners. Thus, pre-service teaching training programs continue to encourage the importance for teachers to analyze their beliefs and perceptions. These attitudes and perceptions have been researched in relation to culturally and linguistically diverse students, ethnic/racial minority students, and immigrant students, which include English Learners.

In a literature review, Glock and Kovacs (2013) found that teachers' attitudes will vary depending on whether those attitudes are explicit or implicit. Teachers' explicit attitudes toward racial minority students, immigrant students, and English Learners have been found to be positive (Glock \& Kovacs, 2013; Sas, 2009; Youngs \& Youngs, 2001). Teachers’ implicit attitudes, however, tend to be more negative toward racial minority students than toward White students. Additionally, teachers' implicit attitudes towards White students tend to be more positive, and implicit attitudes towards racial minority students tend to be neutral (Glock \& Karbach, 2015). Considering that English Learners are commonly considered racial minority students, it can be expected that teachers will hold explicit positive perceptions towards English Learners, as well as neutral to negative implicit perceptions. Research has also found that preservice teachers' perceptions towards English Learners, while not negative, their perceptions are 
minimized, trivialized, and reflect a more ethnocentric perception (Doorn \& Schuum, 2013; Pappamihiel, 2007).

Existing literature reviews have found important contributions about teachers' perceptions towards English Learners (Mantero \& McVicker, 2006; Pettit, 2011). Some of the significant findings when analyzing teachers of English Learners, both in-service mainstream teachers and teachers who work predominantly with English Learners, suggest that both groups of teachers have significantly different perceptions of English Learners. English Language Learning teachers tend to have more positive perceptions than mainstream teachers. In both groups of teachers, their perceptions tend to be more positively influenced when they have taught from six to ten years, taken undergraduate courses or graduate training about language minority students, and have had more staff development training. Another significant finding that is reflected across the literature is that teachers hold various misconceptions about English Learners, lack knowledge about Second Language Acquisition, and view themselves as not responsible for teaching English Learners (Pettit, 2011).

These teachers' misconceptions about English Learners are important to analyze, considering that they influence teachers' perceptions and instructional approaches (Ghaouar, 2015; Harper \& de Jong, 2004). These misperceptions further explain teachers' instructional approaches being embedded in a pedagogy of poverty (Diaz et al., 2013). Diaz and colleagues have defined the term pedagogy of poverty as an instructional approach that focuses on students' lower level skills and passive learning; thus, students are treated as incapable of performing to higher order level skills or challenging curriculum. These instructional approaches and pedagogy of poverty are also related to deficit-based perceptions that teachers have about English Learners. Ortiz (2011) explained that teachers with deficit perspectives tend to blame problems, including 
low performance, upon the students, their families, or their cultures. In fact, a study found that approximately $89 \%$ of teachers have deficit perceptions of their Latinx students. A review of the extant literature suggests, therefore, that the perceptions teachers have about English Learners can be categorized as deficit-based or asset-based perceptions; and this distinction contributed to the development of materials (specifically stimuli statements) used in the current study.

\section{Deficit and Asset Based Perceptions towards English Learners}

In the literature, most studies designed to assess teachers' perceptions of English Learners have been conducted among pre-service teachers who are taking a course focused on multicultural, diversity, learning to work with English Learners, or second language acquisition (e.g., Doorn \& Schumm, 2013; Gonzalez \& Ayala-Alcantar, 2008; Kayi-Aydar, 2015; Kolano \& King, 2015; Lucas \& Frazier, 2014; Markos, 2012; Marx 2002/2009; Pappamihiel, 2007).

Findings indicated that pre-service teachers in these courses initially had deficit-based or narrow perceptions of English Learners but managed to transition to more asset-based perceptions, more positive attitudes, or a broader understanding of English Learners (Doorn \& Schumm, 2013; Kolano \& King, 2015; Markos, 2012; Marx, 2002/2009; Pappamihiel, 2007).

Teachers' deficit-based perceptions consist of teachers' misconceptions, misperceptions, stereotypes, and myths about English Learners (Estrada, Gómez, \& Ruiz-Escalante, 2009; Gonzalez \& Ayala-Alcantar, 2008; Harper \& de Jong, 2004; Kolano \& King, 2015; Marx, 2002/2009; Ortiz, 2011). These deficit-perceptions revolve around language and cultural myths about Latinx English Learners, as well as misunderstanding the development of second language and instructional approaches needed for English Learners (Estrada et al., 2009; Gonzalez \& Ayala-Alcantar, 2008; Harper \& de Jong, 2004; Kolano \& King, 2015). The content of these 
perceptions of English Learners aligned in several categories about English Learners that were used in the development of stimuli for the current study, as explicated below.

Fránquiz, Salazar, and DeNicolo (2011) described “majoritarian tales", which are internalized "narratives rooted in deficit assumptions of race, culture, and language" (p. 281). These majoritarian tales are described as perceptions positioned in the dominant norms and are used to silence the lived experiences of people of color. Both teachers who are White and teachers of racial/ethnic minority background have been noted to be vulnerable to internalize these majoritarian tales, which contribute to perpetuating deficit-based perceptions about English Learners. In contrast, teachers' asset-based perceptions included principles that research has identified relevant to fostering linguistically responsive teachers (Lucas, Villegas, \& FreedsonGonzalez, 2008). Asset-based perceptions are therefore the opposite of deficit-based perceptions. These asset-based perceptions often reflect a counter-narrative of the majoritarian tales described by Fránquiz et al. (2011). In the extant literature, the counter-narrative, asset-based perceptions of English Learners were noted to revolve around similar categories as that of the deficit-based perceptions, such as language and cultural perceptions.

In reviewing the extant literature about teachers' perceptions of English Learners, 28 categories were identified and were used to conceptualize teachers' perceptions towards English Learners. The process of recording these statements, development of these categories, and then development of consensus stimuli items is explained in Chapter III. Table 1 includes the category number, consensus stimuli, and references related to developing the consensus stimuli items. 
Table 1

Stimuli of Teachers' Perceptions of English Learners

\begin{tabular}{|c|c|c|c|}
\hline Category & $\begin{array}{l}\text { Stimuli } \\
\text { Item }\end{array}$ & Consensus Stimuli & References \\
\hline 1 & $\begin{array}{l}2 \\
3\end{array}$ & $\begin{array}{l}\text { English Learners are lazy and don't care about } \\
\text { their education } \\
\text { English Learners are members of a gang } \\
\text { English Learners care about their education, } \\
\text { thus they are well-behaved }\end{array}$ & $\begin{array}{l}\text { Marx (2006) } \\
\text { Gonzalez \& Ayala- } \\
\text { Alcantar (2008) } \\
\text { Irizarry (2011) } \\
\text { Mantero \& McVicker } \\
\text { (2006) } \\
\text { Markos (2012) } \\
\text { Pettit (2011) } \\
\text { Kolano \& King (2015) } \\
\text { Irizarry (2011) } \\
\text { Marx (2000). }\end{array}$ \\
\hline 2 & 10 & $\begin{array}{l}\text { If English Learners would be more intelligent } \\
\text { they would learn English more quickly } \\
\text { English Learners have difficulties because they } \\
\text { are not very intelligent } \\
\text { English Learners have little knowledge to build } \\
\text { upon the classroom } \\
\text { English Learners have street smarts but not } \\
\text { school smarts } \\
\text { English Learners with an accent are less } \\
\text { intelligent } \\
\text { English Learners language skills are not } \\
\text { indicative of their intelligence } \\
\text { English Learners have the capacity to learn } \\
\text { despite their language skills }\end{array}$ & $\begin{array}{l}\text { Marx (2006) } \\
\text { Barrera (2014) } \\
\text { Bianco \& Harris (2014) } \\
\text { Callahan (2005) } \\
\text { Franquiz, Salazar, } \\
\text { DeNicolo (2011) } \\
\text { Gonzalez \& Ayala- } \\
\text { Alcantar (2008) } \\
\text { Jiménez (n.d.) } \\
\text { Kolano \& King (2015) } \\
\text { Marx (2000) } \\
\text { de Jong, Harper, \& } \\
\text { Coady (2013) } \\
\text { Thomas \& Collier } \\
\text { (1997) } \\
\text { Wolfram (2013) }\end{array}$ \\
\hline 3 & $\begin{array}{l}11 \\
12\end{array}$ & $\begin{array}{l}\text { I feel more comfortable working with English } \\
\text { Learners than other minority students } \\
\text { I can relate to the struggles English Learners } \\
\text { encounter and understand their needs }\end{array}$ & $\begin{array}{l}\text { Marx (2006) } \\
\text { Marx (2000) } \\
\text { Kayi-Aydar (2013) } \\
\text { Kayi-Aydar (2013) } \\
\text { Wong, Indiatsi, \& Wong } \\
(2016)\end{array}$ \\
\hline 4 & 14 & $\begin{array}{l}\text { English Learners are typically illegal } \\
\text { immigrants and drain tax payer resources } \\
\text { English Learners' families do not want to learn } \\
\text { English }\end{array}$ & $\begin{array}{l}\text { Marx (2006) } \\
\text { Kolano \& King (2015) } \\
\text { Markos (2012) }\end{array}$ \\
\hline
\end{tabular}

(Table Continues) 
Table 1. Continued

\begin{tabular}{|c|c|c|c|}
\hline Category & $\begin{array}{l}\text { Stimuli } \\
\text { Item }\end{array}$ & Consensus Stimuli & References \\
\hline 5 & 15 & $\begin{array}{l}\text { English Learners often do not receive support in } \\
\text { schools } \\
\text { English Learners often do not receive the } \\
\text { support they need from home } \\
\text { English Learners tend to go to the worst schools, } \\
\text { and the worst schools have the most English } \\
\text { Learners }\end{array}$ & $\begin{array}{l}\text { Marx (2006) } \\
\text { Marx (2006) } \\
\text { Becerra (2012) } \\
\text { Doorn \& Schumm } \\
\text { (2013) } \\
\text { Markos (2012) } \\
\text { Walker, Shafer, \& Iiams } \\
\text { (2004) }\end{array}$ \\
\hline 6 & $\begin{array}{l}18 \\
19\end{array}$ & $\begin{array}{l}\text { English Learners are poor } \\
\text { English Learners come from low income } \\
\text { families } \\
\text { The faster English Learners students assimilate } \\
\text { the better of they will be } \\
\text { The more English Learners insist in maintaining } \\
\text { their culture and language the slower they will } \\
\text { be to assimilate and learn English and/or the } \\
\text { worst off they will be }\end{array}$ & $\begin{array}{l}\text { Marx (2006) } \\
\text { Marx (2000) } \\
\text { Franquiz, Salazar, } \\
\text { DeNicolo (2011) } \\
\text { Gonzalez \& Ayala- } \\
\text { Alcantar (2008) } \\
\text { Sas (2009) } \\
\text { Shin, Leal, \& Ellison } \\
\text { (2015) } \\
\text { Walker, Shafer, \& Iiams } \\
\text { (2004) }\end{array}$ \\
\hline 7 & 22 & $\begin{array}{l}\text { English Learners are at a higher risk for } \\
\text { behavioral and/or learning difficulties }\end{array}$ & $\begin{array}{l}\text { Marx (2006) } \\
\text { Becerra (2012) } \\
\text { Franquiz, Salazar, } \\
\text { DeNicolo (2011) }\end{array}$ \\
\hline 8 & $\begin{array}{l}23 \\
24 \\
25 \\
26\end{array}$ & $\begin{array}{l}\text { English Learners' teachers should not be held } \\
\text { accountable for their achievement } \\
\text { English Learners are so far behind they will } \\
\text { never catch up } \\
\text { Teachers have low expectations from English } \\
\text { Learners } \\
\text { English Learner students are more motivated to } \\
\text { succeed than many of their native English- } \\
\text { speaking peers } \\
\text { English Learners will be academically } \\
\text { successful, and are just as capable of going to } \\
\text { college as native English speakers }\end{array}$ & $\begin{array}{l}\text { Marx (2006) } \\
\text { Marx (2000) } \\
\text { (Pew Hispanic Center, } \\
\text { 2004) (Becerra, 2012) } \\
\text { (College Board, 2007) } \\
\text { (Becerra, 2012) } \\
\text { (Portes \& Rumbaut, } \\
\text { 2001) (Becerra, 2012) } \\
\text { Callahan (2005) } \\
\text { Doorn \& Schumm } \\
\text { (2013) } \\
\text { Irizarry (2011) } \\
\text { Pettit (2011) } \\
\text { Walker, Shafer, \& Iiams } \\
\text { (2004) } \\
\text { Sas (2009) }\end{array}$ \\
\hline
\end{tabular}

(Table Continues) 
Table 1. Continued

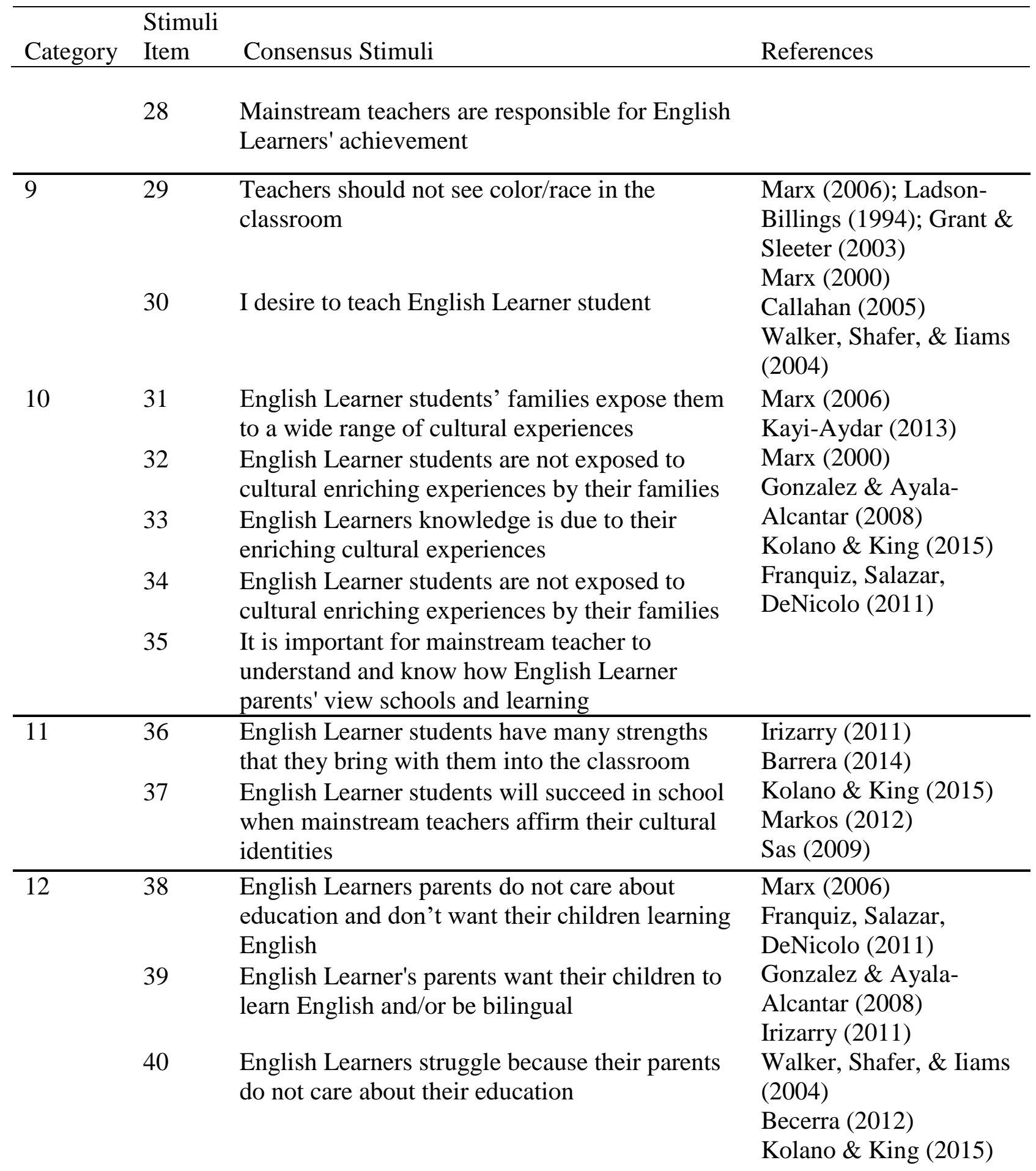

(Table Continues) 
Table 1. Continued

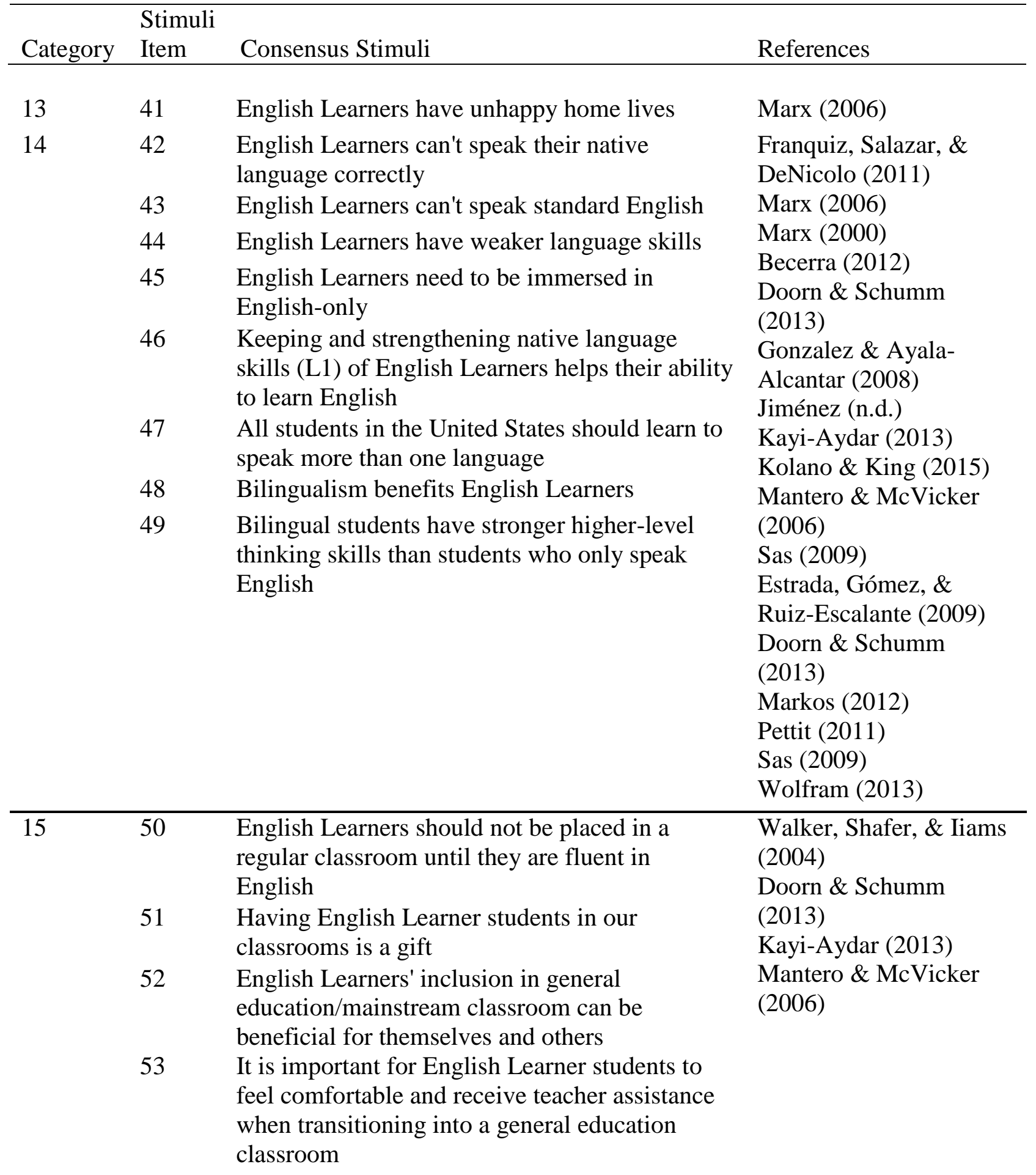

(Table Continues) 
Table 1. Continued

\begin{tabular}{|c|c|c|c|}
\hline Category & $\begin{array}{l}\text { Stimuli } \\
\text { Item }\end{array}$ & Consensus Stimuli & References \\
\hline \multirow[t]{10}{*}{16} & 54 & $\begin{array}{l}\text { Relying on their native language is a barrier to } \\
\text { learning English }\end{array}$ & \multirow{10}{*}{$\begin{array}{l}\text { Estrada, Gómez, \& } \\
\text { Ruiz-Escalante (2009) } \\
\text { Franquiz, Salazar, \& } \\
\text { DeNicolo (2011) } \\
\text { Gonzalez \& Ayala- } \\
\text { Alcantar (2008) } \\
\text { Harper \& de Jong (2004) } \\
\text { Pettit (2011) } \\
\text { Walker, Shafer, \& Iiams } \\
\text { (2004) } \\
\text { Doorn \& Schumm } \\
\text { (2013) } \\
\text { Jiménez (n.d.) } \\
\text { Lucas, Villegas, \& } \\
\text { Freedson-Gonzalez } \\
\text { (2008) } \\
\text { Markos (2012) }\end{array}$} \\
\hline & 55 & $\begin{array}{l}\text { English Learners second language acquisition } \\
\text { process involves accessing their native language }\end{array}$ & \\
\hline & 56 & $\begin{array}{l}\text { Spanish language skills are helpful in learning } \\
\text { English language as a second language }\end{array}$ & \\
\hline & 57 & $\begin{array}{l}\text { English Learners social language skills occur } \\
\text { before academic language skills }\end{array}$ & \\
\hline & 58 & $\begin{array}{l}\text { English Learners who learn to read and write in } \\
\text { their native language first acquire stronger }\end{array}$ & \\
\hline & & English language and literacy skills later. & \\
\hline & & & \\
\hline & & & \\
\hline & & & \\
\hline & & & \\
\hline \multirow[t]{4}{*}{17} & \multirow[t]{4}{*}{59} & \multirow{4}{*}{$\begin{array}{l}\text { Bilingual or language programs are not } \\
\text { necessary and divert resources that would be } \\
\text { better spent elsewhere, such as gifted programs }\end{array}$} & Sas (2009) \\
\hline & & & \\
\hline & & & Markos (2012) \\
\hline & & & $\begin{array}{l}\text { Walker, Shafer, \& Iiams } \\
(2004)\end{array}$ \\
\hline \multirow[t]{7}{*}{18} & \multirow[t]{2}{*}{60} & \multirow{2}{*}{$\begin{array}{l}\text { English Learners will not succeed without a } \\
\text { native English-speaking role model }\end{array}$} & Marx (2006) \\
\hline & & & Marx (2000) \\
\hline & \multirow[t]{2}{*}{61} & \multirow{2}{*}{$\begin{array}{l}\text { English Learners need to be helped become } \\
\text { Americanized }\end{array}$} & \multirow{2}{*}{$\begin{array}{l}\text { Sas (2009) } \\
\text { Kayi-Adar (2013) }\end{array}$} \\
\hline & & & \\
\hline & 62 & $\begin{array}{l}\text { English Learner students need support from } \\
\text { teachers beyond academics }\end{array}$ & $\begin{array}{l}\text { Mantero \& McVicker } \\
\text { (2006) }\end{array}$ \\
\hline & \multirow[t]{2}{*}{63} & \multirow{2}{*}{$\begin{array}{l}\text { English Learners need teachers that provide a } \\
\text { support system and guides them in schools }\end{array}$} & Markos (2012) \\
\hline & & & $\begin{array}{l}\text { Walker, Shafer, \& Iiams } \\
\text { (2004) }\end{array}$ \\
\hline \multirow[t]{3}{*}{19} & \multirow[t]{2}{*}{64} & \multirow{3}{*}{$\begin{array}{l}\text { English Learners are aggressive; I would worry } \\
\text { for my safety in teaching in a school with a lot } \\
\text { of English Learners } \\
\text { I fear teaching English Learners, I would be } \\
\text { uncomfortable }\end{array}$} & Marx (2006) \\
\hline & & & $\begin{array}{l}\text { Shin, Leal, \& Ellison } \\
(2015)\end{array}$ \\
\hline & 65 & & Kolano \& King (2015) \\
\hline
\end{tabular}

(Table Continues) 
Table 1. Continued

\begin{tabular}{|c|c|c|c|}
\hline Category & $\begin{array}{l}\text { Stimuli } \\
\text { Item }\end{array}$ & Consensus Stimuli & References \\
\hline & 66 & I feel prepared in teaching English Learners & \\
\hline 20 & 67 & $\begin{array}{l}\text { Teachers' racism impacts English Learners } \\
\text { achievement }\end{array}$ & Marx (2006) \\
\hline 21 & 68 & $\begin{array}{l}\text { Only teachers of color can be effective teaching } \\
\text { English Learners or relate to English Learner } \\
\text { students } \\
\text { I prefer to teach students from similar } \\
\text { backgrounds as me. } \\
\text { Cultural and linguistic differences between } \\
\text { students and teachers inhibits effective } \\
\text { education of English Learners }\end{array}$ & $\begin{array}{l}\text { Marx (2000) } \\
\text { Becerra (2012) } \\
\text { Walker, Shafer, \& Iiams } \\
\text { (2004) } \\
\text { Marx (2006) } \\
\text { Doorn \& Schumm } \\
\text { (2013) } \\
\text { Wong, Indiatsi, \& Wong } \\
\text { (2016) } \\
\text { Kolano \& King (2015) }\end{array}$ \\
\hline 22 & $\begin{array}{l}71 \\
72 \\
73 \\
74 \\
75 \\
76\end{array}$ & $\begin{array}{l}\text { Most teachers are not prepared in working with } \\
\text { English Learners } \\
\text { Teachers need special training in working with } \\
\text { English Learners } \\
\text { Most teachers don't want to work with English } \\
\text { Learners } \\
\text { Training all teachers to work with English } \\
\text { Learners is a waste of resources } \\
\text { English Learners need teachers that can create } \\
\text { culturally inclusive learning materials } \\
\text { I know specific strategies for designing } \\
\text { instruction that is responsive to students' } \\
\text { language needs } \\
\text { I know specific strategies for designing } \\
\text { instruction that is responsive to students' } \\
\text { cultural differences }\end{array}$ & $\begin{array}{l}\text { Doorn \& Schumm } \\
\text { (2013) } \\
\text { Kolano \& King (2015) } \\
\text { Mantero \& McVicker } \\
\text { (2006) } \\
\text { Pettit (2011) } \\
\text { Sas (2009) } \\
\text { Walker, Shafer, \& Iiams } \\
\text { (2004) } \\
\text { Wong, Indiatsi, \& Wong } \\
\text { (2016) }\end{array}$ \\
\hline 23 & 78 & $\begin{array}{l}\text { Teachers lack awareness about English } \\
\text { Learners }\end{array}$ & $\begin{array}{l}\text { Kolano \& King (2015) } \\
\text { Markos (2012) }\end{array}$ \\
\hline 24 & $\begin{array}{l}79 \\
80\end{array}$ & $\begin{array}{l}\text { Majority of English Learners speak Spanish } \\
\text { and come from Mexico } \\
\text { English Learners from Spanish-speaking } \\
\text { countries tend to be more difficult to work with } \\
\text { than students from European countries; }\end{array}$ & Markos (2012) \\
\hline
\end{tabular}

(Table Continues) 
Table 1. Continued

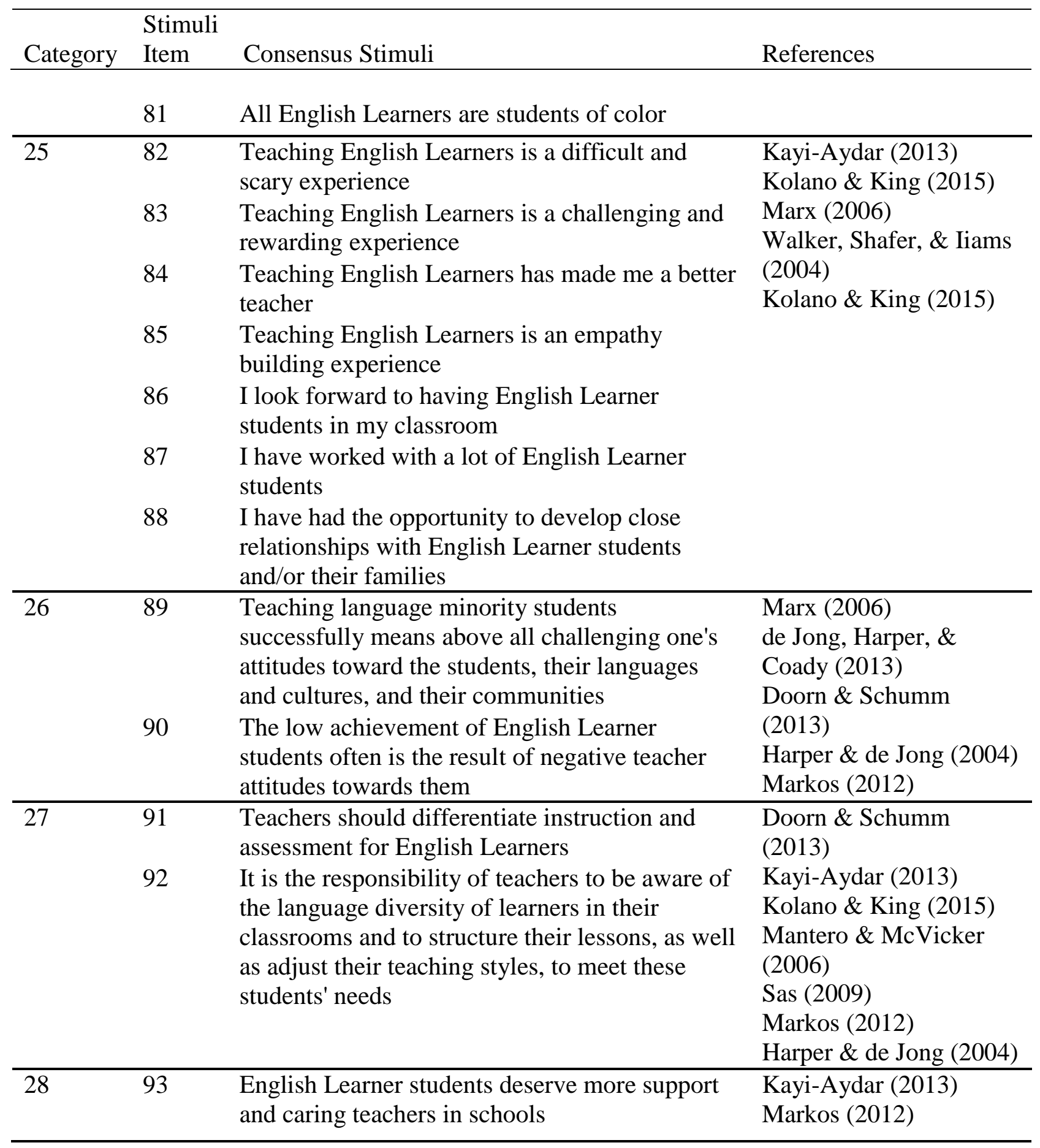




\section{Factors Influencing Teachers' Perceptions of English Learners}

In trying to understand comprehensively teachers' perceptions of English Learners, studies have also examined the possible predictors that influence teachers' attitudes and perceptions (Mantero \& McVicker, 2006; Sas, 2009; Youngs \& Youngs, 2001). Factors that have been found to influence teachers' perceptions include their demographics. For example, Marx (2002/2009) found that pre-service teachers' perceptions varied significantly based on their racial background (White vs. Hispanic). Sas (2009) also found that teachers' perceptions are influenced by factors such as gender, number of spoken languages, and experience with English Learners. Other factors that have been identified as having a positive influence on teachers' perceptions include years of teaching experience, undergraduate and graduate courses related to English Learners, and training related to English Learners (Mantero \& McVicker, 2006). Youngs and Youngs (2001) also found five predictors that influence teachers' perceptions: general educational experiences, English Language Learner training, personal experience with foreign cultures, and contact with English Learner students, and demographic characteristics. Teachers' perceptions and attitudes were positively influenced when they have taken a foreign language course in college, a multicultural education college course, receive staff development training about English Learners, and had prior experience living outside the United States.

\section{Deconstructing Deficit-Based Perceptions}

...the majority of those who enter teacher education are from the dominant group, they may or may not be in tune with the plight of those who do not have access to the same cultural capital. Therefore, teacher educators must seek out unique clinical experience sites that will challenge preservice teachers to redefine their definition of diversity and teaching. (Miller \& Mikulec, 2014, p. 23) 
Research has emphasized the critical importance of deconstructing deficit-based perceptions, which can be accomplished through exposure to counter-narratives, training, cultural immersion or plunge, guided reflection, and courses taught from a critical race theory perspective (Fránquiz et al., 2011; Gonzalez \& Ayala-Alcantar, 2008; Kolano \& King, 2015; Markos, 2012; Ortiz, 2011). Teachers' perceptions may be changed through experiences that encourage the development of a critical pedagogy or a critical caring praxis, both of which are rooted in Critical Race Theory or Latinx Critical Theory (Carjuzaa, 2007; Fránquiz et al., 2011; Gonzalez \& Ayala-Alcantar, 2008; Ortiz, 2011). When teachers develop a critical caring praxis, they "care about students as individuals and critically look at the institutional structures that affect them" (Ortiz, 2011, p. 55). This perspective facilitates the development of a critical consciousness, or the development of a critical awareness of systems of privilege and oppression that perpetuate educational inequities for marginalized-oppressed students, such as English Learners.

\section{The Present Study}

The extant research has identified the significant implications and importance of continuing to investigate teachers' perceptions of English Learners. An examination of the extant literature also suggests a plethora of categories of representative statements related to these perceptions, which raises the question of whether there are inherent perceptual dimensions that may account for teachers' perceptions of English Learners and, if so, what do these perceptual dimensions represent. To investigate these perceptual dimensions, the present study has been designed not only to explore the various perceptual dimensions that may be employed by teachers as they consider English Learners but also to identify potential individual differences among teachers in terms of differential salience of each dimension. Both pre-service and in- 
service teachers' perceptions towards English Learners will be examined through a card-sorting task that will be analyzed using Non-Metric Multidimensional Scaling (NMDS) techniques. In addition, teachers will also complete a demographic questionnaire and a Critical Consciousness Scale.

The stimuli in the card-sorting task were developed from the extant literature to be broadly representative of teachers' perceptions of English Learners. The participants will be asked to sort the stimuli into groups of similar statements, and the co-occurrence of stimuli within groups across participants will characterize the degree of similarity of the stimuli, and the inter-stimuli similarity data will be analyzed with NMDS to reveal underlying perceptual dimensions. Card-sorting tasks hold the advantages of "ease of administration, low susceptibility to experimental demand characteristics, and economy in handling large numbers of objects or stimuli" (Whaley \& Longoria, 2009, p. 105). Card-sorting tasks are used to assess the pairwise similarity of stimuli by having participants attend and sort the stimuli without requiring them to rate the degree of similarity of each possible pair. Thus, with even modest numbers of stimuli, pairwise comparison methods quickly become untenable with undue fatigue and resource demands of the participants. Further, unlike factor analytic methodology, the similarity of the stimuli does not require assessing each stimulus statement in terms of a priori characteristics, such as using a Likert scale to rate agreement with each stimulus statement or to rate veracity of each stimulus statement, etcetera. Previous research with teachers' perceptions of English Learners has required participants to rate the degree to which participants agree with various statements (e.g., Doorn \& Schuum, 2013; Mantero \& McVicker, 2006; Ortiz, 2011; Sas, 2009; Walker et al., 2004; Wong, Indiatsi, \& Wong, 2016) whereas card sorting tasks make no a priori assumptions about the nature or interpretation of the salient dimensions that account for teachers' 
perceptions as similarity is inferred directly through group co-occurrence in the sorting task without reference to presumed perceptual characteristics or dimensions. Thus, the card sorting task should reduce social desirability and uncover participants' implicit perceptions.

Data from card-sorting tasks will be analyzed through Non-Metric Multidimensional Scaling (NMDS) techniques. These analysis techniques have been used in particular in social psychology studies to confirm hypotheses about hidden structures (Pecho, 2017; Whaley \& Longoria, 2009). This method has also been used to reveal underlying perceptual dimensions from participants' responses while preventing contamination from the researchers' preconceptions (Pecho, 2017; Whaley \& Longoria, 2009). MDS and NMDS use proximity data for analysis, meaning that data is "converted into a matrix of proximities [that are used to determine] a geometric configuration (or map of points) in $n$-dimensional space and uncovers meaningful categories encompassing the semantic relations in the proximity data (i.e., the participants' card sorts)" (Whaley \& Longoria, 2009, p. 111). In other words, a cognitive map, known as the stimulus configuration, is derived such that distances in the configuration are as consistent as possible with the similarity data; thus, this configuration serves as a visual representation of the dimensions that explain participants' perceptions of the stimuli. It is important to note that the similarity data is rescaled using a linear transformation so that the rescaled data represent dissimilarity values to make those values commensurate with distances in the configuration. Additionally, NMDS techniques include individual differences approaches to scaling in which each participant or each group of participants have dimension weights that are estimated to explain their individual or group data more effectively by estimating differential weights (i.e., salience) of each dimension. 
Therefore, the overarching goal of this study is to examine cognitive maps of teacher perceptions of English Learners and identify individual differences between participants or groups of participants in terms of the degree to which they attend to each dimension in performing the sorting task, specifically in terms of their demographic characteristics and critical consciousness.

Prior studies have used similar tasks and analysis that support the use of NMDS in the current study (Green \& Manzi, 2002; Pecho, 2017). The first study used a card-sorting task to study racial perceptions and stereotypes. Findings indicated underlying cognitive structures of stimuli associated with Black individuals, as well as subgrouping. Pecho's (2017) dissertation study examined teachers' perceptions of immigrants using NMDS and a card-sorting task. Those findings support the use of card-sorting and MDS as methods and data analysis when attempting to assess perceptual dimensions employed by teachers.

Given the utility and effectiveness of card-sorting task to assess underlying perceptual dimensions, the current study will use a card-sorting and NMDS analysis to explore structures hidden in the sorting data. It is important to note that the goals for this study do not reflect traditional theory testing with a priori hypotheses (e.g., examining predicted group differences with null hypothesis significance testing), even though the development of stimulus statements were guided by a critical pedagogy framework, Critical Race Theory (CRT), and Latinx Critical Theory. These theoretical frameworks focus on deconstructing majoritarian tales, as well as considering the intersection of race, law, and power. The following research questions guide the current study:

1. What are the underlying perceptual dimensions and structures of English Learners held by pre-service and in-service teachers? 
2. What are the factors that influence these perceptual dimensions?

3. What is the influence of teachers' having a Critical Consciousness on their perceptions of English Learners? 


\section{CHAPTER III: RESEARCH DESIGN}

\section{Participants}

Participants were recruited from a public State University that is considered a Historically White Institution (HWI) and a school district in Illinois. The recruited sample for the present study include pre-service teachers $(N=20)$ and in-service teachers $(N=20)$. Participants were grouped into pre-service teachers which included individuals that were in a teaching education program that prepares undergraduate students for the teaching force. In-service participants included teachers that had graduated from a teaching program and had been working in the schools. Considering that the primary analytic techniques, Non-metric Multidimensional Scale (NMDS) are focused on deriving a configuration and not on null hypothesis significance testing, the population size is not required to be extensively large considering the methodology and data analysis for this current study. Thus a minimum of 20 participants for each group was sufficient and 30 is considered to be more than ideal (see Rodgers, 1991).

Pre-service teachers was comprised of individuals ages 19 to $32(\mathrm{M}=21.70, S D= \pm$ $3.01)$, and in-service teacher comprised of individual ages 24 to $58(\mathrm{M}=39.25, S D= \pm 11.50)$. Pre-service teachers also comprised of 14 Females and 6 Males, and in-service teachers comprised of 16 Females and 4 Males. Participants were also asked to provide a race and ethnicity, which was unclear for many to differentiate. For purposes of analyses, individuals were grouped into a Person of Color (POC) or White according to their responses on both the race and ethnicity item. Pre-service participants comprised a majority of White $(N=13,65 \%)$ teachers. This group of pre-service teachers also included seven teachers (35\%) who identify as belonging to an ethnic or racial underrepresented group (Hispanic/Latinx, Black/African American, and Asian/Pacific Islander, Native American, etc.). In-service teachers also included 
mostly teachers who identify as White $(N=16,80 \%)$. This group of in-service teachers also included four teachers $(20 \%)$ who identified as belonging to an ethnic or racial underrepresented group. Across all participants, both pre-service and in-service there were a total of 10 individuals (25\%) that could be identified as a Person of Color (POC). This group of POC, also included three individuals that self-identified as "White" under the category of Race, but were still considered a POC due to their responses on the ethnicity item.

\section{Materials}

\section{Stimuli for Card-Sorting Task}

The stimuli for the current study were developed from the existing literature on teachers' attitudes, perceptions, beliefs, misconceptions, misperceptions towards English Learners. I examined the existing literature and coded the perceptions, which included quotations, facts, statements, common misperceptions, or myths. A total of approximately 400 individual statements were obtained from the extant literature. These statements were initially arranged into two separate, broad lists, one for deficit-based statements and the other for asset-based statements. Each statement was given a brief label to identify what it was addressing, for example, personality, intelligence, racism, immigration, culture, family, etc. Statements were then arranged into categories to identify similar or overlapping perceptions. I then developed consensus wording from the statements in each category. These consensus statements reflected the common themes of statements within each category and served as the stimuli for the card sorting task. These proposed stimuli were reviewed and approved by the co-chairs of my committee for validation and consensus. I developed a total of 28 categories that included statements from both deficit-based and asset-based perceptions. Across these 28 categories, a total of 93 stimuli items were developed to depict perceptions towards English Learners that 
were to be used for the card-sorting task. Each stimuli item was worded in common structure and format to diminish variability due to the format of the items. Each item was printed on a $3 \times 5$ index card.

\section{Demographics and Background Questionnaire}

Participants completed a questionnaire package where they reported their demographic characteristics: age, gender, race, ethnicity, level of education, and education program. They also reported to the investigator if they were in-service or pre-service teachers (see Appendix A). Data were also collected on other background factors that have been indicative in the extant literature to be possible influential factors towards teachers' perceptions (Mantero \& McVicker, 2006; Marx, 2002/2009; Sas, 2009; Youngs \& Youngs, 2001). The questionnaire items included years of teaching experience, the number of languages fluency, experiencing learning a second language, undergraduate courses focused on English Learners, professional development and training focused on English Learners, experience with English Learners, and frequency of contact to English Learners. In addition to assessing the experience or contact teachers have had with English Learners, it was important to consider teachers' exposure to English Learners, either through their own educational experiences or in their teaching classrooms. Therefore, we included questionnaire items such as number of English Learners taught over the course of their careers. Data gathered from this questionnaire was used to find patterns across participants' that influence their perceptions towards English Learners.

\section{Truthfulness Stimuli Likert Rating Scale}

The current study measured explicit perceptions by having participants rate 93 stimuli items on a 7-point Likert scale that ranged from completely false (1) to completely true (7). This aspect of the questionnaire intended to measure teachers' degree of agreement with each stimuli 
item (see Appendix D), and it is important to note that these ratings were performed after the sorting task was completed. Participants also completed item \#34 but it was omitted in data analyses given that it was a repeated statement of item 32 .

\section{Critical Consciousness Scale}

The extant literature emphasizes that teachers' perceptions are influenced by their degree of critical consciousness. Therefore, researchers have recommended that teachers develop a critical consciousness by being exposed to critical pedagogy or critical care praxis (Carjuzaa, 2007; Fránquiz et al., 2011; Ortiz, 2011) to deconstruct internalized majoritarian tales or deficitbased perceptions of English Learners. Given the importance of critical consciousness, the current study will measure teacher participants' critical consciousness with the use of a 22-item Critical Consciousness Scale (CCS; Diemer, Rapa, Park, \& Perry, 2017; see Appendix E). This scale is composed of three subscales: (1) Critical Reflection: Perceived Inequality, (2) Critical Reflection: Egalitarianism, (3) Critical Action: Sociopolitical Participation. The first subscale measures' participants' consciousness to socioeconomic, racial/ethnic, and gendered constraints on educational and occupational opportunity. The second subscale measures participants' endorsement to societal equality or all groups treated as equals, within society. The third subscale measures participants' engagement in social and political activities to change the perceived inequalities. Higher scores on each subscale indicate a greater critical reflection or critical action. This 22-item scale, CCS, was developed and proven to hold validity after an exploratory factor analysis study by Diemer and colleagues (2017) found that the three subscales are internally consistent, with a Cronbach's alpha estimate of .90 (Critical Reflection: Perceived Inequality), .88 (Critical Reflection; Egalitarianism) and .85 (Critical Action: Sociopolitical Participation). The exploratory factor analysis was cross-validated by a confirmatory factor 
analysis, which found a Cronbach's alpha estimate of .89 (Critical Reflection: Perceived Inequality), .87 (Critical Reflection; Egalitarianism) and .76 (Critical Action: Sociopolitical Participation). These studies provide evidence that the 22-item scale has a strong model fit and high estimate of internal consistency. Despite, the supporting evidence for the use of CCS, the modest sample sizes needed for NMDS preclude assessing reliability or validity per se with the current study's sample.

\section{Procedure}

All participants completed the tasks individually in a private quiet room. The tasks were administered by a white-female/European descent researcher assistant and a Chicana/Mexican descent co-principal investigator. The Co-Principal investigator trained the research assistant on the procedure of the study. The study initiated by explaining to participants that the purpose of the current study is to investigate the characteristics among English Learners or students they may potentially have in their classroom. Participants were provided a hard-copy consent form, and assigned a random 4-digit ID number to complete all following tasks. Participants completed the demographic questionnaire, card-sorting task, and the questionnaire packet (i.e., Truthfulness Stimuli Likert Rating Scale and the Critical Consciousness Scale). This sequence was selected as to avoid priming effects from the questionnaires that might influence the card-sorting task. Participants' were then given a $\$ 25$ visa gift card for their participation in the study and their random 4-digit ID number was written in a Log that was turned into the University for Grant Reimbursement Purposes.

\section{Card-Sorting Practice}

Participants were provided a trial to practice the card-sorting task to demonstrate understanding of the task. The researcher assistant or Co-PI read the study's instructions to the 
participants and provide them with nine laminated cards (see Appendix B) to sort based on similarities. Once participants indicated an understanding of sorting cards through the practice trail, participants were then instructed to sort the stimuli items of perceptions towards English Learners. Both the practice trial and card sorting task were timed for research purposes and participants were explained that they could take as long as needed to complete the task.

\section{Card-Sorting Task}

The researcher assistant and/or Co-PI provided participants with standardized instructions and explained that they were to sort the 92 stimuli cards into piles to create conceptually similar piles (see Appendix C). The instructions also included a reminder to focus on sorting the cards on similarity, and not the degree of agreement or disagreement with each stimuli item. They were also reminded that there was no right or wrong way of sorting the cards. After participants indicated they were done sorting the cards into piles, they were instructed to bind each pile with a rubber band. Each participant was also be provided with several sticky-notes and instructed to label each pile. The participants were then asked if they were satisfied with their sorting and labeling and were be provided with an opportunity to re-sort any stimuli items they were not satisfied with. The purpose of the card-sorting task was to have participants tie stimuli items together to indicate the underlying perceptual constructs of English Learners.

\section{Questionnaire Packet}

After participants completed the card-sorting task, they were asked to complete a Likert rating scale questionnaire on the Truthfulness of each stimuli item (see Appendix D) and a Critical Consciousness Scale (CCS; see Appendix E). The questions about the stimuli required participants to rate the items on a 7-point Likert scale. The CCS was used to measure 
participants' consciousness in relation to critical reflection on perceived inequality, critical reflection on egalitarianism, and their critical action on sociopolitical participation.

\section{Data Entry}

Data was entered and analyzed according to the guidelines presented by Whaley and Longoria (2009) as well as a prior dissertation study by Pecho (2017). For each participant, data from the demographic questionnaire, card sorting task, Truthfulness Likert Rating Scale, and Critical Consciousness Scale were initially entered into Excel and transferred into SPSS for data analyses purposes. Participants' data was entered with correspondence to their assigned random 4-digit number and a code of 001 to 020 for pre-service participants and 021 to 040 for in-service participants. The card sorting data required pre-processing to construct a co-occurrence matrix for each participant where stimuli represent both rows and columns and where a value of 1 indicates that the row and column stimulus pair was placed in the same pile and 0 otherwise (see Figure 1). These co-occurrence matrices were then summed across all participants or across the in-service and pre-service teacher training groups so that each similarity value represents the number of participants who co-classified each pair of stimuli together. For more details see, Whaley and Longoria (2009).

\section{Supporting Research}

Whaley and Longoria (2009) indicate that prior studies have used MDS and card sorting. These studies indicated the heuristic value of using MDS as a statistical technique as well as the effectiveness of using a card sorting task methodology. Existing research has indicated that card sorting tasks "may be superior to or, at minimum, equally effective as other methods of data collection for MDS" (p. 109). 


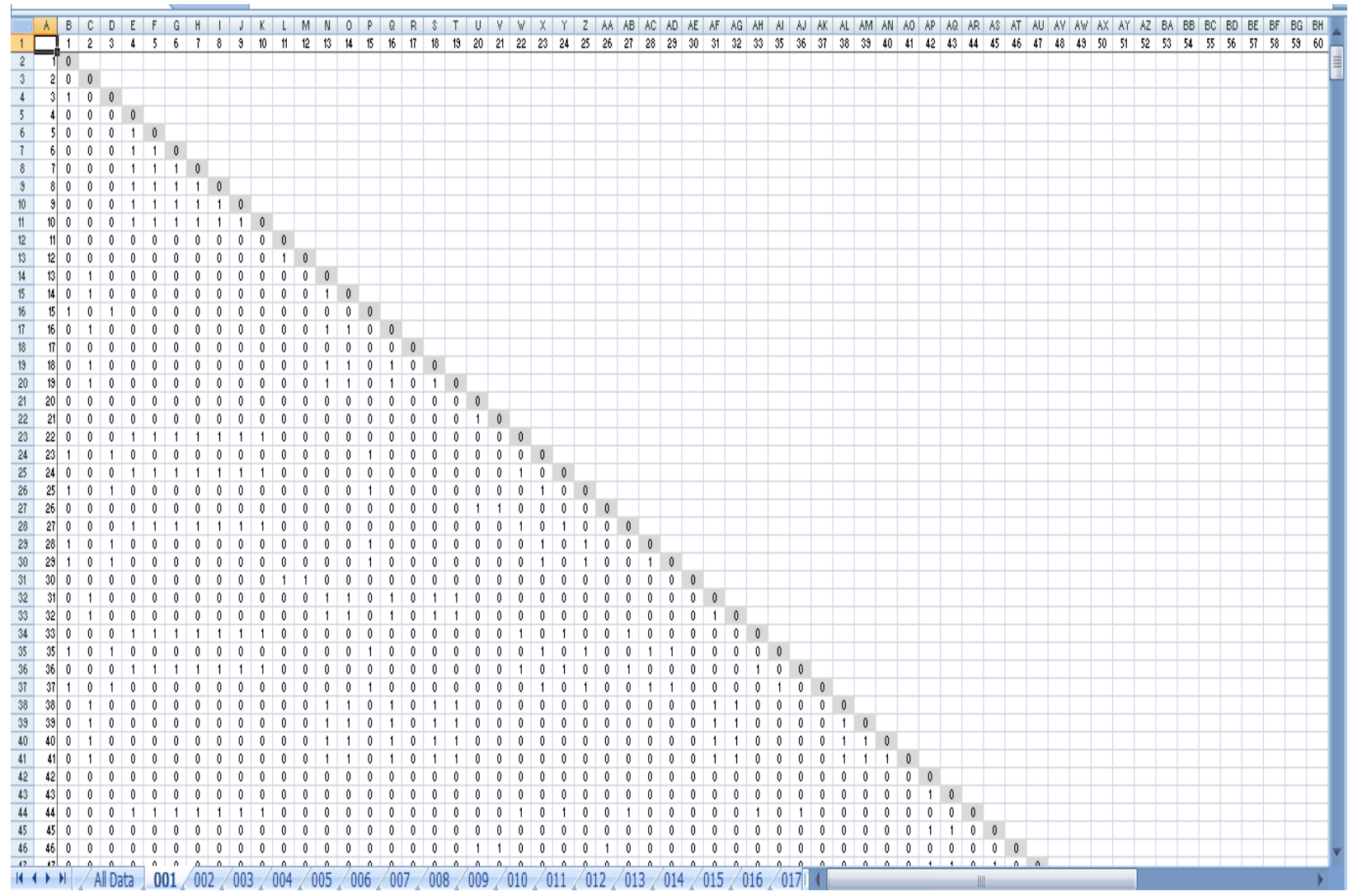

Figure 1. Example of participant 001 similarity ratings of 93 items with item 34 deleted.

Whaley and Longoria (2009) emphasized the advantages these studies have highlighted about MDS, such as MDS allows for dimensional comparisons in the data across different groups. Another advantage is the practicality in that the technique allows for different levels of measurements, such as interval, ordinal, and nominal data, to be analyzed. Related to this current study and topic, a prior study by Green and Manzi (2002) investigated racial stereotypes and perceptions associated to Black individuals. This study found that MDS was a stronger statistical technique given that it revealed the complexity of the data and underlying subgroups. Therefore, another advantage that MDS holds is that it reveals the subgroups and complexity of data that may be hidden or undiscovered with the use of other analysis. Thus, MDS has been indicative to 
be a useful technique for studying "participants" thinking or decision-making process" (Whaley \& Longoria, 2009, p. 109).

\section{Data Analysis}

MDS is a class of exploratory data analysis techniques that condense large amounts of data into a spatial map to represent visually the dissimilarities and similarities among stimuli items (Jaworska \& Chupetlovska-Anastasova, 2009). At the same time, MDS also allows one to analyze data with different levels of measurements, such as interval, ordinal, and nominal data. Whaley and Longoria (2009) explain that the measurement level of data influences the type of MDS analysis technique. Metric MDS is used with interval level data, whereas nonmetric MDS is used with ordinal and nominal level data. Non-metric MDS will be used in the current study given the use of card-sorting task with ordinal level data.

Literature about MDS explains that there are three different models each producing a different outcome (Giguère, 2006). These three models include, Classical MDS (CMDS), Replicated MDS (RMDS), and Weighted MDS (WMDS). Weighted MDS is also known as Individual differences scaling. The first step in analysis will be to conduct a classic non-metric MDS analysis without differentiating by subgroup. Subsequently, individual differences NMDS will be used to compare the in-service and pre-service teachers' perceptions by examining similarity matrices aggregated within each group. Finally, individual differences NMDS will be attempted to compare each individual's perceptions without any aggregation of co-occurrence matrices. This last analysis, however, may not produce interpretable results due to the binary nature of the data. This outcome was also supported in a previous study by Pecho (2017) that used similar methodology and data analyses. Thus, the second modeling endeavor is expected to be the most appropriate for the current study due to the interested in examining individual 
differences among participants, thus Weighted MDS (WMDS) was used for the current study. WMDS is also explained to provide a stimulus space and a participant's space, which "indicate the differential weighting given to dimensions in the common stimulus spaces by each participant, and the models fit to each participants data" (Giguère, 2006, p. 31).

\section{Interpreting NMDS Output}

MDS produces a cumulative matrix that is comprised of all the individual matrices of the 40 participants in this study. This matrix was converted into a geometric configuration with an $n$ dimensional space (i.e., cognitive map), referred to as a MDS solution. The MDS solution with the most interpretable solution was found by analyzing the measures of fit: $R^{2}$ and Kruskal's stress index (Giguère, 2006; Whaley \& Longoria, 2009) to find the most optimal MDS solution. The first measure of fit, $R^{2}$ measures the 'goodness of fit' indicating the amount of variance that is explained by the $n$-dimensional configuration. Therefore, higher $R^{2}$ suggest a better fit. The second measure of fit, Kruskal's stress index measures the 'badness of fit,' in relation to the produced $n$-dimensional configuration. A smaller Kruskal's stress index value indicates a better fit. According to Kruskal and Wish (1978) a stress value should be at least $<0.15$ and preferably $\leq 0.10$.

The dimensions in NMDS were interpreted by examining the configuration of stimuli and contrasting stimuli with coordinates located at the extremes of each dimension. One complication in interpreting NMDS dimensions in classical scaling models is that the configurations may be rotated arbitrarily in Euclidean space without degrading the degree of fit, as measured by S-Stress, between the configuration and the dissimilarity data. Because distances between points in the configuration represent dissimilarities, orthogonal rotation of the dimensions will not change the distances between each pair of stimulus points, but these 
rotations will change the coordinates of each stimulus. Thus, the interpretation of the dimensions involves reviewing the configuration per se to identify interpretable directions or vectors. Rotated coordinates may then be used to contrast stimuli at opposing ends of the rotated dimension for interpretation.

With individual differences NMDS, the geometric orientation of each dimension in the group or common configuration is non-arbitrary in that each dimension is weighted for each source of data. Thus, the configuration is determined to optimize the congruence of weighted distances of stimulus pairs to each sources' dissimilarity data. The weights for each source on each dimension, therefore, represent salience of that particular dimension to the given source of data, which can be modeled as either a sub-group or an individual, as mentioned above.

\section{Dimension Interpretation}

After the optimal MDS solution was found considering the 'goodness of fit' measures, there was an n-dimensional solution that was selected for interpretation. Interpreting the dimensions involved inspecting the stimuli items with their dimension weights that were produced in the configuration for the optional $n$-dimensional MDS configuration. In addition to visually inspecting the stimuli and the clusters of data, this current study also used correlational and multivariate analyses for interpreting the dimensions that teachers attend to when perceiving English Learners.

\section{Examining Group Differences}

Previous studies have indicated various factors that appear to impact teachers' perceptions towards English Learners. To analyze these group differences, subject weights were used to find the importance of each dimension to each subgroup. This current study examined group differences based on teaching status (Pre-service teacher vs. In-service teacher). 


\section{CHAPTER IV: RESULTS}

The purposes of this study were to use a more quantitative methodology that has not been previously used, such as MDS, to (1) examine teachers' perceptions towards English Learners, by finding the underlying perceptual dimensions held by pre-service and in-service teachers (2) identify the factors (i.e., individual differences from demographic questionnaire) that influence these perceptual dimensions, and (3) find the influence of teachers' having a Critical Consciousness on their perceptions of English Learners.

\section{Card-Sorting Variables: Number of Piles, Labels, and Sorting Time}

Perceptions towards English Learners were examined using MDS analyses to uncover the underlying dimensions. These underlying dimensions were a result of a card-sorting task that involved analyzing the similarity ratings across all 40 participants, as well as between pre-service vs. in-service teachers. Additional variables were also gathered from each participant from the card-sorting task, such as the number of piles created by participants and the labels provided to the piles. Table 2 provides the frequencies for the number of piles created across all 40 participants $(\mathrm{M}=6.78, S D= \pm 4.39)$ from the card-sorting task. Creating three piles was the most common among participants, accounting for $27.5 \%$.

When analyzing the piles based on education status of being a pre-service teacher or inservice teacher, it can be noted that there are some differences between both groups in regards to the numbers of piles created in the card-sorting task. Table 3 provides frequencies for the number of piles created among pre-service teachers $(\mathrm{M}=5.85, S D= \pm 4.18)$ and in-service teachers $(\mathrm{M}=$ $7.70, S D= \pm 4.50$ ) in the card-sorting task. Creating three piles was the most common among pre-service teachers $(45 \%)$, and $40 \%$ of pre-service teachers created more than five or more 
piles. Table 3 also includes the frequencies for the number of piles in-service teachers created which varied a lot more with frequencies from 1 to 3 for creating from 2 to 21 piles.

Table 2

Card-Sorting Task Outcomes in All 40 Participants

\begin{tabular}{llcc}
\hline Variable name & Group & Frequency & $\%$ \\
\hline Number of sorted piles & 2 & 1 & $2.5 \%$ \\
3 & 11 & $27.5 \%$ \\
4 & 4 & $10 \%$ \\
5 & 3 & $7.5 \%$ \\
6 & 4 & $10 \%$ \\
7 & 4 & $10 \%$ \\
8 & 3 & $7.5 \%$ \\
9 & 1 & $2.5 \%$ \\
10 & 3 & $7.5 \%$ \\
11 & 2 & $7.5 \%$ \\
13 & 1 & $2.5 \%$ \\
16 & 1 & $2.5 \%$ \\
18 & 1 & $2.5 \%$ \\
21 & 1 & $2.5 \%$ \\
\hline
\end{tabular}

Table 3

Card-Sorting Task Outcomes in Pre-service vs. In-service Participants

\begin{tabular}{llccccc}
\hline \multirow{2}{*}{ Variable name } & \multicolumn{3}{c}{ Pre-service Teachers } & \multicolumn{3}{c}{ In-service Teachers } \\
\cline { 2 - 7 } & Group & Frequency & $\%$ & Group & Frequency & $\%$ \\
\hline Number of sorted piles & 3 & 9 & $45 \%$ & 2 & 1 & $5 \%$ \\
& 4 & 4 & $20 \%$ & 3 & 2 & $10 \%$ \\
& 5 & 1 & $5 \%$ & 4 & 1 & $5 \%$ \\
& 6 & 1 & $5 \%$ & 5 & 2 & $10 \%$ \\
& 7 & 1 & $5 \%$ & 6 & 3 & $15 \%$ \\
& 8 & 1 & $5 \%$ & 7 & 3 & $15 \%$ \\
10 & 1 & $5 \%$ & 8 & 2 & $10 \%$ \\
& 11 & 1 & $5 \%$ & 9 & 1 & $5 \%$ \\
13 & 1 & $5 \%$ & 10 & 2 & $10 \%$ \\
& 18 & 1 & $5 \%$ & 11 & 1 & $5 \%$ \\
& & & & 16 & 1 & $5 \%$ \\
& & & & 21 & 1 & $5 \%$ \\
\hline
\end{tabular}


Data was also gathered on the label names given to each pile. Appendix F provides a list of all the labels given to each pile created by pre-service and in-service teachers along with the duration for the practice-trial and the card-sorting task. Duration for the card-sorting task was rounded to the nearest whole minute to calculate an average duration for the card-sorting task. Duration data on the card-sorting task suggests that Pre-service teachers had an average duration of 14 minutes $(M=14.10, S D=7.06)$ and In-service teachers had an average of 23 minutes $(M=$ 22.50, $S D=12.38$ ), these times were significantly different, $t(38)=-2.64, p=.012$. Pre-service teachers appeared to take less time when sorting the stimuli cards than in-service teachers.

\section{Multidimensional Scaling Analysis with MDSCAL}

A non-metric multidimensional scaling analysis approach of MDSCAL was used to develop cognitive maps of all participants to reflect their perceptions about EL students. Data included a total of 92 statements, with item 34 omitted and deleted due to being a replicate of item 32. The MDSCAL solution provided a data matrix of all the similarity ratings of the 92 item aggregated across all 40 participants. Kruskal's stress index and $R^{2}$ were examined to identify the optimal MDS solution and number of dimensions. An optimal solution requires for the $n$ dimensional configuration to have a small Kruskal's stress index and a high $R^{2}$ value, an optimal solution would include a stress value of at least $<0.15$ and preferably $\leq 0.10$ (Kruskal \& Wish, 1978). Table 4 includes the stress index and $R^{2}$ values for each potential solution from six through two dimensions. Through examining each of these values, a solution with 3 dimensions is considered optimal due to having the most acceptable stress index and $R^{2}$ values. 
Table 4

MDSCAL: Stress and $R^{2}$ Values for Dimensions 6-2

\begin{tabular}{ccc}
\hline $\begin{array}{c}\text { Number of } \\
\text { dimensions }\end{array}$ & Stress & $R^{2}$ \\
\hline 6 & 0.059 & 0.977 \\
5 & 0.067 & 0.972 \\
4 & 0.079 & 0.966 \\
3 & 0.094 & 0.958 \\
2 & 0.144 & 0.919 \\
\hline
\end{tabular}

\section{Dimension Interpretation}

MDSCAL data produced a 3-dimensional configuration, as represented in Figure 2, which represents the visual mapping of all 92 statements sorted and aggregated across all 40 participants.

\section{Derived Stimulus Configuration}

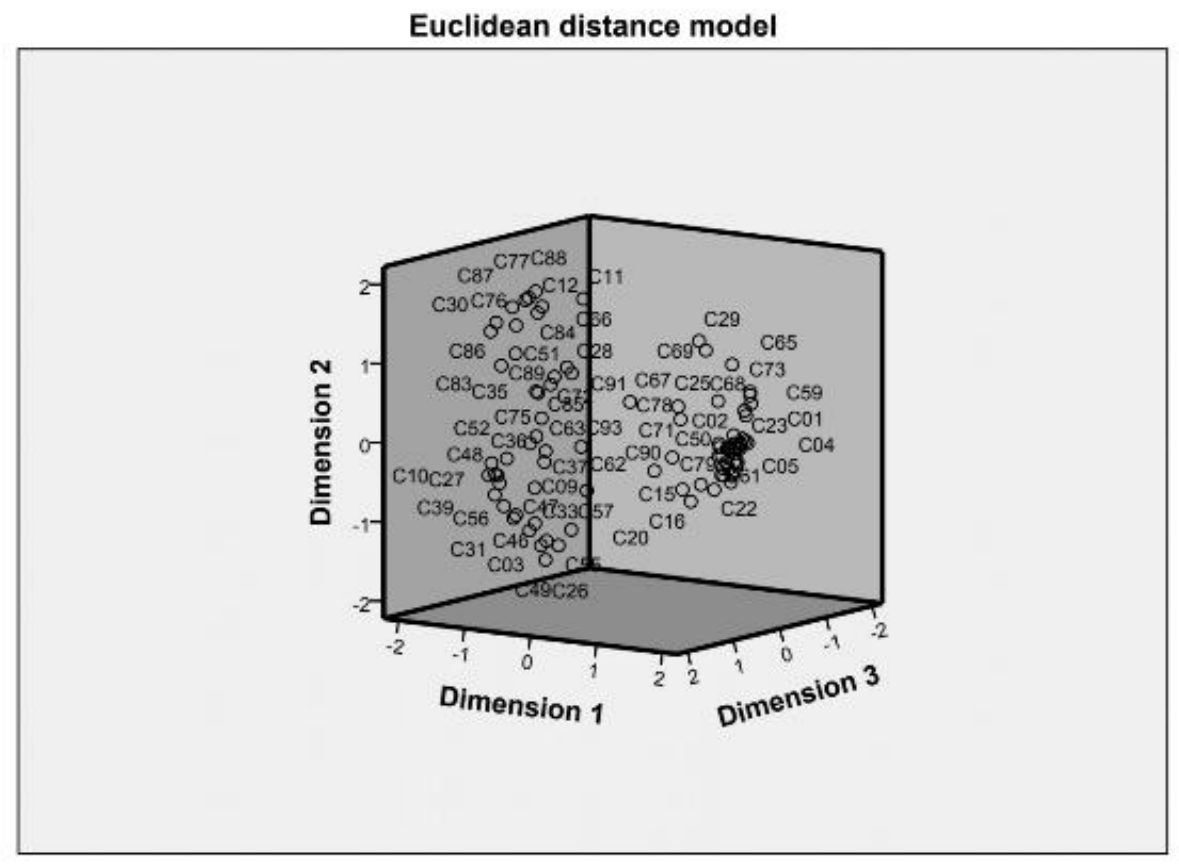

Figure 2. Stimulus configuration derived in three dimensions. 
Each dimension is composed of cards that were sorted and perceived most similar to each other producing a group space. These group configurations produced a 3-dimensional solution that was interpreted through a visual sorting using the statements and their configuration values. Statements were sorted from smallest to largest configuration values producing two extremes of each dimension. Statements at each extreme of the dimension were analyzed and interpreted according to their shared content and thematic similarities.

MDSCAL dimension 1: Positive vs. negative statements. Dimension 1 had statements that ranged from configuration value of -1.898 to 1.666 (see Appendix G) where participants perceived the stimuli items being positive to negative statements about English Learners. On the positive end of the dimension, it included Card \#35 with the statement of, "It is important for mainstream teachers to understand and know how English Learner parents' view schools and learning." On the negative end of the dimension, it included Card \#64 with the statements of, "English Learners are aggressive; I would worry for my safety in teaching in a school with a lot of English Learners."

These two ends on dimension 1 indicated that across all 40 participants, their perceptions were heavily influenced whether they perceived a statement to be positive or negative. Statements that were on the positive end (i.e., statements with a negative loading on the dimension or negative configuration value) all shared the commonality of being positive statements about English Learners' culture, instructional needs, experience teaching them, inclusion into the classroom, achievement and expectations, intelligence, and language skills. On negative end (i.e., statements with a positive loading on the dimension or positive configuration value) all shared the commonality of being negative statements about English Learners. These statements came from the categories such as Fear of English Learners, Segregation \& Lack of 
Support, Immigration, Assimilation, Intelligence, Parents Influence, Personality \& Behavior, Culture Influence, etc. These statements included perceptions of English Learners as aggressive, illegal immigrants, being poor, needed to assimilate, very low achievement and expectations, lower intelligence, parents not caring, or being "at-risk".

MDSCAL dimension 2: Student statements vs. teacher statements. Dimension 2 was comprised of statements that ranged from configuration values of -1.521 to 1.807 (see Appendix H) where participants perceived the stimuli items to be statements about students (i.e., English Learners) or statements about Teachers. One end of the dimension was comprised of Student statements, such as Card \#26 with the statement of, "English Learner students are more motivated to succeed than many of their native English-speaking peers." In contrast, the other end of the dimension included Card \#11 with the statement of, "I feel more comfortable working with English Learners than other minority students."

These two ends on dimension 2 indicated that across all 40 participants their perceptions were heavily influenced whether they perceived a statement to be either about students (i.e., English Learners) or to be about teachers. Statements that were on the About Students end (i.e., statements with a negative loading on the dimension or negative configuration value) all shared the commonality of being about English Learners and started with "English Learners....", whereas statements that were on the About Teachers end (i.e., statements with a positive loading on the dimension or positive configuration value) all shared the commonality of starting with "I...." and directly related to teachers.

MDSCAL dimension 3: Systemic barriers vs. resources. Dimension 3 has statements that ranged from configuration values of -1.706 to 1.267 (see Appendix I) where participants perceived the stimuli items to range from barriers encountered when working with English 
Learners to assets or resources that English Learners bring with them. The Systemic Barriers end of the dimension included Card \#78 with the statement, "Teachers lack awareness about English Learners", whereas the Resources end of the dimension included Card \#39 with the statement, "English Learners' parents want their children to learn English and/or be bilingual."

Interpreting Dimension 3 was less straightforward than interpreting Dimensions 1 and 2. However, the stimuli items on the Systemic Barriers end of the Dimension (i.e., statements with a negative loading on the dimension or negative configuration value) all shared the commonality of being systemic barriers that teacher encounter related to being held accountable for ELs achievement, providing an equitable education, responsibilities in teaching, training needs, and importance of understanding ELs experiences. The cards on the Resources end of the dimension (i.e., statements with a positive loading on the dimension or positive configuration value) all shared the commonality of reflecting stimuli content related to things that English Learners bring with them, such as parents with aspirations, unique needs and experiences, language skills, cultural experiences, motivation, knowledge, relationships, positive personality and behavioral traits, intelligence, and positive experiences when working with them.

\section{Individual Differences Scaling Analysis with INDSCAL}

INDSCAL was used to analyze the individual differences across individual participantby-participant data as well as to find subgroup differences among participants status (e.g., preservice vs. in-service).

\section{Participant-by-Participant Differences with INDSCAL}

Generating an INDSCAL solution required an input of 40 data matrices, with each participant's matrix including binary data from their card-sorting task (i.e., values of 1 indicate that a pair of stimuli were sorted in the same pile, whereas values of 0 indicate that a pair of 
stimuli were sorted into different piles). Similar to MDSCAL analyses, INDSCAL also generated stress indices and $R^{2}$ values that were used to identify the optional solution. An ideal solution requires a small stress index and a high $R^{2}$ value, with a stress value of at least $<0.15$ and preferably $\leq 0.10$ (Kruskal $\&$ Wish, 1978). Table 4 provides the stress values and $R^{2}$ values for each potential solution with six to two dimensions.

Examination of these values indicated that as $R^{2}$ values increase the stress index became elevated. Therefore, INDSCAL across all 40 participants did not generate an optimal solution (see Table 5). This produced similar findings in Pecho (2017), who concluded that the data from INDSCAL did not produce favorable data for individual differences across all 40 participants. It was hypothesized that the nature of the sorting data being binary (i.e., $0=$ different pile or $1=$ same pile) did not allow for the necessary sensitivity to explain individual differences across all 40 participants. The lack of acceptable stress and $R^{2}$ values in this study led to supporting this same hypothesis.

Table 5

INDSCAL: Stress and $R^{2}$ Values for Dimensions 6-2

\begin{tabular}{ccc}
\hline $\begin{array}{c}\text { Number of } \\
\text { dimensions }\end{array}$ & Stress & $R^{2}$ \\
\hline 6 & 0.239 & 0.18 \\
5 & 0.271 & 0.19 \\
4 & 0.296 & 0.27 \\
3 & 0.336 & 0.22 \\
2 & 0.443 & 0.22 \\
\hline
\end{tabular}

A Pearson product-moment correlation coefficient was computed to assess if the 3 dimensions generated through INDSCAL across all 40 participants were correlated to the 3 dimensions from MDSCAL analysis. There were no consistent patterns to the correlations between the dimensions from MDSCAL and INDSCAL by participant (see Table 6). 
Table 6

Correlations between MDSCAL Dimensions and INDSCAL Dimensions

\begin{tabular}{lccc}
\hline & \multicolumn{3}{c}{ INDSCAL Participant-By-Participant Dimensions } \\
\cline { 2 - 4 } & Dim 1 & Dim 2 & Dim 3 \\
\hline MDS Dimension 1 & -.204 & $.446^{* *}$ & $.246^{*}$ \\
MDS Dimension 2 & .003 & -.115 & -.149 \\
MDS Dimension 3 & -.020 & .104 & .027 \\
\hline
\end{tabular}

Note. MDS $=$ MDSCAL. $n=92 . * *$ indicated $\mathrm{p}<.01 . *$ indicated $\mathrm{p}<.05$

Pre-Service vs. In-Service Subgroup Differences with INDSCAL

INSCAL was also used to analyze individual differences among participants according to their subgroups (Pre-service teachers vs. In-service teachers). To generate subgroup differences using INDSCAL, individual data matrices (i.e., each participant's matrix with binary data) were aggregated into two groups (i.e., one data matrix for the 20 pre-service teachers and one for the 20 in-service teachers). Similar to MDSCAL analyses, the output generated stress index and $R^{2}$ values to identify the optimal solution. As previous analysis an ideal solution requires a small stress index and a high $R^{2}$ value. Table 7 provides the stress values and $R^{2}$ values for each potential solution with five to two dimensions. Examination of these values indicates that an optimal solution would have 3 dimensions.

Table 7

INDSCAL: Stress and $R^{2}$ Values for Dimensions 5-2

\begin{tabular}{ccc}
\hline $\begin{array}{c}\text { Number of } \\
\text { dimensions }\end{array}$ & Stress & $R^{2}$ \\
\hline 5 & 0.116 & 0.92 \\
4 & 0.160 & 0.86 \\
3 & 0.160 & 0.87 \\
2 & 0.206 & 0.83 \\
\hline
\end{tabular}

INDSCAL generated a solution with 3 dimensions to account for the individual differences across subgroup of Pre-service and In-service teachers. Examination of these three 
dimensions involved the similar process as in MDSCAL of sorting stimuli items with the use of their configuration values and analyzing the stimuli items on the extremes of each dimension. These three dimensions were also compared to the dimensions produced by MDSCAL to notice whether they produced the same constructs.

Correlations: MDSCAL and INDSCAL dimensions. Prior to interpreting each dimension generated from individual differences by subgroups, it was important to analyze the level of similarity across the dimensions from MDSCAL and INDSCAL by subgroup. A Pearson product-moment correlation coefficient was computed to assess the relationship between MDSCAL's 3 dimensions and INDSCAL's 3 dimensions. Results indicated that there was a strong, positive correlation between MDS Dimension 1 and INDSCAL Dimension $1, r=0.98, n$ $=92, p=0.000$. There was also a strong, positive correlation between MDS Dimension 2 and INDSCAL Dimension 2, $r=0.89, n=92, p=0.000$. Finally, there was a strong, positive correlation between MDS Dimension 3 and INDSCAL Dimension 3, $r=0.95, n=92, p=0.000$. These strong, positive correlations between MDSCAL dimensions and INDSCAL dimensions (see Table 8) suggest that the Dimensions across these two analyses consisted of similar constructs. These results were further verified by interpreting the dimensions produced from INDSCAL individual differences by subgroup.

Table 8

Correlations between MDSCAL Dimensions and INDSCAL Subgroup Dimensions

\begin{tabular}{lllc}
\hline & \multicolumn{3}{c}{ INDSCAL Subgroup Dimensions } \\
\cline { 2 - 4 } & Dim 1 & Dim 2 & Dim 3 \\
\hline MDS Dimension 1 & $.979^{* *}$ & $.442^{* *}$ & $-.267^{*}$ \\
MDS Dimension 2 & -.151 & $.894^{* *}$ & .108 \\
MDS Dimension 3 & .059 & -.168 & $.949^{* *}$ \\
\hline
\end{tabular}

Note. MDS $=$ MDSCAL. $n=92 . * *$ indicated $\mathrm{p}<.01 . *$ indicated $\mathrm{p}<.05$ 


\section{Dimension Interpretation}

INDSCAL dimension 1. Dimension 1 generated configuration values from -1.454 to 1.223 (see Appendix J) and indicated that the statements ranged from Positive to Negative statements, similar interpretations to MDSCAL Dimension 1. The Positive statements end of the dimension included Card \#92 with the statement of "It is the responsibility of teachers to be aware of the language diversity of learners in their classrooms and to structure their lessons, as well as adjust their teaching styles, to meet these students' needs." The Negative statements end of the dimension included Card \#32 with the statement of "English Learner students are not exposed to cultural enriching experiences by their families." Examining the stimuli items on each extreme indicated similar positive and negative statements about English Learners. Therefore, Dimension 1 was the same across both MDSCAL and INDSCAL analyses.

INDSCAL dimension 2. Dimension 2 generated configuration values from -2.005 to 1.810 (see Appendix K) and indicated that the statements ranged from Students statements to Teacher statements, with similar interpretations to MDSCAL Dimension 2. The Students statements end of the dimension included Card \#26 with the statement, "English Learner students are more motivated to succeed than many of their native English speaking peers." The Teacher statements end of the dimension included Card \#69 with the statement, "I prefer to teach students from similar background as me." A comparison of the stimuli on the extreme ends of Dimension 2 on INDSCAL configuration had similar patterns to that of Dimension 2 on the MDSCAL configuration. Therefore, Dimension 2 was the same across both MDSCAL and INDSCAL analyses.

INDSCAL dimension 3. Dimension 3 generated configuration values from -2.429 to 1.891 (see Appendix L) and indicated that the statements ranged from Systemic Barriers to 
Resources, similar interpretations to MDSCAL Dimension 3. The Systemic Barriers end of the dimension included Card \#78 with the statement, "Teachers lack awareness about English Learners." The Resources end of the dimension included Card \#47 with the statement, "All students in the United States should learn to speak more than one language.” Dimension 3 on INDSCAL configuration had similar patterns to that of Dimension 3 on MDSCAL configuration, such that it ranged from barriers encountered when working with English Learners to assets or resources that English Learners bring with them. Therefore, Dimension 3 was the same across both MDSCAL and INDSCAL analyses.

\section{Subject Weights Analysis}

Another component that was analyzed was the consideration of subject weights, which measure the importance of each dimension to each subgroup of participants (i.e., Pre-service teachers vs. In-service teachers). Across all three dimensions, Dimension 1 was weighted more strongly by both pre-service and in-service participants (see Table 9). Therefore, both pre-service and in-service teachers attended primarily to whether statements were positive or negative (i.e., Dimension 1: Positive vs. Negative Statements); furthermore, these weights are roughly the same, which suggests that dimension one was equally salient to both groups. After attending to Dimension 1, both pre-service and in-service teachers attended to whether statements were about students or teachers, (i.e., Dimension 2: Student Statements vs. Teacher Statements). When examining Dimension 2 across both subgroups of teachers, it was also noted that they attend to this dimension with roughly equal weights, again suggesting equal salience for Dimension 2. Examination of Dimension 3 (i.e., Systemic Barriers vs. Resources) reveled a difference in subject weights across the subgroups of teachers, such that in-service teachers $($ subject weight $=$ 0.31) attended about two times as much to this dimension in comparison to pre-service teachers 
(subject weight $=.18)$. Dimension 3 was related to Systemic Barriers and Resources teachers' encounter when teaching English Learners

Table 9

Subject Weights on Dimensions 1, 2, and 3 by Teaching Status

\begin{tabular}{lccc}
\hline & \multicolumn{3}{c}{ Subject Weights } \\
\cline { 2 - 4 } Subgroup & Dim. 1 & Dim. 2 & Dim. 3 \\
\hline Pre-service & 0.823 & 0.372 & 0.183 \\
In-service & 0.812 & 0.371 & 0.306 \\
\hline
\end{tabular}

\section{Correlations with Other Factors}

\section{MDSCAL Dimensions, INDSCAL Dimensions, and Truthfulness Ratings}

Participants completed a Truthfulness Likert scale in which they rated the 92 statements from Completely True to Completely False. This measure gathered additional data of teachers' perceptions towards English Learners. A Pearson product-moment correlation coefficient was conducted to examine the relations between the average Truthfulness ratings from pre-service teachers, in-service teachers, and all participants with each dimension identified in MDSCAL and INDSCAL analysis (see Table 10). There was a highly significant positive correlation between the average Truthfulness ratings of pre-service teachers and MDSCAL Dimension 1, $r=$ $0.28, n=92, p=0.006$. There was a highly significant positive correlation between the average Truthfulness ratings of in-service teachers and MDSCAL Dimension 1, $r=0.28, n=92, p=$ 0.007. There was a highly significant positive correlation between the average Truthfulness ratings of all participants/teachers and MDSCAL Dimension 1, $r=0.28, n=92, p=0.006$. Therefore, teachers' average Truthfulness of the 92 stimuli items was related to Dimension 1: Positive vs. Negative Statements. 
Table 10

Correlations between Dimensions and Average Truthfulness Ratings

\begin{tabular}{lccc}
\hline & \multicolumn{2}{c}{ Average Truthfulness Ratings } \\
\cline { 2 - 4 } Analyses Dimension & Pre-service & In-service & All Teachers \\
\hline MDSCAL Dim. 1 & $.282^{* *}$ & $.279^{* *}$ & $.284^{* *}$ \\
MDSCAL Dim. 2 & -.001 & -.039 & -.022 \\
MDSCAL Dim. 3 & .042 & .025 & .033 \\
Subgroup INDSCAL Dim. 1 & $.273^{* *}$ & $.275^{* *}$ & $.278^{* *}$ \\
Subgroup INDSCAL Dim. 2 & .118 & .091 & .105 \\
Subgroup INDSCAL Dim. 3 & -.045 & -.062 & -.055 \\
By Participant INDSCAL Dim. 1 & $-.914^{* *}$ & $-.946^{* *}$ & $-.943^{* *}$ \\
By Participant INDSCAL Dim. 2 & .165 & .192 & .182 \\
By Participant INDSCAL Dim. 3 & $.290^{* *}$ & .133 & $.211^{*}$ \\
\hline
\end{tabular}

Note. $n=92 . * *$ indicated $\mathrm{p}<.01 . *$ indicated $\mathrm{p}<.05$

\section{INDSCAL Dimensions and Critical Consciousness Variables}

Participants also completed a Critical Consciousness Scale (CCS) to measure their consciousness about perceived inequality, egalitarianism, and sociopolitical participation (i.e., CCS subscales). Pearson product-moment correlation coefficients was computed to examine the relation between participants Critical Consciousness and their perceptions towards English Learners based on the card sorting task data across all 40 participants. There were no significant correlations between the three different subscales of the CCS with Dimension 1, 2, or 3 (see Table 11). Therefore, CCS does not explain how people are attending to Dimension 1, 2, or 3. Table 11

Correlations between Critical Consciousness Subscales and Dimensions

\begin{tabular}{lccc}
\hline & \multicolumn{3}{c}{ INDSCAL Dimensions } \\
\cline { 2 - 4 } CCS Subscales & Dim. 1 & Dim. 2 & Dim. 3 \\
\hline Critical Reflection of Perceived Inequality & .047 & -.047 & .077 \\
Critical Reflection of Egalitarianism & .089 & .123 & .103 \\
Critical Action of Sociopolitical Participation & -.230 & -.174 & -.220 \\
\hline
\end{tabular}

Note. $n=92 . * *$ indicated $\mathrm{p}<.01 . *$ indicated $\mathrm{p}<.05$ 
Results did indicate various correlations among the different subscales as summarized in Table 12. Overall, the more a participant perceives inequality the more involved they are in sociopolitical actions, $r=0.368, n=40, p=.020$. Also, the more a participant can perceive inequality the less they endorse in egalitarianism or viewing that all groups are treated as equal within society, $r=-0.274, n=40, p=.087$. And, the more a participant endorsed egalitarianism the less they participated in social and political activities to change perceived inequalities, $r=$ $-0.392, n=40, p=.012$.

Table 12

Correlations across Critical Consciousness Subscales

Sociopolitical

\begin{tabular}{lccc} 
CCS Subscales & Perceived Inequality & Egalitarianism & Participation \\
\hline Perceived Inequality & 1 & -.274 & $.368^{*}$ \\
Egalitarianism & -.274 & 1 & $-.392^{*}$ \\
Sociopolitical Participation & $.368^{*}$ & $-.392^{*}$ & 1 \\
\hline Note $n=40 * *$ indicated $p<.01 *$ indicated $\mathrm{p}<.05$ & &
\end{tabular}

Repeated Measures MANOVAs

Several Repeated Measures MANOVAs were conducted to examine the influence of various factors upon Dimension 1, 2, and 3. These factors were selected based on previous research studies have indicated to impact teachers' perceptions of English Learners (Mantero \& McVicker, 2006; Marx, 2002/2009; Sas, 2009; Youngs \& Youngs, 2001).

\section{Individual Factors Influencing Perceptual Dimensions}

Teaching status. Results revealed that the dimension main effect was highly significant (Wilks' $\Lambda=.15, F[2,37]=106.15, p=.000, \eta_{\mathrm{p}}^{2}=.85$ ); thus, participants were not attending to the dimensions equally based on teaching status (pre-service or in-service). The Dimension by Teaching Status interaction, the effect of interest, was highly significant, $\Lambda=.78, F(2,37)=5.07$, $p=.011, \eta_{\mathrm{p}}^{2}=.22$; the main effect of teaching status was non-significant, $(F[1,38]=0.73$, 
$\left.p=.399, \eta_{\mathrm{p}}^{2}=.019\right)$. The significant interaction between dimensions and status (represented in Figure 3 by lines that are not parallel) suggests that in-service teachers' perceptions and the salience of these perceptions of ELs are significantly different from pre-service teachers' perceptions (see Figure 3).

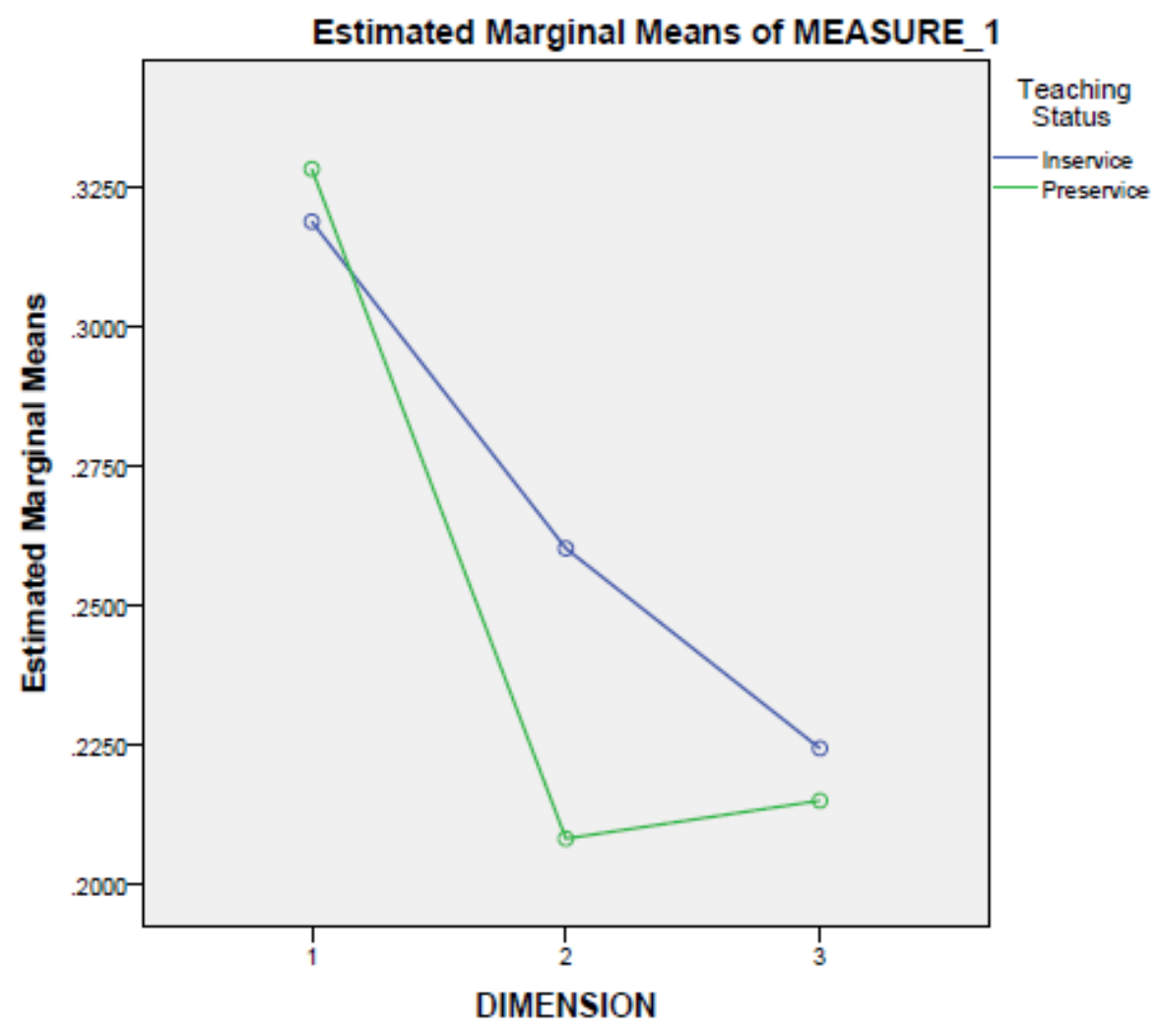

Figure 3. Teaching Status means and Dimension weights.

Gender. Participants included both women $(n=30)$ and men $(n=10)$. Results also revealed the dimension main effect was highly significant $(\Lambda=.16, F[2,37]=95.72, p=.000$, $\left.\eta_{\mathrm{p}}^{2}=.84\right)$; the main effect of gender was non-significant $\left(F[1,38]=0.27, p=.605, \eta_{\mathrm{p}}^{2}=.007\right)$; and the dimension by gender interaction, the effect of interest, was non-significant, $\Lambda=.92, F(2$, $37)=1.65, p=.206, \eta_{\mathrm{p}}^{2}=.08$.

Race/ethnicity. Participants were categorized into "White" $(n=30)$ or "People of Color" $(n=10)$ based on their responses to race and ethnicity questions. Results revealed that the 
dimension main effect was highly significant $\left(\Lambda=.19, F[2,37]=81.46, p=.000, \eta_{p}^{2}=.82\right)$; the main effect of People of Color (POC) was non-significant $\left(F[1,38]=0.88, p=.353, \eta_{\mathrm{p}}^{2}=.02\right)$; and the dimension by POC status, the effect of interest, was non-significant, $\Lambda=.98, F(2,37)=$ $0.29, p=.750, \eta_{\mathrm{p}}^{2}=.015$.

Follow up analysis included adding the three subscales (Perceived Inequality, Egalitarianism, Sociopolitical Action) from the Critical Consciousness Scale as covariates. Results revealed that the dimension main effect was non-significant $(\Lambda=.947, F[2,34]=0.96, p$ $\left.=.395, \eta_{\mathrm{p}}^{2}=.05\right)$; the main effect of Inequality was non-significant $\left(F[1,35]=.65, p=.426, \eta_{\mathrm{p}}^{2}=\right.$ .018); and the Dimension by Inequality interaction, the effect of interest, was non-significant, $\Lambda=.976, F(2,34)=.41, p=.666, \eta_{\mathrm{p}}^{2}=.02$. The main effect of Egalitarianism was nonsignificant $\left(F[1,35]=.01, p=.907, \eta_{\mathrm{p}}^{2}=.00\right)$; and the Dimension by Egalitarianism interaction, the effect of interest, was non-significant, $\Lambda=.999, F(2,34)=.01, p=.988, \eta_{p}^{2}=.001$. The main effect of Sociopolitical Action was non-significant $\left(F[1,35]=2.01, p=.156, \eta_{\mathrm{p}}^{2}=.06\right)$; and the Dimension by Sociopolitical Action interaction, the effect of interest, was non-significant, $\Lambda=.960, F(2,34)=.71, p=.497, \eta_{\mathrm{p}}^{2}=.040$.

Language fluency. Participants were categorized into either being fluent in one $(n=30)$ or two $(n=10)$ languages. Results revealed that the dimension main effect was highly significant, $\left(\Lambda=.183, F[2,37]=82.76, p=.000, \eta_{p}^{2}=.82\right)$; the main effect of Language Fluency was non-significant $\left(F[1,38]=.24, p=.628, \eta_{\mathrm{p}}^{2}=.006\right)$; and the Dimension by Language Fluency interaction, the effect of interest, was non-significant, $\Lambda=.989, F(2,37)=.20, p=.820$, $\eta_{\mathrm{p}}^{2}=.01$ 
Frequency of contact with English learners. Participants' responses were coded into different levels (Never, Less than once a month, Once a week, Several times a week, and Every day) of contact frequency they have with English Learners. Results indicated that the dimension main effect was highly significant, $\left(\Lambda=.298, F[2,34]=40.13, p=.000, \eta_{\mathrm{p}}^{2}=.70\right)$; the main effect of EL Frequency Contact was non-significant $\left(F[4,35]=2.16, p=.095, \eta^{2}=.20\right)$; and the Dimension by EL Frequency Contact interaction, the effect of interest, was marginally significant, $\Lambda=.648, F(8,68)=2.06, p=.052, \eta_{\mathrm{p}}^{2}=.20$. Thus, teacher's frequency of contact with English Learners may have subtle influences on dimension weights (i.e., the salience of the different perceptual dimensions of English Learners), marginally significant results, however, are to be interpreted with caution, especially given the small samples under each level.

Additional multivariate analyses where conducted with frequency of contact recoded as Never $(n=0)$, Some $(n=15)$, or Every Day $(n=20)$ to address the concerns with sample sizes. Results revealed that the dimension main effect was highly significant, $(\Lambda=.199, F[2,36]=$ $72.46, p=.000, \eta_{\mathrm{p}}^{2}=.80$ ); the main effect of EL Frequency Contact was marginally significant $\left(F[2,37]=2.65, p=.084, \eta_{\mathrm{p}}^{2}=.13\right)$; and the Dimension by EL Frequency Contact interaction, the effect of interest, was significant, $\Lambda=.699, F(4,72)=3.54, p=.011, \eta_{\mathrm{p}}^{2}=.16$. This finding indicated that dimension weights are stronger when there is more contact with English Learners (see Figure 4). 


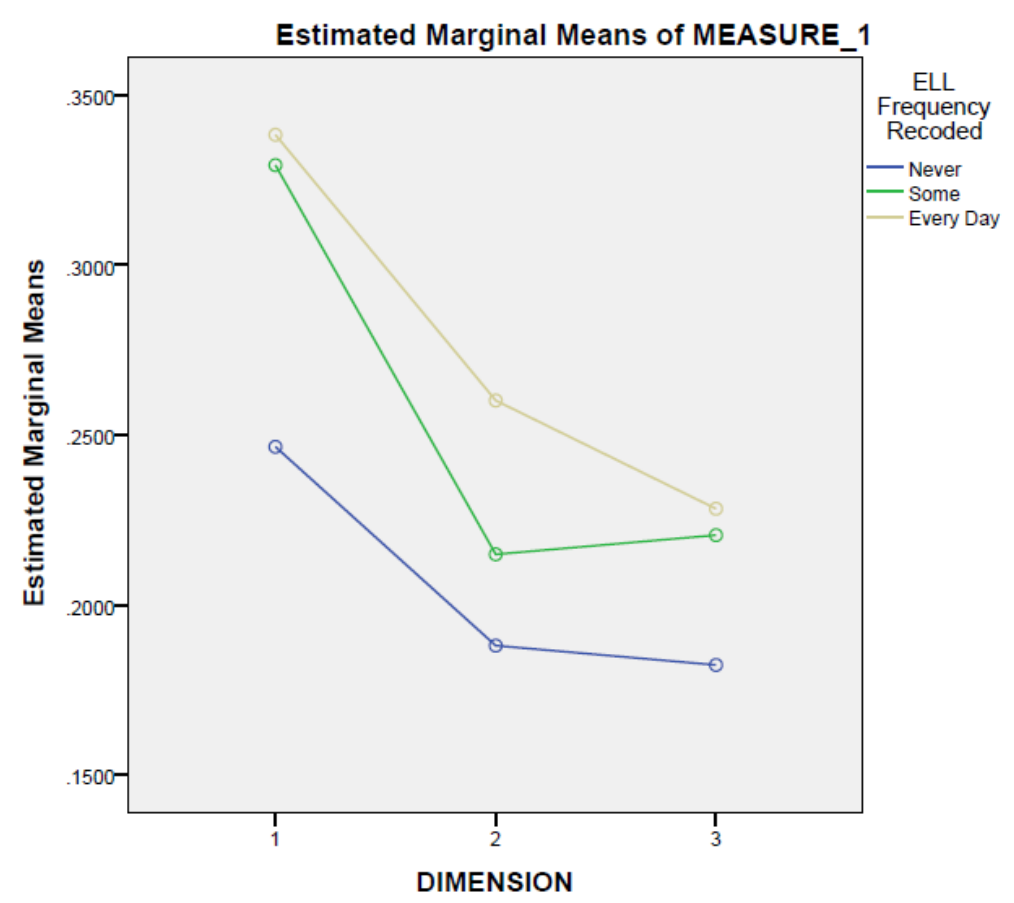

Figure 4. ELL Frequency Contact (re-coded) means and Dimension weights.

Education factors. Previous research studies also indicated various factors that were related to education, such as teachers' obtained level of education, teaching level, number of undergraduate courses taken that focused on ELs, and professional development about working with ELs.

Participant's level of education included holding an Associates $(n=5)$, Some College ( $n$ $=15)$, Bachelors $(n=13)$, and Masters Degree $(n=7)$. Results revealed that the dimension main effect was highly significant $\left(\Lambda=.170, F[2,35]=85.70, p=.000, \eta^{2}=.83\right)$; the main effect of Education Level was non-significant $\left(F[3,36]=1.13, p=.349, \eta^{2}=.09\right)$; and the Dimension by Education Level interaction, the effect of interest, was non-significant, $\Lambda=.785, F(6,70)=1.51$, $p=.189, \eta_{\mathrm{p}}^{2}=.11$. Therefore, participants Education Level does not influence dimension weights.

Participants also provided information on the various types of training they had (i.e., Education Training), ranging from Bilingual Education, Early Education, Secondary Education, 
Special Education, English as a Second Language (ESL), or a combination of two of the above (see Table 13). Multivariate results revealed that the dimension main effect was highly significant $\left(\Lambda=.172, F[2,31]=74.51, p=.000, \eta_{\mathrm{p}}^{2}=.83\right)$; the main effect of Education Training was significant $\left(F[7,32]=2.59, p=.031, \eta_{\mathrm{p}}^{2}=.36\right)$; and the Dimension by Education Training interaction, the effect of interest, was non-significant, $\Lambda=.591, F(14,62)=1.33, p=.215, \eta_{\mathrm{p}}^{2}=$ .23 .

Table 13

Descriptives on Participants Education Training

\begin{tabular}{lccc}
\hline Education Trainings & $n$ & $M(S D)$ & $95 \% \mathrm{CI}$ \\
\hline Bilingual Education & 4 & $.257(.028)$ & {$[.199, .314]$} \\
Early \& Bilingual Education & 1 & $.366(.056)$ & {$[.251, .481]$} \\
Early \& Secondary Education & 5 & $.252(.025)$ & {$[.200, .303]$} \\
Early Education & 13 & $.277(.016)$ & {$[.245, .309]$} \\
Secondary Education & 14 & $.233(.015)$ & {$[.203, .264]$} \\
Special Education & 1 & $.412(.056)$ & {$[.297, .527]$} \\
Special Education (with ESL) & 1 & $.164(.056)$ & {$[.049, .279]$} \\
Special Education (with Learning \& Behavior) & 1 & $.262(.056)$ & {$[.147, .377]$} \\
\hline
\end{tabular}

Another factor that was analyzed was the number of Undergraduate courses focused on teaching English Learners that participants had taken during their training. Nine participants reported having taken 0 courses; 19 participants reported having taken 1 course; 2 participants reported having taken 2 courses; 3 participants reported having taken 2; 4 participants reported having taken 2 courses; and 6 participants reported having taken more than 4 courses. Results revealed that the dimension main effect was highly significant $(\Lambda=.284, F[2,33]=41.65, p=$ $\left..000, \eta_{\mathrm{p}}^{2}=.72\right)$; the main effect of EL Undergraduate Courses was non-significant $(F[5,34]$ $=.589, p=.708, \eta_{\mathrm{p}}^{2}=.08$ ); and the Dimension by EL Undergraduate Courses interaction, the effect of interest, was non-significant, $\Lambda=.784, F(10,66)=.853, p=.581, \eta^{2}{ }_{p}=.11$. 
Finally, participants indicated Yes $(n=21)$ or No $(n=19)$ if they had received professional development related to teaching ELs (see Figure 5). Multivariate results revealed that the dimension main effect was highly significant $\left(\Lambda=.145, F[2,37]=108.67, p=.000, \eta_{p}^{2}=\right.$ $.86)$; the main effect of Professional Development was non-significant $(F[1,38]=.064, p=.801$, $\left.\eta_{p}^{2}=.002\right)$; and the Dimension by Professional Development interaction, the effect of interest, was marginally significant, $\Lambda=.860, F(2,37)=3.01, p=.061, \eta_{\mathrm{p}}^{2}=.14$.

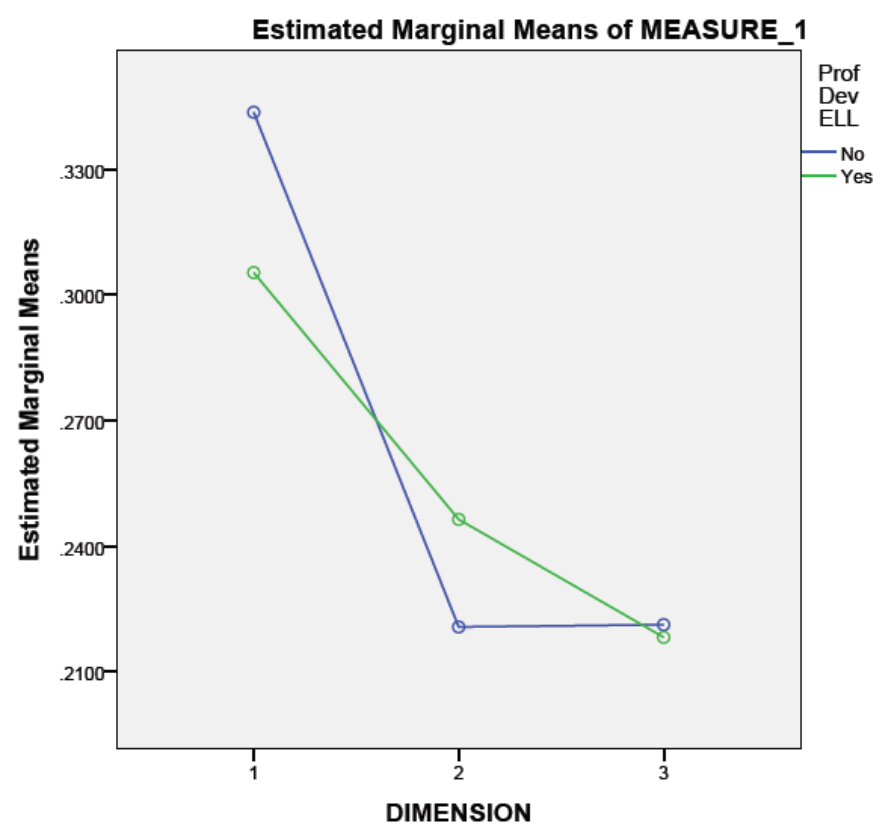

Figure 5. Professional Development means and Dimension weights. 


\section{CHAPTER V: DISCUSSION}

Historically, educational policies and language policies have played a major role in who obtains an education as well as who can access instruction (Koyama, 2004). Language policies have been influenced by the rise of immigrants in the United States, with school populations having an increase of English Learners (ELs) or English Language Learners (Mantero \& McVicker, 2006). The rise of ELs in schools led to various federal and civil rights cases, such as the Chicano civil rights movements or East L.A. "walkouts" in 1968, Lau v. Nichols (1974), Serna v. Portales Municipal Schools (1974), Rios v. Read (1978), and U.S. v. Texas (1981), Plyver v. Doe (1982), Castaneda v. Pickard (1981), that produced policies to assure ELs had access to instruction, equal educational opportunities, and supports through language programs.

Despite federal policies that influenced the development of bilingual and language programs in schools, there are also sentiments of "English-only" from state policies in California, Arizona, and Colorado (Mantero \& McVicker, 2006; Shin et al., 2015). These contradicting policies have been influenced by the socio-political attitudes specifically towards Latinx immigrants or Spanish-speaking immigrants threatening "American" patriotism values (Shin et al., 2015). These larger macrosystem attitudes impact smaller microsystems, such as schools and teachers' beliefs, perceptions and practices (Bandura, 1986; Bronfenbrenner, 1979; Fang, 1996; Mantero \& McVicker, 2006).

The U.S. Department of Education reported in The Condition of Education (2019) an estimate of more than four million English Learners in public schools, with $76 \%$ of them being Spanish-speaking students (NCELA, 2017; NEA, 2017). Student demographics have become more culturally and linguistically diverse while the teaching staff has remained homogenously White and female, leading to a cultural mismatch between students and teachers (Moreno \& 
Gaytan, 2013). Consequently, these mismatches lead to teacher-based prejudices, biases, microaggressions, discrimination, stereotypes, misconceptions, and deficit-oriented perceptions (Benner \& Graham, 2011; Ford et al., 2013; Gonzalez \& Ayala-Alcantar, 2008; Moreno \& Gaytan, 2013; Staats, 2016). These deficit misconceptions of English Learners have been found to impact teachers' practices where ELs are vulnerable to an instruction from a pedagogy of poverty (Diaz et al., 2013). Research studies have supported that teacher's perceptions impact student's achievement and academic performance (Diaz et al., 2013; Ferguson, 1998, as cited in Callahan; Ghaouar, 2015; Glock \& Karbach, 2015; Glock \& Kovacs, 2013; Lumdsen, 1997; Mantero \& McVicker, 2006; Richardson, 1996; Sas, 2009; van der Bergh et al., 2010, as cited Glock \& Kovacs, 2013; Youngs \& Youngs, 2001). However, these perceptions have been impacted by various factors such as demographic characteristics, contact with ELs, teaching experience, undergraduate courses about ELs, and professional development (Marx, 2002/2009; Matero \& McVicker, 2006; Pettit, 2011; Sas, 2009; Youngs \& Youngs, 2001).

These misperceptions, myths, and deficit perceptions of students have been found to be challenged or deconstructed by exposing teachers to counter-narratives, training, cultural immersion, guided reflections, and courses rooted in a critical race theory (Fránquiz et al., 2011; Gonzalez \& Ayala-Alcantar, 2008; Kolano \& King, 2015; Markos, 2012; Ortiz, 2011). These perceptions are usually changed through developing a critical pedagogy or critical caring praxis. Therefore, another factor that was taken into consideration as a potential influence were teachers' level of critical consciousness.

Considering the strong implications that teachers' perceptions have upon students' academic performance, the current study considered it critical to continue examining teachers' perceptions of English Learners. A literature review was completed to obtain a comprehensive 
understanding of teachers' perceptions toward English Learners, which helped with development of the stimuli. The literature review also reflected that the current studies have used qualitative or quantitative methodological approaches that posed limitations towards examining implicit perceptions. The purposes of the current study were to 1) discover pre-service and in-service teachers underlying perceptual dimensions of English Learners, 2) identify the factors that influence these perceptual dimensions, and 3) assess the influence that a Critical Consciousness has on perceptions of English Learners.

To address these purposes, the current study had pre-service and in-service teachers complete a card-sorting task of statements of English Learners. These statements were derived from the existing literature that was initially comprised of approximately 400 individual statements. These statements were then categorized into 28 categories, resulting in 92 statements for the card-sorting task. Participants also completed a 7-point Likert scale to indicate the level of truthfulness for each statement. Data from the card-sorting task was analyzed using Nonmetric Multidimensional Scaling (NMDS) techniques, to discover cognitive maps or configurations of a visual representation of the dimensions or perceptions held by teachers toward English Learners. Individual differences by participants and subgroup differences were analyzed by using the questionnaire data (e.g., demographics, truthfulness ratings, and critical consciousness). Results of the current study expand our understanding of teachers' perceptions toward English Learners through the use of Multidimensional Scaling (MDS) as well as identify factors that influence teacher's perceptions.

\section{Summary of Findings}

The current study was the first one known to use MDS to generate cognitive maps of teachers' perceptions toward English Learners. It was also the first study to complete a 
comprehensive literature analysis of teachers' perceptions to develop stimuli for a card-sorting task. A critical component of this study required the research to examine and interpret the dimensions generated from using Multidimensional Scaling (MDS) and Individual Differences Scaling (INDSCAL) analyses.

\section{MDSCAL Results}

Results from MDSCAL solution generated three dimensional configurations, which suggested that all participants attended primarily to a statement being Positive vs. Negative during the card-sorting task. Their perceptions were secondarily influenced by whether a statement was about English Learners or about Teachers, thus comprising the Dimension 2: Student Statements vs. Teacher Statements. Finally, perceptions were also influenced by the systemic barriers or resources teachers' encounter when teaching English Learners; thus Dimension 3 represents Systemic Barriers vs. Resources.

\section{INDSCAL Results}

As discussed, INDSCAL was used to examine individual differences across participantby-participant and subgroup (pre-service vs. in-service teachers) differences. These individual differences were examined by analyzing subject weights. Results from INDSCAL participantby-participant did not generate an optimal solution, mirroring similar conclusions made by Pecho (2017) where the binary nature of the sorting data at an individual level resulted in similar findings.

INDSCAL analysis by teaching status (Pre-service vs. In-service teachers) subgroups generated a solution with 3 dimensions. Examination of these dimensions, as well as correlations with MDSCAL dimensions, indicated that both MDSCAL and INDSCAL generated highly similar perceptual dimensions. 
Subject weights of participants teaching status (Pre-service vs. In-service) were compared to measure the importance of each dimension to each subgroup. Subject weights indicated that both Pre-service and In-service attended roughly the same amount and primarily to Dimension 1 (whether statements were Positive or Negative). The second-most important dimension for both Pre-service and In-service teachers was Dimension 2: Student Statements vs. Teacher Statements. Dimension 2 has similar subject weights across both subgroups suggesting that both Pre-service and In-service teachers attend about the same to whether statements are about students (English Learners) or about teachers. Finally, a differentiation between subgroups weights occurred in Dimension 3, which indicated that In-service teachers attend about two times more to this dimension in comparison to Pre-service teachers. I concluded that teaching status, which includes the amount of teaching experience, appears to impact the ability of participants to attend to these systematic barriers and resources encountered when teaching English Learners. Based on this finding, I concluded that teaching experience matters, which is a factor that has been found to influence teachers' perceptions of English Learners (Mantero \& McVicker, 2006). This factor of teaching experience was also further analyzed and findings are discussed below.

\section{Correlations with Other Factors}

Participants completed two rating scales: (1) Truthfulness Likert scale and (2) Critical Consciousness Scale. Correlations were conducted to examine the relations between the average Truthfulness rating from Pre-service teachers, In-service teachers, and all participants with each dimension identified in MDSCAL and INDSCAL analyses. Findings suggested that Dimension 1 had the same interpretation across individual differences analysis by subgroups (INDSCAL) and MDSCAL, which led to similar patterns of correlation results (see Table 8) for Dimension 1 
from INDSCAL by subgroup. The average Truthfulness ratings for pre-service, in-service, and all teachers were positively correlated with this Dimension 1.

Correlations were conducted between participants' Critical Consciousness and their perceptions of English Learners as indicated by results from Dimensions 1, 2, and 3. Results indicated no significant correlations between the three different Critical Consciousness subscales and Dimensions 1, 2, or 3. Therefore, teachers' critical consciousness does not relate to their perceptions of English Learners.

\section{Repeated Measures MANOVAS}

Analysis were conducted to examine the impact various demographic factors as indicated by previous research studies had upon teachers' perceptions toward English Learners (Mantero \& McVicker, 2006; Marx, 2002/2009; Sas, 2009; Youngs \& Youngs, 2001). Statistical analysis included conducting Repeated Measure MANOVAS to examine the influence these factors had upon Dimension 1, 2, and 3. Results indicated significant interaction findings for the following factors: Teaching Status (Pre-service vs. In-service), Frequency of Contact with ELs, and Professional Development. Therefore results suggest that the frequency of contact is a factor that strongly influences teachers' perceptions of English Learners. Professional Development also had a subtle influence on Dimension weights, such that the less Professional Development the more teachers attended to Dimension 1 and less to Dimension 2 and 3 (see Figure 5). Also, the more Professional Development, the less teachers attended to Dimension 1; and there was more variability to attending Dimension 2 and 3. Results indicated non-significant interaction findings for the following factors: Gender, Race/Ethnicity, Language Fluency (i.e., being monolingual or bilingual), Education level (i.e., participants level of education), Education Training (e.g., 
Bilingual, Early, Secondary, etc.), Undergraduate courses focused on ELs. Therefore, these factors did not have any influence on the dimension weights.

\section{Summary and Implications}

In summary, the results of the current study expand on the current understanding of teachers' perceptions toward English Learners. Similar to Pecho (2017), which used a similar methodological approach, the current study indicated that MDS was an appropriate methodological approach to examine teachers' perceptions toward English Learners. Results generated a visual representation through a cognitive map of teachers' perceptions toward English Learners. This cognitive map encompassed a three dimensional solution. Dimension 1 was interpreted to represent the valence (Positive vs. Negative) of each stimuli item; Dimension 2 was interpreted to represent statements about English Learners or Teachers in the stimuli; and Dimension 3 was interpreted to represent the Systemic Barriers and Resources encounter when teaching ELs. Findings per subject weights comparisons also indicated that both Pre-service and In-service teachers' perceptions were primarily influenced by Dimension 1, then Dimension 2, and lastly Dimension 3. Within Dimension 3, In-service teachers' perceptions were two times as important to their classification in comparison to Pre-service teachers, suggesting teaching experience matters when attending to Systemic Barriers or Resources. Additionally, teachers' perceptions were found to be influenced by their Teaching Status (Pre-service vs. In-service), Frequency of Contact with ELs, and Professional Development. Other demographic factors, such as gender, race/ethnicity, and language fluency did not have any influence on dimension weights. This finding suggests that teachers' demographics or background might not have a big of an impact upon their perceptions toward English Learners. 
The current study has several educational and clinical implications. Based on the MDS findings from this current study, teachers (Pre-service and In-service) were able to identify and differentiate statements from positive vs. negative statements about English Learners. This finding can be related to being able to differentiate between deficit-based and asset-based statements of English Learners. Previous studies have emphasized the importance of deconstructing deficit-based perceptions by being exposed to counter-narratives, which are essentially asset-based narratives of English Learners (Fránquiz et al., 2011; Gonzalez \& AyalaAlcantar, 2008; Kolano \& King, 2015; Markos, 2012; Ortiz, 2011). Another critical factor that helps with deconstructing deficit-based perceptions involves cultural immersions experiences. These immersion experiences are often encountered when educators begin to teach, which is when they experience direct contact with EL students as well as professional development about working with ELs. Therefore, it can be concluded that teaching experience matters and it may be a critical time period for teachers to be able to deconstruct their deficit-based perceptions of English Learners.

Another educational implication based on the Dimensions that were identified is that teachers' thinking is generally on a continuous distribution that ranges between two opposing ends. For example, teachers were able to sort out stimuli from positive vs. negative, about ELs vs. about teachers, or Systemic Barriers vs. Resources, as seen across all dimensions. Their thinking did not reflect the ability to identify various content areas (e.g., 28 categories as identified by researcher) in the card-sorting piles data. The majority of participants sorted the cards into two to three piles, reflecting a categorical thinking.

Clinical implications, specifically for school psychologists, involve being familiar with the factors that impact and can influence teachers' perceptions. As school psychologist we are 
often consulting with teachers and working in collaboration when evaluating student's academic and social/emotional performance. With our student population becoming more culturally and linguistically diverse, it is critical to also have an understanding of how teachers' perceptions can impact English Learners' performance. School psychologists can also influence systems and advocate for teacher's to obtain professional development about working with ELs.

\section{Limitations and Future Directions}

Although, the current study contributed important findings that have expanded the understanding of teachers' perceptions toward English Learners, there were various limitations. Current findings should not be over-generalized considering the limitations encounter with the obtained sample. The study consisted of majority white-female participants $(n=30)$, possibly impacting findings when examining gender and race/ethnicity and their influences on dimension weights. Participants' lack of diverse backgrounds may also have contributed to the lack of significant findings between participants' critical consciousness, as measured with the CCS, and dimension weights. The obtained sample, however, can be considered representative of the current teaching population. Another limitation is that participants were drawn from a convenience sample of an undergraduate institution and school district in Illinois. Teachers' perceptions toward English Learners may differ from our current findings among a sample of participants in other regions of the country, which may be more racially/ethnically and linguistically diverse. Therefore, future studies should replicate the current study with a sample of participants that is more diverse in gender, race/ethnicity and linguistically.

Another limitation was found when analyzing individual differences by participants due to the card-sorting data being binary in nature. This limitation was also observed in Pecho (2017), where it was suggested for future studies to consider different data collection methods to 
prevent binary data. This may involve exploring different methodology besides card-sorting tasks. However, this methodology may be considered for future studies when examining subgroup differences, such Pre-service vs. In-service teachers. Further, the Pre-service and Inservice teachers' differences in subject weights may also reflect differences due to age. Thus, future research should consider controlling for age.

Although, MDS has a lot of methodological strengths, such as discovering underlying dimensions. Similar to Pecho (2017) the current researcher also noted that these dimensions were influenced by the researcher's subjective interpretation when analyzing the ends of each dimension. For example, Dimension 3 was less straightforward when interpreting and could potentially be interpreted as something else depending on the researchers' perspective. Future studies could follow up with participants after running MDS analyses to help with interpreting the dimensions.

Although, the current study examined teachers' perceptions by using teachers as participants, future studies may also consider examining teachers' perceptions of English Learners by having students complete the card-sorting task to examine differences. This was noted in a study by Garcia and Chun (2016), where the sample was comprised of Latino students to investigate the effects of culturally responsive teaching and teacher expectations. Another population that future studies may also consider is school psychologist perceptions towards English Learners, especially due to the critical role they play in completing evaluations, consultation, and system-changes in schools.

In summary, teachers' perceptions toward English Learners are of similar constructs across Pre-service and In-service teachers. While a teachers' critical consciousness does not appear to influence their perceptions, factors such as Teaching Status, Frequency of Contact with 
ELs, and Professional Development do indicate to influence these perceptual dimensions. Based on these data, it can be concluded that teaching experience matters. In particular the more years in teaching experience, training and interaction with ELs was seen to influence perceptions to be more complex. In-service teachers demonstrate more nuance and more complex perceptions of English Learners than the Pre-service counterparts, a difference that would be important to follow up in future research. 


\section{REFERENCES}

Abu-Rabia, S. (2004) Teachers' role, learners' gender differences, and FL anxiety among seventh-grade students studying English as a FL. Educational Psychology, 25, 711-721. doi: 10.1080/0144341042000263006

Artiles, A. J., Rueda, R., Salazar, J. J., \& Higareda, I. (2005). Within-group diversity in minority disproportionate representation: English language learners in urban school districts. Exceptional Children, 71, 283-300.

Bandura, A. (1986). Social foundations of thought and action: A social cognitive theory. Englewood Cliffs, NJ: Prentice-Hall.

Becerra, D. (2012). Perceptions of educational barriers affecting the academic achievement of Latino K-12 students. Children and Schools, 34, 167-177.

Benner, A. D., \& Graham, S. (2011). Latino adolescents' experiences of discrimination across the first two years of high school: Correlates and influences on educational outcomes. Child Development, 82(2), 508-519.

Bianco, M., \& Harris, B. (2014). Strength-based RtI: Developing gifted Spanish-speaking English language learners. Gifted Child Today, 37, 169-176.

Borna, T. A. (2015). Analyzing teachers' role in converting unsuccessful self-image of a learner into a successful one. ASA University Review, 9, 301-315.

Bronfenbrenner, U. (1979). The ecology of human development. Cambridge, MA: Harvard University Press.

Byrnes, D.A., Kiger, G., \& Manning, M.L. (1997). Teachers' attitudes about language Diversity. Teacher and Teacher Education, 13, 637-644. 
Callahan, R. M. (2005). Tracking and high school English learners: Limiting opportunity to learn. American Educational Research Journal, 42, 305-328.

Capps, R., M. Fix, J. Murray, J. Ost, J. Passel, \& S. Herwantoro. (2005). The new demography of America's schools: Immigration and the no child left behind act. The Urban Institute, $18,1-41$

Carjuzaa, J. (2007). Cultural plunges: Pre-service teachers confront unacknowledged biases. The International Journal of Diversity in Organizations, Communities and Nations, 7, 153160.

Clark, P., \& Zygmunt, E. (2014). A close encounter with personal bias: Pedagogical implications for teacher education. The Journal of Negro Education, 83, 147-161.

Cummins, J. (2001). Negotiating identities: Education for empowerment in a diverse society $\left(2^{\mathrm{nd}}\right.$ ed.). Ontario, CA: California Association for Bilingual Education.

de Jong, E. J., Harper, C. A., \& Coady, M. R. (2013). Enhanced knowledge and skills for elementary mainstream teachers of English language learners. Theory into Practice, 52, 89-97.

Diaz, Z., Whitacre, M., Esquierdo, J. J., \& Ruiz-Escalante, J. A. (2013). Why did I ask that question? Bilingual/ESL pre-service teachers' insights. International Journal of Instruction, 6, 163-176.

Diemer, M. A., Rapa, L. J., Park, C. J., \& Perry, J. C. (2017). Development and Validation of the Critical Consciousness Scale. Youth and Society, 49(4), 461-483.

Doorn, K., \& Schumm, J. S. (2013). Attitudes of pre-service teachers regarding linguistic diversity in the general education classroom. Journal of Reading Education, 38, 28-37. 
Estrada, V. L., Gómez, L., \& Ruiz-Escalante, J. A. (2009). Let's make dual language the norm. Educational Leadership. 54-58.

Fang, Z. (1996). A review of research on teacher beliefs and practices. Educational Research, $38(1), 47-65$.

Fazio, R. H. (1986). How do attitudes guide behavior? In R. M. Sorrentino, \& E. T. Higgins (Eds.), The handbook of motivation and cognition: foundations of social behavior (pp. 204-243). New York, NY: Guilford.

Fazio, R. H., \& Towles-Schwen, T. (1999). The MODE model of attitude-behavior processes. In S. Chaiken, \& Y. Trope (Eds.), Dual process theories in social psychology (pp. 97116). New York, NY: Guilford.

Ford, D. Y., Scott, M. T., Moore, J. L., \& Amos, S. O. (2013). Gifted education and culturally different student students: Examining prejudice and discrimination via microaggressions. Gifted Child Today, 36, 205-208.

Fránquiz, M. E., Salazar, M. C., \& DeNicolo, C. P. (2011). Challenging majoritarian tales: Portraits of bilingual teachers deconstructing deficit views of bilingual learners. Bilingual Research Journal, 34, 279-300.

Garcia, C., \& Chun, H. (2016). Culturally responsive teaching and teacher expectations for Latino middle school students. Journal of Latina/o Psychology, 4, 173-187.

Ghaouar, N. (2015). Teachers' beliefs and practice in the linguistics classroom. Journal of History Culture and Art Research, 4, 78-90.

Giguère, G. (2006). Collecting and analyzing data in multidimensional scaling experiments: A guide for psychologists using SPSS. Tutorials in Quantitative Methods for Psychology, 2(1), 26-38. 
Glock, S., \& Karbach, J. (2015). Preservice teachers' implicit attitudes toward racial minority students: Evidence from three implicit measures. Studies in Educational Evaluation, 45, $55-61$.

Glock, S. S., \& Kovacs, C. (2013). Educational psychology: Using insights from implicit attitude measures. Educational Psychology Review, 25, 503-522.

Gonzalez, R., \& Ayala-Alcantar, C. U. (2008). Critical caring: Dispelling Latino stereotypes among preservice teachers. Journal of Latinos and Education, 7, 129-143

Green, R. J., \& Manzi, Jr., R. (2002). A comparison of methodologies for uncovering the structure of racial stereotype subgrouping. Social Behavior and Personality: An International Journal, 30(7), 709-727. doi:10.2224/sbp.2002.30.7.709

Griego, T. (2002). Preparing all teachers for linguistic diversity in K-12 schools. Paper presented at the annual meeting of the American Association of Colleges for Teacher Education, New York, NY.

Harper, C. \& de Jong, E. (2004). Misconceptions about teaching English-language learners. Journal of Adolescent and Adult Literacy, 48, 152-162.

Jaworska, N., \& Chupetlovska-Anastasova, A. (2009). A review of multidimensional scaling (MDS) and its utility in various psychological domains. Tutorials in Quantitative Methods for Psychology, 5, 1-10

Jiménez, A. (n.d.). From bilingualism to interlinguistics: The case against the deficit model of language acquisition.

Kahnman, D. (2011). Thinking, fast, and slow. New York, NY: Farrar, Straus and Girous.

Kayi-Adar, H. (2015). Teacher agency, positioning, and English language learners: Voices of pre-service classroom teachers. Teaching and Teacher Education, 45, 94-103. 
Kolano, L. Q. \& King, E. T. (2015). Preservice teachers' perceived beliefs towards English language learners: Can a single course change attitudes? Issues in Teacher Education, 24, $3-31$.

Koyama, J. P. (2004). Appropriating policy: Constructing positions for English Language Learners. Bilingual Research Journal, 28(3), 401-423.

Kruskal, J. B., \& Wish, M. (1978). Multidimensional scaling. Beverly Hills, CA: Sage.

Lucas, D., \& Frazier, B. (2014). The effects of a service-learning introductory diversity course on preservice teachers' attitudes toward teaching diverse student populations. Academy of Educational Leadership Journal, 18, 91-124.

Lucas, T., Villegas, A. M., \& Freedson-Gonzalez, M. (2008). Linguistically responsive teacher education: Preparing classroom teachers to teach English language learners. Journal of Teacher Education, 59, 361-373.

Lumsden, L. (1997). Expectations for students. Eugene, OR: National Clearinghouse on Educational Management. (ERIC Reproduction Service No. ED333622).

Mantero, M., \& McVicker, P. (2006). The impact of experience and coursework: Perceptions of second language learners in the mainstream classroom. Radical Pedagogy, 8, 1-17.

Markos, A. M. (2012). Mandated to learn, guided to reflect: Pre-service teachers' evolving understanding of English language learners. Issues in Teacher Education, 21, 39-57.

Marx, S. (2000). An exploration of pre-service teacher perceptions of second language learners in the mainstream classroom. Texas Papers in Foreign Language Education, 5, 207-221.

Miller, P. C., \& Mikulec, E. A. (2014). Pre-service teachers confronting issues of diversity though a radical field experience. Multicultural Education, 18-24. 
Moreno, G. \& Gaytan, F. X. (2013). Focus on Latino learners: Developing a foundational understanding of Latino cultures to cultivate student success. Preventing School Failure, 57, 7-16.

National Education Association (NAE). (2008). English language learners face unique challenges. NEA Education Policy and Practice Department. Retrieved March 7, 2016, from http://www.nea.org/assets/docs/HE/ELL_Policy_Brief_Fall_08_(2).pdf

Olson, M. A., \& Fazio, R. H. (2009). Implicit and explicit measures of attitudes: The perspective of the MODE model. In R. E. Petty, R. H. Fazio, \& P. Briñol (Eds.), Attitudes: Insights from the new implicit measures (pp. 19-63). New York, NY: Psychology.

Ortiz, C. (2011). Don't believe the hype: Challenging deficit perspectives from the inside. In J. G. Irizarry (Ed.), The Latinization of U.S. schools: Successful teaching and learning in shifting cultural contexts (pp. 39-56). New York, NY: Paradigm Publishers

Pappamihiel, E. (2007). Helping preservice content-area teachers relate to English language learners: An investigation of attitudes and beliefs. TESL Canada Journal, 24(2), 42-60.

Pecho, K. (2017). Cognitive maps of attitudes toward unauthorized immigrants: A multidimensional scaling perspective (Doctoral dissertation). Illinois State University, Normal, IL.

Penfield, J. (1987). ESL: The regular classroom teacher's perspective. TESOL Quarterly, 21(1), 21-39.

Pettit, S. K. (2011). Teachers' beliefs about English language learners in the mainstream classroom: A review of the literature. International Multilingual Research Journal, 5, 123-147. doi: 10.1080/19313152.2011.594357 
Richardson, V. (1996). The role of attitudes and beliefs in learning to teach. In J. Sikula (Ed.). Handbook of research on teacher education (2 ${ }^{\text {nd }}$ ed., pp. 102-119). New York, NY: Macmillan.

Rodgers, J. L. (1991). Matrix and stimulus sample sizes in the weighted MDS model: Empirical metric recovery functions. Applied Psychological Measurement, 15(1), 71-77.

Rosenberg, S., \& Kim, M. P. (1975). The method of sorting as a data-gathering procedure in multivariate research. Multivariate Behavioral Research, 10(4), 489.

The National Clearinghouse for English Language Acquisition and Language Instruction Educational Programs (NCELA), 2007, www.ncela.gwu.edu/expert/fastfaq/4.html Salerno, A. S., \& Kibler, A. K. (2013). Before they teach: How pre-service teachers plan for linguistically diverse students. Teacher Education Quarterly, 40(4), 5-26.

Sas, M. M. (2009). Teacher candidates' attitudes toward immigration and teaching learners of English as a second language (Doctoral dissertation). Retrieved from University of Nevada, Las Vegas (UNVL) Theses, Dissertations, Professional Papers, and Capstones, Paper 140.

Shin, H., Leal, D. L., \& Ellison, C. G. (2015). Does anti-Hispanic bias motivate opposition to non-English languages? Sociological Inquiry, 85, 375-406.

Staats, C. (2016). Understanding implicit bias: What educators should know. American Educator, 29-38.

U.S. Department of Education (2019). English Language Learners in Public Schools. The Condition of Education, 1-4. Retrieved from https://nces.ed.gov/programs/coe/indicator_cgf.asp 
Walker, A., Shafer, J., \& Iiams, M. (2004). "Not in my classroom": Teacher attitudes towards English language learners in the mainstream classroom. NABE Journal of Research and Practice, 2, 130-160.

Whaley, A. L., \& Longoria, R. A. (2009). Preparing card sort data for multidimensional scaling analysis in social psychological research: A methodological approach. Journal of Social Psychology, 149(1), 105-115.

Wolfram, W. (2013). Challenging language prejudice in the classroom. Teaching Tolerance, 43, 29-31.

Wong, C., Indiatsi, J., \& Wong, G. W. (2016). ESL teacher candidates’ perceptions of strengths and inadequacies of instructing culturally and linguistically diverse students: post clinical experience. Journal of Cultural Diversity, 23, 57-64.

Youngs, C. S., \& Youngs, G. A. (2001). Predictors of mainstream teachers' attitudes towards ESL students. TESOL Quarterly, 35, 97-120. 


\section{Demographics and Background}

ID \#:

Age:

Race:

Gender: Ethnicity:

What is the highest grade of school you have completed, or the highest degree you have received?

$\square$ Elementary and Junior high school (grades 1-8)

$\square$ High school (grades 9-12, no degree)

$\square$ High school graduate (or equivalent)

$\square$ Some college (1-4 years, no degree)

$\square$ Associate's degree (including occupational or academic degrees)

$\square$ Bachelor's degree (BA, BS, AB, etc)

$\square$ Master's degree (MA, MS, MENG, MSW, etc)

$\square$ Professional school degree (MD, DDC, JD, etc)

$\square$ Doctorate degree (PhD, EdD, etc)

What education program are you currently enrolled in or received your educational training from?

$\square$ Early Education

$\square$ Secondary Education

$\square$ Bilingual Education

How many years do you have in teaching experience?
$\square<1$ year
$\square 2$ years
$\square 3$ years
$\square 4$ years
$\square 5$ years
$\square 6$ years
$\square$ more than 7 years 
How many languages are you fluent in?
$\square 1$
$\square 2$
$\square 3$
$\square$ more than 3

Do you have experience learning a foreign language?

$\square$ Yes

$\square$ No

If you answered yes, how would you describe your experience?

$\square$ Extremely good

$\square$ Good

$\square$ Neutral

$\square \mathrm{Bad}$

$\square$ Extremely bad

How many undergraduate level courses have you taken focused on English Learners?
$\square 1$
$\square 2$
$\square 3$
$\square 4$
$\square$ more than 4

How many graduate level courses have you taken focused on English Learners?
$\square 1$
$\square 2$
$\square 3$
$\square 4$
$\square$ more than 4

Have you had professional development about English Learners?
$\square$ Yes
$\square$ No

If you answered yes, when was the last time you had this training?

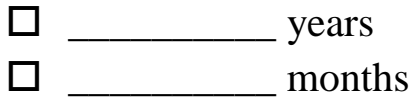


Do you have experience working with English Learners?

$\square$ Yes

$\square$ No

If you answered yes, how would you describe your contact with English Learners?

$\square$ Extremely good

$\square$ Good

$\square$ Neutral

$\square \mathrm{Bad}$

$\square$ Extremely bad

Did you have exposure to English Learners while you were in K-12?

$\square$ Yes

$\square$ No

How often do you have contact (verbal or non-verbal) with students that are English Learners?

$\square$ Never

$\square$ Less than once a month

$\square$ Once a month

$\square$ Several times a month

$\square$ Once a week

$\square$ Several times a week

$\square$ Every day

Approximately, how many English Learner students have you taught over the course of your career? 


\section{APPENDIX B: PRACTICE CARDS}

CARDS FOR PRACTICE CARD-SORTING TASK- to be cut out and laminated into 3x5 index cards

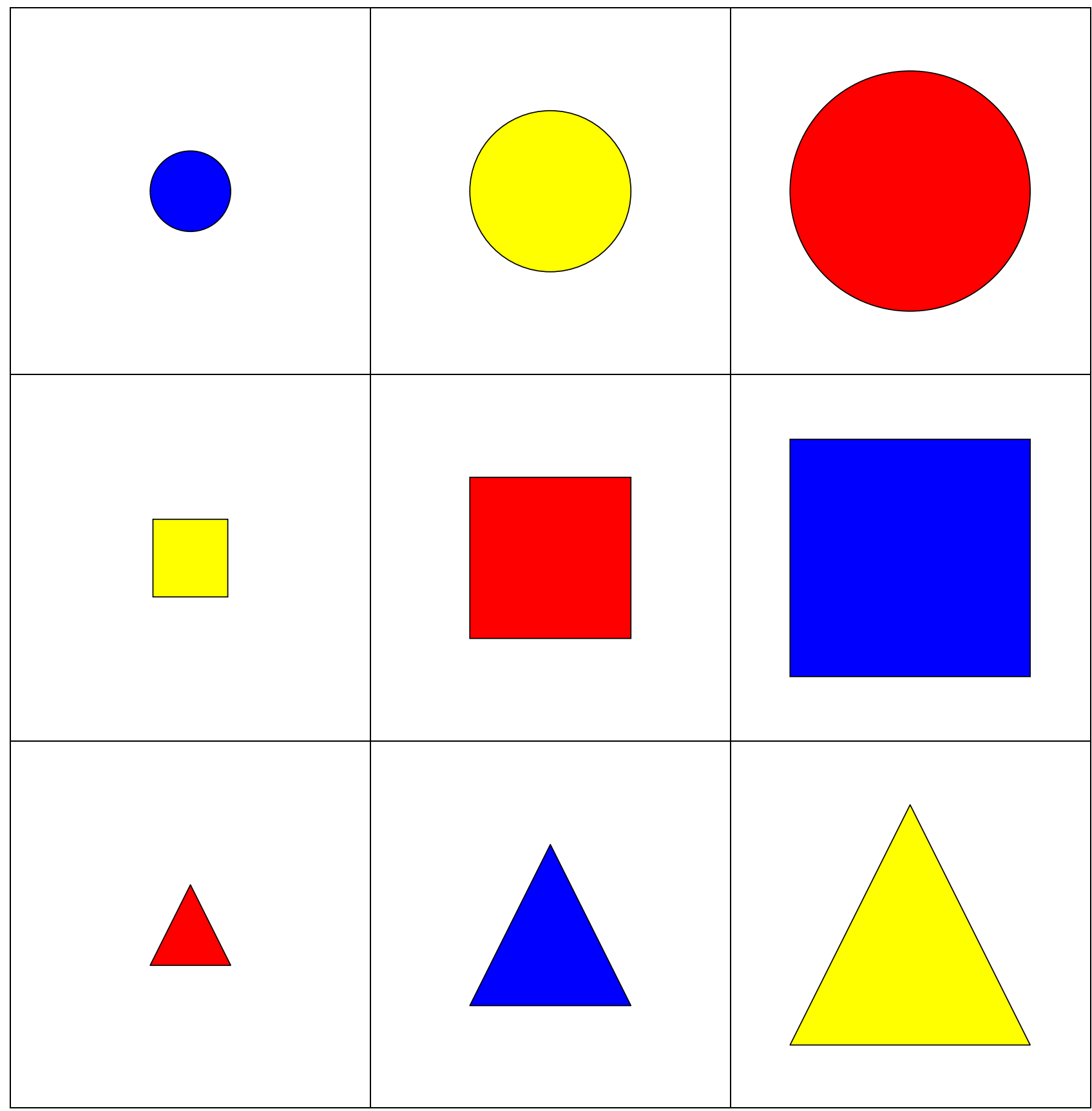

Adapted from Pecho (2017). 


\title{
APPENDIX C: CARD-SORTING TASK INSTRUCTIONS
}

\author{
Instructions \\ (Adapted from Pecho, 2017)
}

"You are participating in a study that is investigating the characteristics among English Learners or students that you may potentially have in your classroom. The following component of the study is a card-sorting task. To make sure you have understood the task, you will first complete a practice trial. I will also use a timer to collect data on duration of the task, however this task is not a timed task and you have as long as you need to complete the task."

"There are nine practice cards in front of you. When I say 'begin', please sort the cards into piles, placing similar cards in the same pile and dissimilar cards in a different pile(s). At least two piles must be created, and there is no right or wrong way of sorting the cards. When you are done please let me know by saying, 'Done"'

"Begin." (Start timer)

(After sorting)

“Thank you. Tell me about how did you decide to sort the cards?"(Response should indicate, by color/size/shape)

"Good. You indicated to understand that cards are to be sorted on similarities and created at least two piles. It was possible to sort them in a different way, such as (name a different way from the indicated above). Both ways of sorting cards are acceptable, there is not a right or wrong way of sorting the cards into piles. Cards are to be sorted based on however you perceive them to similar."

"Now, that you seem to understand how to do the card-sorting task. I am going to ask you to sort more cards. Here is a stack of index-cards that have statements about English Learners. These statements were gathered from the extant literature about English Learners. The statements are not organized in any particular order. Your task is to sort the cards/statements into piles based on similarity. Therefore, statements that you perceive to be similar should be placed into the same pile. Statements that you perceive to not be similar should not be placed in the same pile. You may place as little as one card per pile, but you must create more than two piles. Also, there is not a right or wrong way to sort the cards."

"Remember: It is important to focus on the degree of similarity of each statement, not your level of agreement or disagreement with each statement."

"When I say Begin, you may start sorting the cards into piles, and please indicate when you're done... Begin" (Start Timer).

(Stop timer when participant indicates being Done sorting)

(After sorting) 
"Please bind the cards in each pile with a rubber band to make sure they remain sorted. Now, take a post-it-note and pen and assign a label to each pile. There are not right or wrong labels."

\section{(After labeling)}

"Remember, there are not right or wrong way of sorting or group the cards, and many people do not change their piles. However, after labeling each pile, now you have the opportunity to determine if you are satisfied with your sorting of each statement. If there is a statement(s) that you are not satisfied, this is the time to move it to a different pile."

"Thank you for your participation." 


\section{APPENDIX D: TRUTHFULNESS LIKERT RATING SCALE}

Instructions: Please read the following statements about English Learners that were obtained from the extant literature. On a scale from 1 (completely false) to 7 (completely true), please rate the extent to which each of the following statements is true.

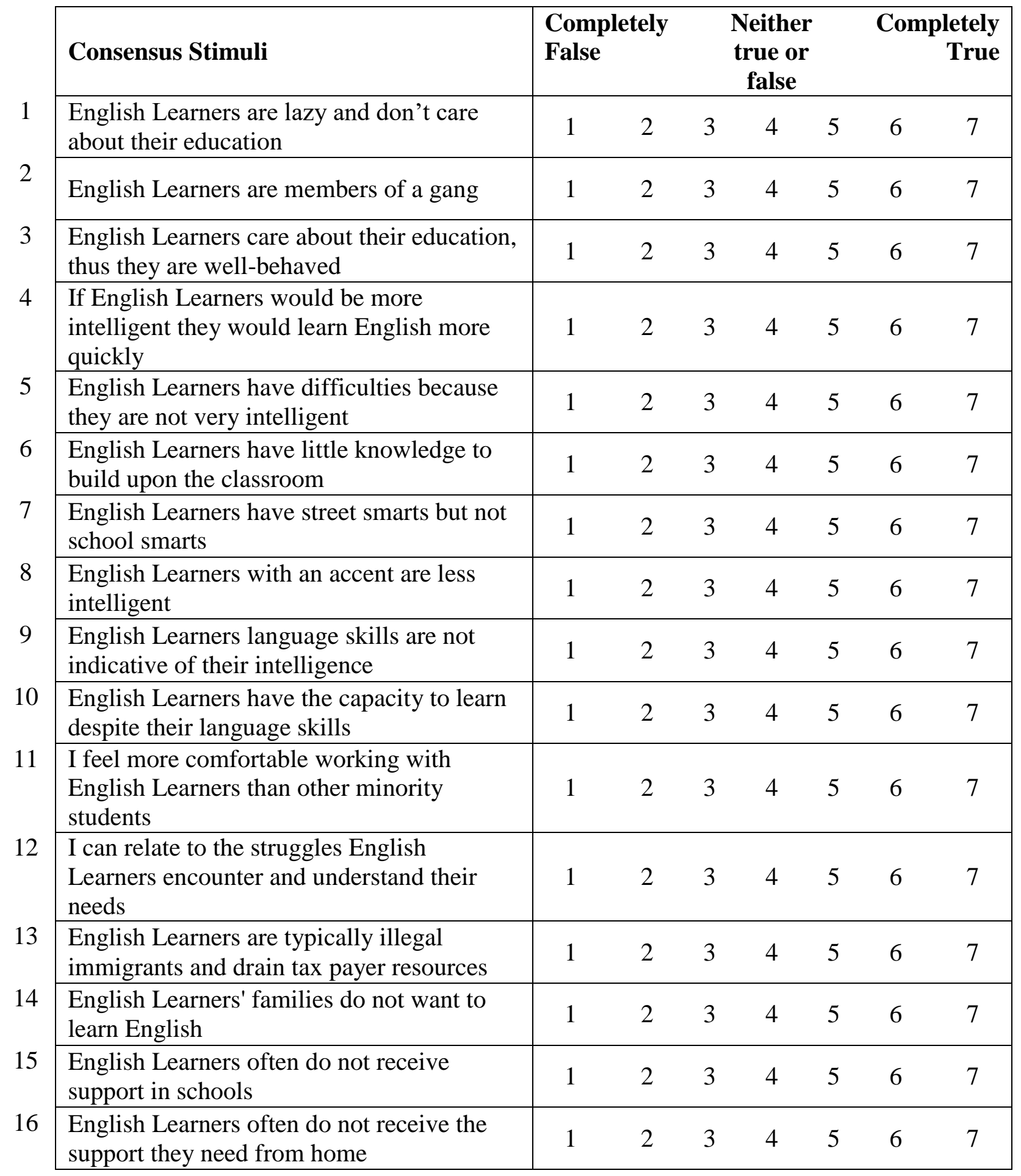




\begin{tabular}{|c|c|c|c|c|c|c|c|}
\hline \multirow{2}{*}{$\begin{array}{l}\text { Consensus Stimuli } \\
\text { English Learners tend to go to the worst } \\
\text { schools, and the worst schools have the } \\
\text { most English Learners }\end{array}$} & \multicolumn{2}{|c|}{$\begin{array}{l}\text { Completely } \\
\text { False }\end{array}$} & \multicolumn{3}{|c|}{$\begin{array}{l}\text { Neither } \\
\text { true or } \\
\text { false }\end{array}$} & \multicolumn{2}{|c|}{$\begin{array}{r}\text { Completely } \\
\text { True }\end{array}$} \\
\hline & 1 & 2 & 3 & 4 & 5 & 6 & 7 \\
\hline English Learners are poor & 1 & 2 & 3 & 4 & 5 & 6 & 7 \\
\hline $\begin{array}{l}\text { English Learners come from low income } \\
\text { families }\end{array}$ & 1 & 2 & 3 & 4 & 5 & 6 & 7 \\
\hline $\begin{array}{l}\text { The faster English Learners students } \\
\text { assimilate the better of they will be }\end{array}$ & 1 & 2 & 3 & 4 & 5 & 6 & 7 \\
\hline $\begin{array}{l}\text { The more English Learners insist in } \\
\text { maintaining their culture and language the } \\
\text { slower they will be to assimilate and learn } \\
\text { English and/or the worst off they will be }\end{array}$ & 1 & 2 & 3 & 4 & 5 & 6 & 7 \\
\hline $\begin{array}{l}\text { English Learners are at a higher risk for } \\
\text { behavioral and/or learning difficulties }\end{array}$ & 1 & 2 & 3 & 4 & 5 & 6 & 7 \\
\hline $\begin{array}{l}\text { English Learners' teachers should not be } \\
\text { held accountable for their achievement }\end{array}$ & 1 & 2 & 3 & 4 & 5 & 6 & 7 \\
\hline $\begin{array}{l}\text { English Learners are so far behind they will } \\
\text { never catch up }\end{array}$ & 1 & 2 & 3 & 4 & 5 & 6 & 7 \\
\hline $\begin{array}{l}\text { Teachers have low expectations from } \\
\text { English Learners }\end{array}$ & 1 & 2 & 3 & 4 & 5 & 6 & 7 \\
\hline $\begin{array}{l}\text { English Learner students are more } \\
\text { motivated to succeed than many of their } \\
\text { native English-speaking peers }\end{array}$ & 1 & 2 & 3 & 4 & 5 & 6 & 7 \\
\hline $\begin{array}{l}\text { English Learners will be academically } \\
\text { successful, and are just as capable of going } \\
\text { to college as native English speakers }\end{array}$ & 1 & 2 & 3 & 4 & 5 & 6 & 7 \\
\hline $\begin{array}{l}\text { Mainstream teachers are responsible for } \\
\text { English Learners' achievement }\end{array}$ & 1 & 2 & 3 & 4 & 5 & 6 & 7 \\
\hline $\begin{array}{l}\text { Teachers should not see color/race in the } \\
\text { classroom }\end{array}$ & 1 & 2 & 3 & 4 & 5 & 6 & 7 \\
\hline I desire to teach English Learner students & 1 & 2 & 3 & 4 & 5 & 6 & 7 \\
\hline $\begin{array}{l}\text { English Learner students' families expose } \\
\text { them to a wide range of cultural experiences }\end{array}$ & 1 & 2 & 3 & 4 & 5 & 6 & 7 \\
\hline $\begin{array}{l}\text { English Learner students are not exposed to } \\
\text { cultural enriching experiences by their } \\
\text { families }\end{array}$ & 1 & 2 & 3 & 4 & 5 & 6 & 7 \\
\hline $\begin{array}{l}\text { English Learners knowledge is due to their } \\
\text { enriching cultural experiences }\end{array}$ & 1 & 2 & 3 & 4 & 5 & 6 & 7 \\
\hline
\end{tabular}




\begin{tabular}{|c|c|c|c|c|c|c|c|}
\hline Consensus Stimuli & \multicolumn{2}{|c|}{$\begin{array}{l}\text { Completely } \\
\text { False }\end{array}$} & \multicolumn{3}{|c|}{$\begin{array}{l}\text { Neither } \\
\text { true or } \\
\text { false }\end{array}$} & \multicolumn{2}{|c|}{$\begin{array}{r}\text { Completely } \\
\text { True }\end{array}$} \\
\hline $\begin{array}{l}\text { English Learner students are not exposed to } \\
\text { cultural enriching experiences by their } \\
\text { families }\end{array}$ & 1 & 2 & 3 & 4 & 5 & 6 & 7 \\
\hline $\begin{array}{l}\text { It is important for mainstream teacher to } \\
\text { understand and know how English Learner } \\
\text { parents' view schools and learning }\end{array}$ & 1 & 2 & 3 & 4 & 5 & 6 & 7 \\
\hline $\begin{array}{l}\text { English Learner students have many } \\
\text { strengths that they bring with them into the } \\
\text { classroom }\end{array}$ & 1 & 2 & 3 & 4 & 5 & 6 & 7 \\
\hline $\begin{array}{l}\text { English Learner students will succeed in } \\
\text { school when mainstream teachers affirm } \\
\text { their cultural identities }\end{array}$ & 1 & 2 & 3 & 4 & 5 & 6 & 7 \\
\hline $\begin{array}{l}\text { English Learners parents do not care about } \\
\text { education and don't want their children } \\
\text { learning English }\end{array}$ & 1 & 2 & 3 & 4 & 5 & 6 & 7 \\
\hline $\begin{array}{l}\text { English Learner's parents want their } \\
\text { children to learn English and/or be bilingual }\end{array}$ & 1 & 2 & 3 & 4 & 5 & 6 & 7 \\
\hline $\begin{array}{l}\text { English Learners struggle because their } \\
\text { parents do not care about their education }\end{array}$ & 1 & 2 & 3 & 4 & 5 & 6 & 7 \\
\hline English Learners have unhappy home lives & 1 & 2 & 3 & 4 & 5 & 6 & 7 \\
\hline $\begin{array}{l}\text { English Learners can't speak their native } \\
\text { language correctly }\end{array}$ & 1 & 2 & 3 & 4 & 5 & 6 & 7 \\
\hline $\begin{array}{l}\text { English Learners can't speak standard } \\
\text { English }\end{array}$ & 1 & 2 & 3 & 4 & 5 & 6 & 7 \\
\hline $\begin{array}{l}\text { English Learners have weaker language } \\
\text { skills }\end{array}$ & 1 & 2 & 3 & 4 & 5 & 6 & 7 \\
\hline $\begin{array}{l}\text { English Learners need to be immersed in } \\
\text { English-only }\end{array}$ & 1 & 2 & 3 & 4 & 5 & 6 & 7 \\
\hline $\begin{array}{l}\text { Keeping and strengthening native language } \\
\text { skills (L1) of English Learners helps their } \\
\text { ability to learn English }\end{array}$ & 1 & 2 & 3 & 4 & 5 & 6 & 7 \\
\hline $\begin{array}{l}\text { All students in the United States should } \\
\text { learn to speak more than one language }\end{array}$ & 1 & 2 & 3 & 4 & 5 & 6 & 7 \\
\hline Bilingualism benefits English Learners & 1 & 2 & 3 & 4 & 5 & 6 & 7 \\
\hline $\begin{array}{l}\text { Bilingual students have stronger higher- } \\
\text { level thinking skills than students who only } \\
\text { speak English }\end{array}$ & 1 & 2 & 3 & 4 & 5 & 6 & 7 \\
\hline $\begin{array}{l}\text { English Learners should not be placed in a } \\
\text { regular classroom until they are fluent in } \\
\text { English }\end{array}$ & 1 & 2 & 3 & 4 & 5 & 6 & 7 \\
\hline
\end{tabular}




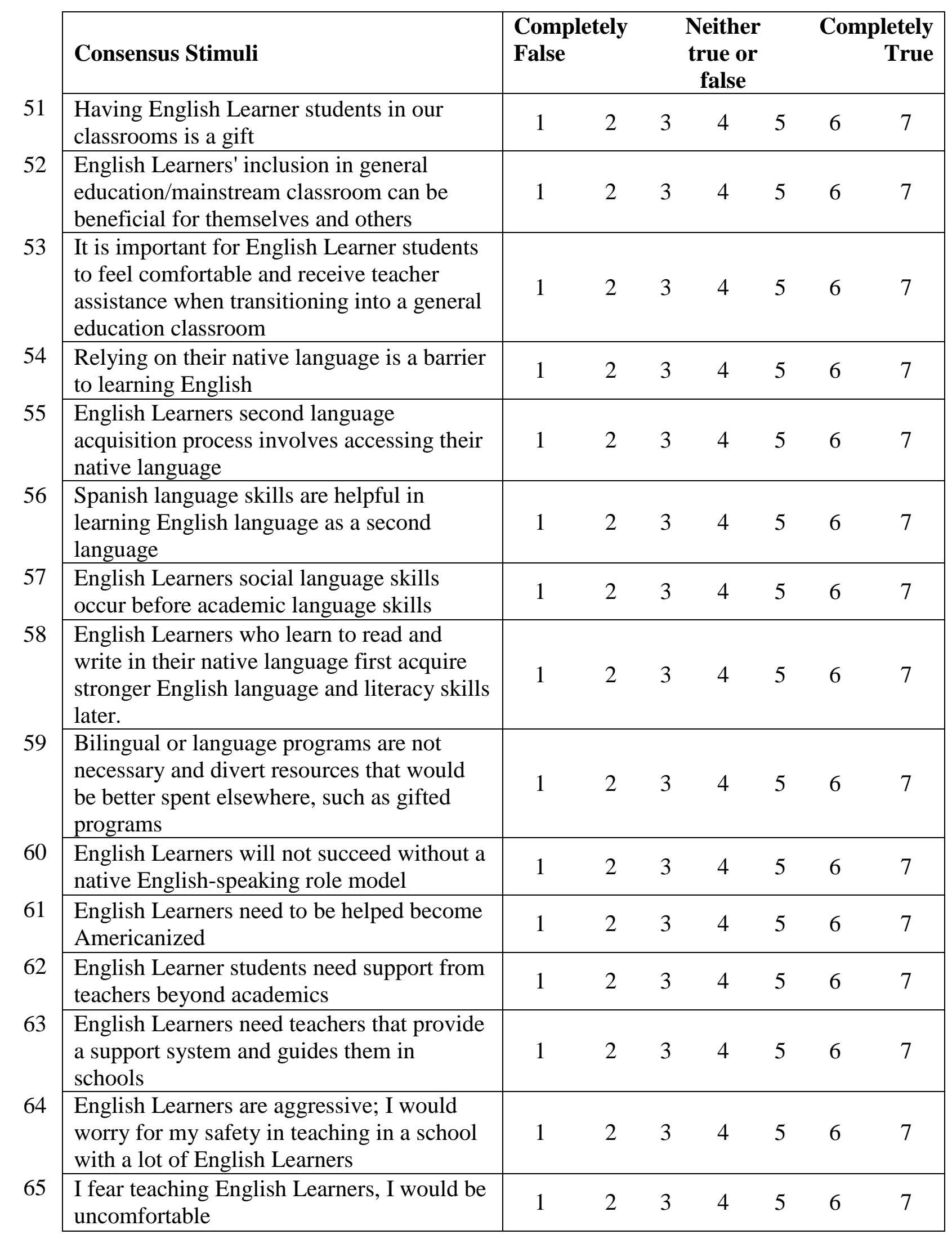




\begin{tabular}{|c|c|c|c|c|c|c|c|c|}
\hline \multirow[b]{2}{*}{6} & \multirow{2}{*}{\begin{tabular}{|l} 
Consensus Stimuli \\
I feel prepared in teaching English Learners
\end{tabular}} & \multicolumn{2}{|c|}{\begin{tabular}{|l} 
Completely \\
False
\end{tabular}} & \multicolumn{3}{|c|}{$\begin{array}{c}\text { Neither } \\
\text { true or } \\
\text { false }\end{array}$} & \multicolumn{2}{|c|}{$\begin{array}{r}\text { Completely } \\
\text { True }\end{array}$} \\
\hline & & 1 & 2 & 3 & 4 & 5 & 6 & 7 \\
\hline 7 & $\begin{array}{l}\text { Teachers' racism impacts English Learners } \\
\text { achievement }\end{array}$ & 1 & 2 & 3 & 4 & 5 & 6 & 7 \\
\hline 8 & $\begin{array}{l}\text { Only teachers of color can be effective } \\
\text { teaching English Learners or relate to } \\
\text { English Learner students }\end{array}$ & 1 & 2 & 3 & 4 & 5 & 6 & 7 \\
\hline 9 & $\begin{array}{l}\text { I prefer to teach students from similar } \\
\text { backgrounds as me. }\end{array}$ & 1 & 2 & 3 & 4 & 5 & 6 & 7 \\
\hline 0 & $\begin{array}{l}\text { Cultural and linguistic differences between } \\
\text { students and teachers inhibits effective } \\
\text { education of English Learners }\end{array}$ & 1 & 2 & 3 & 4 & 5 & 6 & 7 \\
\hline 1 & $\begin{array}{l}\text { Most teachers are not prepared in working } \\
\text { with English Learners }\end{array}$ & 1 & 2 & 3 & 4 & 5 & 6 & 7 \\
\hline 2 & $\begin{array}{l}\text { Teachers need special training in working } \\
\text { with English Learners }\end{array}$ & 1 & 2 & 3 & 4 & 5 & 6 & 7 \\
\hline 3 & $\begin{array}{l}\text { Most teachers don't want to work with } \\
\text { English Learners }\end{array}$ & 1 & 2 & 3 & 4 & 5 & 6 & 7 \\
\hline 4 & $\begin{array}{l}\text { Training all teachers to work with English } \\
\text { Learners is a waste of resources }\end{array}$ & 1 & 2 & 3 & 4 & 5 & 6 & 7 \\
\hline 5 & $\begin{array}{l}\text { English Learners need teachers that can } \\
\text { create culturally inclusive learning materials }\end{array}$ & 1 & 2 & 3 & 4 & 5 & 6 & 7 \\
\hline 6 & $\begin{array}{l}\text { I know specific strategies for designing } \\
\text { instruction that is responsive to students' } \\
\text { language needs }\end{array}$ & 1 & 2 & 3 & 4 & 5 & 6 & 7 \\
\hline 7 & $\begin{array}{l}\text { I know specific strategies for designing } \\
\text { instruction that is responsive to students' } \\
\text { cultural differences }\end{array}$ & 1 & 2 & 3 & 4 & 5 & 6 & 7 \\
\hline 8 & $\begin{array}{l}\text { Teachers lack awareness about English } \\
\text { Learners }\end{array}$ & 1 & 2 & 3 & 4 & 5 & 6 & 7 \\
\hline 9 & $\begin{array}{l}\text { Majority of English Learners speak Spanish } \\
\text { and come from Mexico }\end{array}$ & 1 & 2 & 3 & 4 & 5 & 6 & 7 \\
\hline 0 & $\begin{array}{l}\text { English Learners from Spanish-speaking } \\
\text { countries tend to be more difficult to work } \\
\text { with than students from European countries }\end{array}$ & 1 & 2 & 3 & 4 & 5 & 6 & 7 \\
\hline 1 & All English Learners are students of color & 1 & 2 & 3 & 4 & 5 & 6 & 7 \\
\hline 2 & $\begin{array}{l}\text { Teaching English Learners is a difficult and } \\
\text { scary experience }\end{array}$ & 1 & 2 & 3 & 4 & 5 & 6 & 7 \\
\hline J & $\begin{array}{l}\text { Teaching English Learners is a challenging } \\
\text { and rewarding experience }\end{array}$ & 1 & 2 & 3 & 4 & 5 & 6 & 7 \\
\hline
\end{tabular}




\begin{tabular}{|c|c|c|c|c|c|c|c|c|}
\hline \multirow[b]{2}{*}{84} & \multirow{2}{*}{$\begin{array}{l}\text { Consensus Stimuli } \\
\begin{array}{l}\text { Teaching English Learners has made me a } \\
\text { better teacher }\end{array}\end{array}$} & \multicolumn{2}{|c|}{$\begin{array}{l}\text { Completely } \\
\text { False }\end{array}$} & \multicolumn{3}{|c|}{$\begin{array}{c}\text { Neither } \\
\text { true or } \\
\text { false } \\
\end{array}$} & \multicolumn{2}{|c|}{$\begin{array}{r}\text { Completely } \\
\text { True }\end{array}$} \\
\hline & & 1 & 2 & 3 & 4 & 5 & 6 & 7 \\
\hline 85 & $\begin{array}{l}\text { Teaching English Learners is an empathy } \\
\text { building experience }\end{array}$ & 1 & 2 & 3 & 4 & 5 & 6 & 7 \\
\hline 86 & $\begin{array}{l}\text { I look forward to having English Learner } \\
\text { students in my classroom }\end{array}$ & 1 & 2 & 3 & 4 & 5 & 6 & 7 \\
\hline 87 & $\begin{array}{l}\text { I have worked with a lot of English Learner } \\
\text { students }\end{array}$ & 1 & 2 & 3 & 4 & 5 & 6 & 7 \\
\hline 88 & $\begin{array}{l}\text { I have had the opportunity to develop close } \\
\text { relationships with English Learner students } \\
\text { and/or their families }\end{array}$ & 1 & 2 & 3 & 4 & 5 & 6 & 7 \\
\hline 89 & $\begin{array}{l}\text { Teaching language minority students } \\
\text { successfully means above all challenging } \\
\text { one's attitudes toward the students, their } \\
\text { languages and cultures, and their } \\
\text { communities }\end{array}$ & 1 & 2 & 3 & 4 & 5 & 6 & 7 \\
\hline 90 & $\begin{array}{l}\text { The low achievement of English Learner } \\
\text { students often is the result of negative } \\
\text { teacher attitudes towards them }\end{array}$ & 1 & 2 & 3 & 4 & 5 & 6 & 7 \\
\hline 91 & $\begin{array}{l}\text { Teachers should differentiate instruction } \\
\text { and assessment for English Learners }\end{array}$ & 1 & 2 & 3 & 4 & 5 & 6 & 7 \\
\hline 92 & $\begin{array}{l}\text { It is the responsibility of teachers to be } \\
\text { aware of the language diversity of learners } \\
\text { in their classrooms and to structure their } \\
\text { lessons, as well as adjust their teaching } \\
\text { styles, to meet these students' needs }\end{array}$ & 1 & 2 & 3 & 4 & 5 & 6 & 7 \\
\hline 93 & $\begin{array}{l}\text { English Learner students deserve more } \\
\text { support and caring teachers in schools }\end{array}$ & 1 & 2 & 3 & 4 & 5 & 6 & 7 \\
\hline
\end{tabular}




\section{APPENDIX E: CRITICAL CONSCIOUSNESS SCALE}

Diemer, Rapa, Park, \& Perry (2017)

Instructions: Please respond to the following statements by circling how much you agree or disagree with each statement. For each statement, choose "Strongly Disagree," "Mostly Disagree," "Slightly Disagree," "Slightly Agree," "Mostly Agree," or "Strongly Agree."

$\begin{array}{cccccc}\begin{array}{c}\text { Strongly } \\ \text { Disagree }\end{array} & \begin{array}{c}\text { Mostly } \\ \text { Disagree }\end{array} & \begin{array}{c}\text { Slightly } \\ \text { Disagree }\end{array} & \begin{array}{c}\text { Slightly } \\ \text { Agree }\end{array} & \begin{array}{c}\text { Mostly } \\ \text { Agree }\end{array} & \begin{array}{c}\text { Strongly } \\ \text { Agree }\end{array} \\ 1 & 2 & 3 & 4 & 5 & 6\end{array}$

1. Certain racial or ethnic groups have fewer chances to get a good high school education
1
2
3
4
5
6

2. Poor children have fewer chances to get a good high school education
1
2
3
4
5
6

3. Certain racial or ethnic groups have fewer chances to get good jobs

1 2 3

4

5

6

4. Women have fewer chances to get good jobs
1
2
3
4
5
6

5. Poor people have fewer chances to get good jobs
1
2
3
4
5
6

6. Certain racial or ethnic groups have fewer chances to get ahead

1

2

3

4

5

6

7. Women have fewer chances to get ahead

1

2

3

4

5

6 
8. Poor people have fewer chances to get ahead
1
2
3
4
5
6

9. It is a good thing that certain groups are at the top and other groups are at the bottom
1
2
3
4
5
6

10. It would be good if groups could be equal
1
2
3
4
5
6

11. Group equality should be our ideal
1
2
3
4
5
6

12. All groups should be given an equal chance in life
1
2
3
4
5
6

13. We would have fewer problems if we treated people more equally
1
2
3
4
5
6

Instructions: Please respond to the following statements by circling how often you were involved in each activity in the last year. For each statement, choose "Never did this," "Once or twice last year," "Once every few months," "At least once a month," or "At least once a week."
Never did this
1
Once or twice
last year
2
Once every few months
3

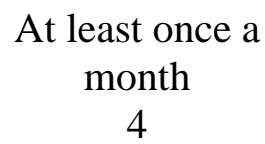

4

4

5

15. Participated in a political party, club, or organization
2
3
4

5 
16. Wrote a letter to a school or community newspaper or publication about a social or political issue
1
2
3
4
5

17. Contacted a public official by phone, mail, or email to tell him/her how you felt about a particular social or political issue
1
2
3
4
5

18. Joined in a protest march, political demonstration, or political meeting
1
2
3
4
5

19. Worked on a political campaign
1
2
3
4
5

20. Participated in a discussion about a social or political issue

$\begin{array}{lllll}1 & 2 & 3 & 4 & 5\end{array}$

21. Signed an email or written petition about a social or political issue
1
2
3
4
5

22. Participated in a human rights, gay rights, or women's rights organization or group
1
3
4

2 


\section{APPENDIX F: CARD-SORTING TASK PILE NAMES}

\begin{tabular}{|c|c|c|c|}
\hline Participant & $\begin{array}{l}\text { Duration } \\
\text { (minutes) }\end{array}$ & Pile \# & Pile Name \\
\hline \multirow[t]{8}{*}{001} & 12 & 1 & my specific roll in interacting with English Learners \\
\hline & & 2 & family attributes to English Learners \\
\hline & & 3 & cultural assets that identify (loosley) students who are \\
\hline & & & English learners \\
\hline & & 4 & What English Learners "need" \\
\hline & & 5 & $\begin{array}{l}\text { impact of the school, teacher, programs offered by } \\
\text { educators to English Learners }\end{array}$ \\
\hline & & 6 & Linguistic factors that impact English Learners \\
\hline & & 7 & "results" of high frequency of English Learners \\
\hline \multirow[t]{3}{*}{002} & 14 & 1 & Things I believe to be true statements \\
\hline & & 2 & $\begin{array}{l}\text { Things I believe are true, but I need/want to incorporate } \\
\text { into my teaching }\end{array}$ \\
\hline & & 3 & Things I believe to be wrong or ignorant statements \\
\hline \multirow[t]{3}{*}{003} & 14 & 1 & Positive \\
\hline & & 2 & Negative \\
\hline & & 3 & Neutral or Needed More Info \\
\hline \multirow[t]{3}{*}{004} & 8 & 1 & More positive suggestion \\
\hline & & 2 & Negative saying \\
\hline & & 3 & Stereotypes \\
\hline \multirow[t]{4}{*}{005} & 9 & 1 & Empathy approach \\
\hline & & 2 & "Americanization" method -waste of time \\
\hline & & 3 & learning about the student as a whole \\
\hline & & 4 & EL's are stereotyped and disregarded \\
\hline \multirow[t]{11}{*}{006} & 8 & 1 & Strategies \\
\hline & & 2 & Teachers jobs/views \\
\hline & & 3 & instruction \\
\hline & & 4 & negative statements about EL's \\
\hline & & 5 & assimilation, skills EL's bring to the classroom \\
\hline & & 6 & all students \\
\hline & & 7 & motivation \\
\hline & & 8 & Spanish \\
\hline & & 9 & positive statements about EL's \\
\hline & & 10 & language acquisition \\
\hline & & 11 & relatability \\
\hline \multirow[t]{3}{*}{007} & 12 & 1 & Teacher statements \\
\hline & & 2 & False statements \\
\hline & & 3 & True statements \\
\hline \multirow[t]{2}{*}{008} & 31 & 1 & $\begin{array}{l}\text { Assumptions/Misconceptions Regarding Specifically } \\
\text { ELL }\end{array}$ \\
\hline & & 2 & Misconceptions Regarding Race/Ethnicity \\
\hline
\end{tabular}




\begin{tabular}{|c|c|c|c|}
\hline & & 3 & Positive Instructional Strategies \\
\hline & & 4 & Assimilationist Views of ELL Students \\
\hline & & 5 & $\begin{array}{l}\text { Lack of important care of ELL Students/Negative } \\
\text { teacher attitude }\end{array}$ \\
\hline & & 6 & Straight Up deficit view of ELL students \\
\hline & & 7 & Struggles/Challenges ELL Students face \\
\hline & & 8 & $\begin{array}{l}\text { Positive Classroom Benefits in Classes with ELL } \\
\text { Students }\end{array}$ \\
\hline & & 9 & Positive Educator Behaviors towards ELL Students \\
\hline & & 10 & deficit view regarding language only of ELL Students \\
\hline 009 & 11 & 1 & $\begin{array}{l}\text { Affirming/Positive Thinking \& Strategies to help } \\
\text { English Learners }\end{array}$ \\
\hline & & 2 & $\begin{array}{l}\text { Deficit Thinking/Negative Thinking \& Strategies that } \\
\text { hold back English Learners }\end{array}$ \\
\hline & & 3 & Facts about English Learners that may be true or false \\
\hline & & 4 & Personal Statements I relate/agree with \\
\hline & & 5 & Personal Statements I don't relate/agree with \\
\hline 010 & 14 & 1 & Deficit Thinking \\
\hline & & 2 & "I" statements \\
\hline & & 3 & Opinions \\
\hline & & 4 & Facts \\
\hline & & 5 & What teachers can do \\
\hline & & 6 & Positive comments \\
\hline 011 & 10 & 1 & Yes/agree \\
\hline & & 2 & maybe/sometimes/I don't know \\
\hline & & 3 & no/disagree \\
\hline 012 & 9 & 1 & What I believe are true statements \\
\hline & & 2 & Deficit beliefs and stereotypes \\
\hline & & 3 & What I believe are false statements \\
\hline 013 & 11 & 1 & "I" Negative Statements \\
\hline & & 2 & "I" Positive Statements \\
\hline & & 3 & Negative Connotation on teaching ELs \\
\hline & & 4 & Negative about EL parents \\
\hline & & 5 & Positive about EL parents \\
\hline & & 6 & Idea that being bilingual is beneficial \\
\hline & & 7 & Positive thoughts on teaching Bilingual students \\
\hline & & 8 & Negative connotations about ELs \\
\hline 014 & 10 & 1 & What teachers should do \\
\hline & & 2 & General statements $*_{\text {not }}$ positive or negative \\
\hline & & 3 & Positive thoughts about ELL \\
\hline & & 4 & Negative thoughts about ELL \\
\hline 015 & 16 & 1 & Culture assimilation \\
\hline & & 2 & Teacher/student responsibility \\
\hline & & 3 & Teacher confidence on teaching \\
\hline
\end{tabular}




\begin{tabular}{|c|c|c|c|}
\hline & & 4 & ELL success is due to teacher \\
\hline & & 5 & Negative socioeconomic views \\
\hline & & 6 & ELL class is a waste \\
\hline & & 7 & Society's negative views on ELL at risk etc \\
\hline & & 8 & ELL motivation \& success - positive \\
\hline & & 9 & Positive academic views on ELL student \\
\hline & & 10 & Negative society views about ELL students \\
\hline & & 11 & Negative home and family values about ELL students \\
\hline & & 12 & Negative teacher views on ELL students \\
\hline & & 13 & Negative opinion on an ELL teacher \\
\hline & & 14 & Skills used to improve English \\
\hline & & 15 & ELL values \\
\hline & & 16 & What teachers should do for ELL students \\
\hline & & 17 & U.S. ideas \\
\hline & & 18 & Negative attitudes about teaching \\
\hline 016 & 8 & 1 & Personal experiences \\
\hline & & 2 & Do not Agree with \\
\hline & & 3 & Agree with \\
\hline 017 & 11 & 1 & Statements that are neutral/indifferent about \\
\hline & & 2 & Statements I agree with \\
\hline & & 3 & Statements that I disagree with/are opinions \\
\hline 018 & 19 & 1 & Positive classroom environment for ELs \\
\hline & & 2 & Personal teaching statements \\
\hline & & 3 & The strength that culture has one ELs \\
\hline & & 4 & Deficit thinking of ELs \\
\hline 019 & 23 & 1 & Inconclusive \\
\hline & & 2 & Positive \& Truthful \\
\hline & & 3 & False \& Harsh \\
\hline 020 & 32 & 1 & Achievement of ELLs \\
\hline & & 2 & ELLs \& Race \\
\hline & & 3 & Language skills of ELLs \\
\hline & & 4 & Bad things about ELLs/Stereotypes \\
\hline & & 5 & $\begin{array}{l}\text { Positive things about ELLs \& the possible teaching } \\
\text { experiences you can have }\end{array}$ \\
\hline & & 6 & Things I haven't done \\
\hline & & 7 & $\begin{array}{l}\text { Positive things about Bilinguals \& how they can still } \\
\text { succeed (benefits) }\end{array}$ \\
\hline & & 8 & Instruction I do know for ELLs \\
\hline & & 9 & ELLs behavior in the classroom \\
\hline & & 10 & Lack of teacher knowledge for ELLs \\
\hline & & 11 & Support of ELLs in school \\
\hline & & 12 & Teachers who are ignorant and uninformed about ELLs \\
\hline & & 13 & Culture \\
\hline 021 & 10 & 1 & Neutral/not sure \\
\hline
\end{tabular}




\begin{tabular}{|c|c|c|c|}
\hline & & 2 & TRUE \\
\hline & & 3 & FALSE \\
\hline \multirow[t]{5}{*}{022} & 16 & 1 & School/Building as a Whole \\
\hline & & 2 & Student \\
\hline & & 3 & Teacher POV \\
\hline & & 4 & Family \\
\hline & & 5 & Negative \\
\hline \multirow[t]{4}{*}{023} & 14 & 1 & Facts: Could be written in a study or article \\
\hline & & 2 & Opinion- Negative \\
\hline & & 3 & Opinion- More Positive \\
\hline & & 4 & Professional Preferences (Opinions) \\
\hline \multirow[t]{7}{*}{024} & 14 & 1 & Teacher Responsibilities \\
\hline & & 2 & Teacher challenges teaching ELLs \\
\hline & & 3 & Classroom/Academic Concerns teaching ELL learners \\
\hline & & 4 & Personal Perceptions of Working with ELLs \\
\hline & & 5 & ELL Strengths \\
\hline & & 6 & Cultural/Language Concerns teaching ELLs \\
\hline & & 7 & Negative Stereotypes \\
\hline \multirow[t]{6}{*}{025} & 18 & 1 & "I" Statements \\
\hline & & 2 & Positive \\
\hline & & 3 & Family/Culture \\
\hline & & 4 & Teachers \\
\hline & & 5 & Neutral \\
\hline & & 6 & Negative \\
\hline \multirow[t]{7}{*}{026} & 20 & 1 & Things we've been taught \\
\hline & & 2 & Positive \\
\hline & & 3 & Absolutes \\
\hline & & 4 & Bossy- Opinionated People \\
\hline & & 5 & Whatever Pile \\
\hline & & 6 & Things that would help ELs be successful \\
\hline & & 7 & Opinions Negative \\
\hline \multirow[t]{6}{*}{027} & 19 & 1 & Skills/tools gained \\
\hline & & 2 & Undecided pile because of specific cases \\
\hline & & 3 & Policies \\
\hline & & 4 & My experiences with ELLs \\
\hline & & 5 & $\begin{array}{l}\text { Teaching improvement to make ELLs learning } \\
\text { experience better }\end{array}$ \\
\hline & & 6 & Negative perspective/views/attitudes about ELL \\
\hline \multirow[t]{6}{*}{028} & 24 & 1 & Positive assumptions \\
\hline & & 2 & Negative assumptions \\
\hline & & 3 & Supports \\
\hline & & 4 & Strongly ignorant teacher attitudes \\
\hline & & 5 & Aware yet ignorant teacher attitude \\
\hline & & 6 & Realistic aware positive teacher attitude \\
\hline
\end{tabular}


7 Very aware but extreme teacher attitude past realistic/aware/positive

\begin{tabular}{|c|c|c|c|}
\hline \multirow[t]{10}{*}{029} & \multirow[t]{10}{*}{22} & 1 & If this happened, it would be lovely \\
\hline & & 2 & Negative perceptions of ELL \\
\hline & & 3 & Ability to learn \& receive education \\
\hline & & 4 & Support \\
\hline & & 5 & Thoughts on ELL families \\
\hline & & 6 & Thoughts on how ELL learn \\
\hline & & 7 & Perceptions of how teachers connect/relate to ELL \\
\hline & & 8 & Cultural identities \\
\hline & & 9 & Professional learning strategies \\
\hline & & 10 & Statements a teacher may make \\
\hline \multirow[t]{11}{*}{030} & \multirow[t]{11}{*}{29} & 1 & Other languages are important \\
\hline & & 2 & Accusation that teacher lack awareness about ELs \\
\hline & & 3 & Americanized \\
\hline & & 4 & Fear \\
\hline & & 5 & "I know" \\
\hline & & 6 & Skills are important \\
\hline & & 7 & $\begin{array}{l}\text { Hope/All students in the U.S. should learn to speak more } \\
\text { than one language }\end{array}$ \\
\hline & & 8 & Looking forward to having ELs in my classroom \\
\hline & & 9 & ELs are culturally enriched \\
\hline & & 10 & Pressure of teachers \\
\hline & & 11 & Judgment Day (in negative way) \\
\hline \multirow[t]{3}{*}{031} & \multirow[t]{3}{*}{8} & 1 & Agree \\
\hline & & 2 & Disagree \\
\hline & & 3 & Debatable depends on other factors \\
\hline \multirow[t]{2}{*}{032} & \multirow[t]{2}{*}{17} & 1 & Teacher \\
\hline & & 2 & English Learner \\
\hline \multirow[t]{9}{*}{033} & \multirow[t]{9}{*}{33} & 1 & Negative thoughts about ELs in school \\
\hline & & 2 & Things teachers need to do for ELs \\
\hline & & 3 & Thoughts teachers want to have \\
\hline & & 4 & Things that shouldn't happen \\
\hline & & 5 & Negative thoughts about teachers teaching ELs \\
\hline & & 6 & Things said about ELs family \\
\hline & & 7 & Dumb \\
\hline & & 8 & $\begin{array}{l}\text { Common initial/negative thoughts people generally have } \\
\text { about ELs }\end{array}$ \\
\hline & & 9 & Thoughts all teachers need about ELs \\
\hline \multirow[t]{3}{*}{034} & \multirow[t]{3}{*}{66} & 1 & $\begin{array}{l}\text { Negative aspects of teachers towards students that are } \\
\text { not ELs- drawbacks }\end{array}$ \\
\hline & & 2 & Optimistic outlook on teaching EL students \\
\hline & & 3 & $\begin{array}{l}\text { What teachers should do \& should not do \& their } \\
\text { responsibilities }\end{array}$ \\
\hline
\end{tabular}


$4 \quad$ Teaching immersion classroom- Pros

5 Pros (opinions on) of being bilingual

6 Personal aspirations of ELL teacher who has already worked with students

7 Against bilingualism

8 Comfort zones of teacher that has worked as an EL teacher

9 Opinions based on Personal ELL teacher experiences

10 Subjective negative views

11 Racial slurs- Racial discrimination

12 Teachers and how they view students from a racial point

13 More positive outlook on ELLs parents' views on education

14 Cultural immersion

15 Pros \& Cons from the home acquiring English language fluency

16 Language

17 Intelligence- Speaking a 2nd language (non English) viewed as a demoted person

18 Relationship between dominant language \& acquisition of English as a 2nd language

19 ELs are intelligent

20 Prejudice Racist

21 Behavioral issues

\begin{tabular}{lll}
\hline 035 & 1 & Unsure \\
& 25 & All students deserve this \\
& 3 & About me as a teacher and I don't agree \\
& 4 & About me as a teacher \& I agree \\
& 5 & About teaching ELLs and I agree \\
& 6 & Personal belief \& I agree \\
& 7 & About ELLs \& I agree \\
& 8 & About teachers \& I agree \\
& 9 & Kind of \\
& 10 & About ELLs \& I don't agree- It's Racist \& not CLR \& \\
& 18 & makes me sick \\
& & Negative teaching myths \\
& 2 & Instructional/teaching ELLs for positive outcomes \\
& 3 & Research based facts about ELLs \\
& 4 & My experiences \\
& 5 & Opinions \\
& 6 & Myths about ELLs \\
& 1 & Stereotypes about EL behavior \& identity \\
& 2 & Stereotypes about where EL students come from \\
& 3 & Misconceptions of intelligence of EL students \\
& 4 & Stereotypes on negative outlook of teaching EL
\end{tabular}




\begin{tabular}{|c|c|c|c|}
\hline & & 5 & Empowering EL experience \\
\hline & & 6 & Assimilation \\
\hline & & 7 & Teacher responsibilities \\
\hline & & 8 & EL parent misconceptions \\
\hline & & 9 & Positive outlooks on a diverse classroom \\
\hline & & 10 & Bilingualism language skills \\
\hline & & 11 & Support from teachers \\
\hline & & 12 & Benefits of diverse multi-lingual classroom \\
\hline & & 13 & What often happens with EL students... \\
\hline & & 14 & About EL student/parent motivation to succeed \\
\hline & & 15 & Teacher experiences \\
\hline & & 16 & Cultural experiences \\
\hline 038 & 23 & 1 & Depende- on the situation \\
\hline & & 2 & Systemic Problems \\
\hline & & 3 & English Learner descriptors \\
\hline & & 4 & Positive teacher traits \\
\hline & & 5 & Negative teacher traits \\
\hline & & 6 & Teaching strategies/methods \\
\hline & & 7 & Benefits of bilingualism \\
\hline & & 8 & Negative perceptions/Falsehoods \\
\hline 039 & 21 & 1 & Personal goals as a teacher \\
\hline & & 2 & Teacher's self-imposed barriers \\
\hline & & 3 & Negative ideas of cultural assimilation \\
\hline & & 4 & Bilingualism leads to success \\
\hline & & 5 & Unfair to teaching professionalism \\
\hline & & 6 & Wrong career \\
\hline & & 7 & Family goals \\
\hline & & 8 & Untrue statements \\
\hline 040 & 17 & 1 & Personal opinions/statements \\
\hline & & 2 & Opinions related to socioeconomic status \\
\hline & & 3 & Negative opinions based on stereotypes \\
\hline & & 4 & $\begin{array}{l}\text { Statements based on teacher experiences and } \\
\text { administrators }\end{array}$ \\
\hline & & 5 & Attitudes: positive or negative when working with ELs \\
\hline
\end{tabular}

Note: Participants 001-020 are Pre-service teachers, Participants 021-040 are In-service teachers 
APPENDIX G: MDSCAL CONFIGURATION - DIMENSION 1 RANKINGS

\begin{tabular}{|c|c|c|c|}
\hline Card \# & Category & Statement Text & Dim. 1 \\
\hline $\mathrm{C} 35$ & Culture Influence & $\begin{array}{l}\text { It is important for mainstream teacher to understand } \\
\text { and know how English Learner parents' view schools } \\
\text { and learning }\end{array}$ & -1.898 \\
\hline C92 & $\begin{array}{l}\text { Differentiated } \\
\text { Instruction }\end{array}$ & $\begin{array}{l}\text { It is the responsibility of teachers to be aware of the } \\
\text { language diversity of learners in their classrooms and } \\
\text { to structure their lessons, as well as adjust their } \\
\text { teaching styles, to meet these students' needs }\end{array}$ & -1.893 \\
\hline $\mathrm{C} 83$ & $\begin{array}{l}\text { Experience } \\
\text { teaching ELs }\end{array}$ & $\begin{array}{l}\text { Teaching English Learners is a challenging and } \\
\text { rewarding experience }\end{array}$ & -1.892 \\
\hline $\mathrm{C} 53$ & Inclusion & $\begin{array}{l}\text { It is important for English Learner students to feel } \\
\text { comfortable and receive teacher assistance when } \\
\text { transitioning into a general education classroom }\end{array}$ & -1.833 \\
\hline $\mathrm{C} 72$ & $\begin{array}{l}\text { Culturally } \\
\text { Responsive }\end{array}$ & $\begin{array}{l}\text { Teachers need special training in working with } \\
\text { English Learners }\end{array}$ & -1.819 \\
\hline C52 & Inclusion & $\begin{array}{l}\text { English Learners' inclusion in general } \\
\text { education/mainstream classroom can be beneficial } \\
\text { for themselves and others }\end{array}$ & -1.819 \\
\hline $\mathrm{C} 36$ & $\begin{array}{c}\text { Cultural } \\
\text { Capital/Deprived }\end{array}$ & $\begin{array}{l}\text { English Learner students have many strengths that } \\
\text { they bring with them into the classroom }\end{array}$ & -1.819 \\
\hline $\mathrm{C} 75$ & $\begin{array}{l}\text { Training \& } \\
\text { Culturally } \\
\text { Responsive }\end{array}$ & $\begin{array}{l}\text { English Learners need teachers that can create } \\
\text { culturally inclusive learning materials }\end{array}$ & -1.814 \\
\hline $\mathrm{C} 27$ & $\begin{array}{l}\text { Achievement \& } \\
\text { Expectations }\end{array}$ & $\begin{array}{l}\text { English Learners will be academically successful, } \\
\text { and are just as capable of going to college as native } \\
\text { English speakers }\end{array}$ & -1.801 \\
\hline $\mathrm{C} 10$ & Intelligence & $\begin{array}{l}\text { English Learners have the capacity to learn despite } \\
\text { their language skills }\end{array}$ & -1.795 \\
\hline $\mathrm{C} 48$ & Language Skills & Bilingualism benefits English Learners & -1.752 \\
\hline C37 & $\begin{array}{c}\text { Cultural } \\
\text { Capital/Deprived }\end{array}$ & $\begin{array}{l}\text { English Learner students will succeed in school } \\
\text { when mainstream teachers affirm their cultural } \\
\text { identities }\end{array}$ & -1.738 \\
\hline $\mathrm{C} 86$ & $\begin{array}{l}\text { Experience } \\
\text { teaching ELs }\end{array}$ & $\begin{array}{l}\text { I look forward to having English Learner students in } \\
\text { my classroom }\end{array}$ & -1.734 \\
\hline $\mathrm{C} 30$ & Color-Blind & I desire to teach English Learner student & -1.708 \\
\hline $\mathrm{C} 63$ & White-Savior & $\begin{array}{l}\text { English Learners need teachers that provide a } \\
\text { support system and guides them in schools }\end{array}$ & -1.702 \\
\hline C56 & $\begin{array}{l}\text { Language Learning } \\
\text { Process }\end{array}$ & $\begin{array}{l}\text { Spanish language skills are helpful in learning } \\
\text { English language as a second language }\end{array}$ & -1.665 \\
\hline $\mathrm{C} 84$ & $\begin{array}{l}\text { Experience } \\
\text { teaching ELs }\end{array}$ & $\begin{array}{l}\text { Teaching English Learners has made me a better } \\
\text { teacher }\end{array}$ & -1.644 \\
\hline $\mathrm{C} 28$ & $\begin{array}{l}\text { Achievement \& } \\
\text { Expectations }\end{array}$ & $\begin{array}{l}\text { Mainstream teachers are responsible for English } \\
\text { Learners' achievement }\end{array}$ & -1.625 \\
\hline
\end{tabular}




\begin{tabular}{|c|c|c|c|}
\hline $\mathrm{C} 89$ & $\begin{array}{l}\text { Educational } \\
\text { Challenges }\end{array}$ & $\begin{array}{l}\text { Teaching language minority students successfully } \\
\text { means above all challenging one's attitudes toward } \\
\text { the students, their languages and cultures, and their } \\
\text { communities }\end{array}$ & -1.619 \\
\hline $\mathrm{C} 51$ & Inclusion & $\begin{array}{l}\text { Having English Learner students in our classrooms is } \\
\text { a gift }\end{array}$ & -1.619 \\
\hline C91 & $\begin{array}{l}\text { Differentiated } \\
\text { Instruction }\end{array}$ & $\begin{array}{l}\text { Teachers should differentiate instruction and } \\
\text { assessment for English Learners }\end{array}$ & -1.564 \\
\hline C58 & $\begin{array}{c}\text { Language Learning } \\
\text { Process }\end{array}$ & $\begin{array}{l}\text { English Learners who learn to read and write in their } \\
\text { native language first acquire stronger English } \\
\text { language and literacy skills later. }\end{array}$ & -1.396 \\
\hline C46 & Language skills & $\begin{array}{l}\text { Keeping and strengthening native language skills } \\
\text { (L1) of English Learners helps their ability to learn } \\
\text { English }\end{array}$ & -1.370 \\
\hline $\mathrm{C} 47$ & Language Skills & $\begin{array}{l}\text { All students in the United States should learn to } \\
\text { speak more than one language }\end{array}$ & -1.359 \\
\hline $\mathrm{C} 77$ & $\begin{array}{l}\text { Training \& } \\
\text { Culturally } \\
\text { Responsive }\end{array}$ & $\begin{array}{l}\text { I know specific strategies for designing instruction } \\
\text { that is responsive to students' cultural differences }\end{array}$ & -1.355 \\
\hline C76 & $\begin{array}{l}\text { Training \& } \\
\text { Culturally } \\
\text { Responsive }\end{array}$ & $\begin{array}{l}\text { I know specific strategies for designing instruction } \\
\text { that is responsive to students' language needs }\end{array}$ & -1.336 \\
\hline $\mathrm{C} 93$ & $\begin{array}{l}\text { Equitable } \\
\text { Education }\end{array}$ & $\begin{array}{l}\text { English Learner students deserve more support and } \\
\text { caring teachers in schools }\end{array}$ & -1.290 \\
\hline C62 & White-Savior & $\begin{array}{l}\text { English Learner students need support from teachers } \\
\text { beyond academics }\end{array}$ & -1.275 \\
\hline $\mathrm{C} 85$ & $\begin{array}{l}\text { Experience } \\
\text { teaching ELs }\end{array}$ & $\begin{array}{l}\text { Teaching English Learners is an empathy building } \\
\text { experience }\end{array}$ & -1.253 \\
\hline $\mathrm{C} 31$ & Culture Influence & $\begin{array}{l}\text { English Learner students' families expose them to a } \\
\text { wide range of cultural experiences }\end{array}$ & -1.156 \\
\hline $\mathrm{C} 88$ & $\begin{array}{l}\text { Experience } \\
\text { teaching ELs }\end{array}$ & $\begin{array}{l}\text { I have had the opportunity to develop close } \\
\text { relationships with English Learner students and/or } \\
\text { their families }\end{array}$ & -1.142 \\
\hline $\mathrm{C} 87$ & $\begin{array}{l}\text { Experience } \\
\text { teaching ELs }\end{array}$ & I have worked with a lot of English Learner students & -1.087 \\
\hline C39 & Parents Influence & $\begin{array}{l}\text { English Learner's parents want their children to learn } \\
\text { English and/or be bilingual }\end{array}$ & -1.071 \\
\hline $\mathrm{C} 09$ & Intelligence & $\begin{array}{l}\text { English Learners language skills are not indicative of } \\
\text { their intelligence }\end{array}$ & -1.069 \\
\hline C55 & $\begin{array}{l}\text { Language Learning } \\
\text { Process }\end{array}$ & $\begin{array}{l}\text { English Learners second language acquisition } \\
\text { process involves accessing their native language }\end{array}$ & -1.035 \\
\hline $\mathrm{C} 57$ & $\begin{array}{l}\text { Language Learning } \\
\text { Process }\end{array}$ & $\begin{array}{l}\text { English Learners social language skills occur before } \\
\text { academic language skills }\end{array}$ & -1.001 \\
\hline $\mathrm{C} 03$ & $\begin{array}{l}\text { Personality \& } \\
\text { Behavior }\end{array}$ & $\begin{array}{l}\text { English Learners care about their education, thus } \\
\text { they are well-behaved }\end{array}$ & -0.945 \\
\hline
\end{tabular}




\begin{tabular}{|c|c|c|c|}
\hline C67 & Racism & $\begin{array}{l}\text { Teachers' racism impacts English Learners } \\
\text { achievement }\end{array}$ & -0.900 \\
\hline C49 & Language Skills & $\begin{array}{l}\text { Bilingual students have stronger higher-level } \\
\text { thinking skills than students who only speak English }\end{array}$ & -0.893 \\
\hline $\mathrm{C} 33$ & Culture Influence & $\begin{array}{l}\text { English Learners knowledge is due to their enriching } \\
\text { cultural experiences }\end{array}$ & -0.884 \\
\hline C66 & $\begin{array}{l}\text { Fear of English } \\
\text { Learners }\end{array}$ & I feel prepared in teaching English Learners & -0.851 \\
\hline $\mathrm{C} 12$ & $\begin{array}{l}\text { Relate to English } \\
\text { Learners }\end{array}$ & $\begin{array}{l}\text { I can relate to the struggles English Learners } \\
\text { encounter and understand their needs }\end{array}$ & -0.724 \\
\hline $\mathrm{C} 26$ & $\begin{array}{l}\text { Achievement \& } \\
\text { Expectations }\end{array}$ & $\begin{array}{l}\text { English Learner students are more motivated to } \\
\text { succeed than many of their native English-speaking } \\
\text { peers }\end{array}$ & -0.707 \\
\hline $\mathrm{C} 78$ & Unawareness & Teachers lack awareness about English Learners & -0.512 \\
\hline $\mathrm{C} 71$ & $\begin{array}{l}\text { Training \& } \\
\text { Culturally } \\
\text { Responsive }\end{array}$ & $\begin{array}{l}\text { Most teachers are not prepared in working with } \\
\text { English Learners }\end{array}$ & -0.364 \\
\hline $\mathrm{C} 90$ & $\begin{array}{l}\text { Educational } \\
\text { Challenges }\end{array}$ & $\begin{array}{l}\text { The low achievement of English Learner students } \\
\text { often is the result of negative teacher attitudes } \\
\text { towards them }\end{array}$ & -0.313 \\
\hline C11 & $\begin{array}{l}\text { Relate to English } \\
\text { Learners }\end{array}$ & $\begin{array}{l}\text { I feel more comfortable working with English } \\
\text { Learners than other minority students }\end{array}$ & -0.221 \\
\hline C15 & $\begin{array}{l}\text { Segregation \& Lack } \\
\text { of Support }\end{array}$ & $\begin{array}{l}\text { English Learners often do not receive support in } \\
\text { schools }\end{array}$ & -0.129 \\
\hline $\mathrm{C} 29$ & $\begin{array}{l}\text { Achievement \& } \\
\text { Expectations }\end{array}$ & $\begin{array}{l}\text { Mainstream teachers are responsible for English } \\
\text { Learners' achievement }\end{array}$ & 0.286 \\
\hline $\mathrm{C} 25$ & $\begin{array}{l}\text { Achievement \& } \\
\text { Expectations }\end{array}$ & $\begin{array}{l}\text { Teachers have low expectations from English } \\
\text { Learners }\end{array}$ & 0.602 \\
\hline $\mathrm{C} 70$ & $\begin{array}{c}\text { Language \& } \\
\text { Cultural Collisions }\end{array}$ & $\begin{array}{l}\text { Cultural and linguistic differences between students } \\
\text { and teachers inhibits effective education of English } \\
\text { Learners }\end{array}$ & 0.772 \\
\hline $\mathrm{C} 20$ & Assimilation & $\begin{array}{l}\text { The faster English Learners students assimilate the } \\
\text { better of they will be }\end{array}$ & 0.847 \\
\hline $\mathrm{C} 16$ & $\begin{array}{c}\text { Segregation \& Lack } \\
\text { of Support }\end{array}$ & $\begin{array}{l}\text { English Learners often do not receive the support } \\
\text { they need from home }\end{array}$ & 1.051 \\
\hline $\mathrm{C} 79$ & $\begin{array}{l}\text { Origin of English } \\
\text { Learners }\end{array}$ & $\begin{array}{l}\text { Majority of English Learners speak Spanish and } \\
\text { come from Mexico }\end{array}$ & 1.063 \\
\hline $\mathrm{C} 73$ & $\begin{array}{l}\text { Training \& } \\
\text { Culturally } \\
\text { Responsive }\end{array}$ & $\begin{array}{l}\text { Most teachers don't want to work with English } \\
\text { Learners }\end{array}$ & 1.140 \\
\hline $\mathrm{C} 69$ & $\begin{array}{c}\text { Language \& } \\
\text { Cultural Collisions }\end{array}$ & $\begin{array}{l}\text { I prefer to teach students from similar backgrounds } \\
\text { as me. }\end{array}$ & 1.169 \\
\hline $\mathrm{C} 23$ & $\begin{array}{l}\text { Achievement \& } \\
\text { Expectations }\end{array}$ & $\begin{array}{l}\text { English Learners' teachers should not be held } \\
\text { accountable for their achievement }\end{array}$ & 1.190 \\
\hline
\end{tabular}




\begin{tabular}{|c|c|c|c|}
\hline $\mathrm{C} 82$ & $\begin{array}{l}\text { Experience } \\
\text { teaching ELs }\end{array}$ & $\begin{array}{l}\text { Teaching English Learners is a difficult and scary } \\
\text { experience }\end{array}$ & 1.194 \\
\hline C65 & $\begin{array}{l}\text { Fear of English } \\
\text { Learners }\end{array}$ & $\begin{array}{l}\text { I fear teaching English Learners, I would be } \\
\text { uncomfortable }\end{array}$ & 1.304 \\
\hline $\mathrm{C} 22$ & At-Risk & $\begin{array}{l}\text { English Learners are at a higher risk for behavioral } \\
\text { and/or learning difficulties }\end{array}$ & 1.306 \\
\hline $\mathrm{C} 74$ & $\begin{array}{l}\text { Training \& } \\
\text { Culturally } \\
\text { Responsive }\end{array}$ & $\begin{array}{l}\text { Training all teachers to work with English Learners } \\
\text { is a waste of resources }\end{array}$ & 1.321 \\
\hline C60 & White-Savior & $\begin{array}{l}\text { English Learners will not succeed without a native } \\
\text { English-speaking role model }\end{array}$ & 1.391 \\
\hline $\mathrm{C} 50$ & Inclusion & $\begin{array}{l}\text { English Learners should not be placed in a regular } \\
\text { classroom until they are fluent in English }\end{array}$ & 1.409 \\
\hline C68 & $\begin{array}{c}\text { Language \& } \\
\text { Cultural Collisions }\end{array}$ & $\begin{array}{l}\text { Only teachers of color can be effective teaching } \\
\text { English Learners or relate to English Learner } \\
\text { students }\end{array}$ & 1.448 \\
\hline $\mathrm{C} 38$ & Parents Influence & $\begin{array}{l}\text { English Learners parents do not care about education } \\
\text { and don't want their children learning English }\end{array}$ & 1.520 \\
\hline $\mathrm{C} 81$ & $\begin{array}{l}\text { Origin of English } \\
\text { Learners }\end{array}$ & All English Learners are students of color & 1.526 \\
\hline $\mathrm{C} 45$ & Language skills & $\begin{array}{l}\text { English Learners need to be immersed in English- } \\
\text { only }\end{array}$ & 1.527 \\
\hline $\mathrm{C} 14$ & Immigration & $\begin{array}{l}\text { English Learners' families do not want to learn } \\
\text { English }\end{array}$ & 1.534 \\
\hline C59 & Bilingual Programs & $\begin{array}{l}\text { Bilingual or language programs are not necessary } \\
\text { and divert resources that would be better spent } \\
\text { elsewhere, such as gifted programs }\end{array}$ & 1.547 \\
\hline $\mathrm{C} 44$ & Language Skills & English Learners have weaker language skills & 1.574 \\
\hline C54 & $\begin{array}{l}\text { Language Learning } \\
\text { Process }\end{array}$ & $\begin{array}{l}\text { Relying on their native language is a barrier to } \\
\text { learning English }\end{array}$ & 1.575 \\
\hline $\mathrm{C} 43$ & Language Skills & English Learners can't speak standard English & 1.582 \\
\hline C61 & White-Savior & $\begin{array}{l}\text { English Learners need to be helped become } \\
\text { Americanized }\end{array}$ & 1.584 \\
\hline $\mathrm{C} 41$ & Home Life & English Learners have unhappy home lives & 1.587 \\
\hline $\mathrm{C} 80$ & $\begin{array}{l}\text { Origin of English } \\
\text { Learners }\end{array}$ & $\begin{array}{l}\text { English Learners from Spanish-speaking countries } \\
\text { tend to be more difficult to work with than students } \\
\text { from European countries }\end{array}$ & 1.593 \\
\hline $\mathrm{C} 06$ & Intelligence & $\begin{array}{l}\text { English Learners have little knowledge to build upon } \\
\text { the classroom }\end{array}$ & 1.597 \\
\hline $\mathrm{C} 42$ & Language Skills & $\begin{array}{l}\text { English Learners can't speak their native language } \\
\text { correctly }\end{array}$ & 1.609 \\
\hline $\mathrm{C} 02$ & $\begin{array}{c}\text { Personality \& } \\
\text { Behavior }\end{array}$ & English Learners are members of a gang & 1.615 \\
\hline $\mathrm{C} 32$ & Culture Influence & $\begin{array}{l}\text { English Learner students are not exposed to cultural } \\
\text { enriching experiences by their families }\end{array}$ & 1.616 \\
\hline
\end{tabular}




\begin{tabular}{|c|c|c|c|}
\hline $\mathrm{C} 01$ & $\begin{array}{l}\text { Personality \& } \\
\text { Behavior }\end{array}$ & $\begin{array}{l}\text { English Learners are lazy and don't care about their } \\
\text { education }\end{array}$ & 1.621 \\
\hline $\mathrm{C} 40$ & Parents Influence & $\begin{array}{l}\text { English Learners struggle because their parents do } \\
\text { not care about their education }\end{array}$ & 1.625 \\
\hline $\mathrm{C} 05$ & Intelligence & $\begin{array}{l}\text { English Learners have difficulties because they are } \\
\text { not very intelligent }\end{array}$ & 1.626 \\
\hline C19 & Assimilation & English Learners come from low income families & 1.628 \\
\hline $\mathrm{C} 08$ & Intelligence & English Learners with an accent are less intelligent & 1.629 \\
\hline $\mathrm{C} 07$ & Intelligence & $\begin{array}{l}\text { English Learners have street smarts but not school } \\
\text { smarts }\end{array}$ & 1.631 \\
\hline $\mathrm{C} 04$ & Intelligence & $\begin{array}{l}\text { If English Learners would be more intelligent they } \\
\text { would learn English more quickly }\end{array}$ & 1.635 \\
\hline $\mathrm{C} 24$ & $\begin{array}{l}\text { Achievement \& } \\
\text { Expectations }\end{array}$ & $\begin{array}{l}\text { English Learners are so far behind they will never } \\
\text { catch up }\end{array}$ & 1.637 \\
\hline $\mathrm{C} 21$ & Assimilation & $\begin{array}{l}\text { The more English Learners insist in maintaining their } \\
\text { culture and language the slower they will be to } \\
\text { assimilate and learn English and/or the worst off they } \\
\text { will be }\end{array}$ & 1.643 \\
\hline $\mathrm{C} 18$ & Assimilation & English Learners are poor & 1.652 \\
\hline $\mathrm{C} 13$ & Immigration & $\begin{array}{l}\text { English Learners are typically illegal immigrants and } \\
\text { drain tax payer resources }\end{array}$ & 1.653 \\
\hline $\mathrm{C} 17$ & $\begin{array}{l}\text { Segregation \& Lack } \\
\text { of Support }\end{array}$ & $\begin{array}{l}\text { English Learners tend to go to the worst schools, and } \\
\text { the worst schools have the most English Learners }\end{array}$ & 1.665 \\
\hline C64 & $\begin{array}{l}\text { Fear of English } \\
\text { Learners }\end{array}$ & $\begin{array}{l}\text { English Learners are aggressive; I would worry for } \\
\text { my safety in teaching in a school with a lot of } \\
\text { English Learners }\end{array}$ & 1.666 \\
\hline
\end{tabular}


APPENDIX H: MDSCAL CONFIGURATION - DIMENSION 2 RANKINGS

\begin{tabular}{|c|c|c|c|}
\hline Card \# & Category & Statement Text & Dim. 2 \\
\hline $\mathrm{C} 26$ & $\begin{array}{l}\text { Achievement \& } \\
\text { Expectations }\end{array}$ & $\begin{array}{l}\text { English Learner students are more motivated to } \\
\text { succeed than many of their native English-speaking } \\
\text { peers }\end{array}$ & -1.521 \\
\hline C55 & $\begin{array}{c}\text { Language Learning } \\
\text { Process }\end{array}$ & $\begin{array}{l}\text { English Learners second language acquisition process } \\
\text { involves accessing their native language }\end{array}$ & -1.480 \\
\hline $\mathrm{C} 03$ & $\begin{array}{l}\text { Personality \& } \\
\text { Behavior }\end{array}$ & $\begin{array}{l}\text { English Learners care about their education, thus they } \\
\text { are well-behaved }\end{array}$ & -1.396 \\
\hline C49 & Language Skills & $\begin{array}{l}\text { Bilingual students have stronger higher-level thinking } \\
\text { skills than students who only speak English }\end{array}$ & -1.343 \\
\hline C57 & $\begin{array}{l}\text { Language Learning } \\
\text { Process }\end{array}$ & $\begin{array}{l}\text { English Learners social language skills occur before } \\
\text { academic language skills }\end{array}$ & -1.312 \\
\hline C58 & $\begin{array}{l}\text { Language Learning } \\
\text { Process }\end{array}$ & $\begin{array}{l}\text { English Learners who learn to read and write in their } \\
\text { native language first acquire stronger English } \\
\text { language and literacy skills later. }\end{array}$ & -1.312 \\
\hline $\mathrm{C} 33$ & Culture Influence & $\begin{array}{l}\text { English Learners knowledge is due to their enriching } \\
\text { cultural experiences }\end{array}$ & -1.082 \\
\hline $\mathrm{C} 46$ & Language skills & $\begin{array}{l}\text { Keeping and strengthening native language skills } \\
\text { (L1) of English Learners helps their ability to learn } \\
\text { English }\end{array}$ & -1.067 \\
\hline $\mathrm{C} 31$ & Culture Influence & $\begin{array}{l}\text { English Learner students' families expose them to a } \\
\text { wide range of cultural experiences }\end{array}$ & -1.033 \\
\hline C62 & White-Savior & $\begin{array}{l}\text { English Learner students need support from teachers } \\
\text { beyond academics }\end{array}$ & -0.950 \\
\hline $\mathrm{C} 15$ & $\begin{array}{c}\text { Segregation \& Lack } \\
\text { Support }\end{array}$ & $\begin{array}{l}\text { English Learners often do not receive support in } \\
\text { schools }\end{array}$ & -0.882 \\
\hline C56 & $\begin{array}{l}\text { Language Learning } \\
\text { Process }\end{array}$ & $\begin{array}{l}\text { Spanish language skills are helpful in learning } \\
\text { English language as a second language }\end{array}$ & -0.834 \\
\hline C39 & Parents Influence & $\begin{array}{l}\text { English Learner's parents want their children to learn } \\
\text { English and/or be bilingual }\end{array}$ & -0.825 \\
\hline $\mathrm{C} 16$ & $\begin{array}{l}\text { Segregation \& Lack o } \\
\text { Support }\end{array}$ & $\begin{array}{l}\text { English Learners often do not receive the support } \\
\text { they need from home }\end{array}$ & -0.698 \\
\hline $\mathrm{C} 09$ & Intelligence & $\begin{array}{l}\text { English Learners language skills are not indicative of } \\
\text { their intelligence }\end{array}$ & -0.689 \\
\hline $\mathrm{C} 27$ & $\begin{array}{c}\text { Achievement \& } \\
\text { Expectations }\end{array}$ & $\begin{array}{l}\text { English Learners will be academically successful, } \\
\text { and are just as capable of going to college as native } \\
\text { English speakers }\end{array}$ & -0.642 \\
\hline $\mathrm{C} 10$ & Intelligence & $\begin{array}{l}\text { English Learners have the capacity to learn despite } \\
\text { their language skills }\end{array}$ & -0.615 \\
\hline $\mathrm{C} 47$ & Language Skills & $\begin{array}{l}\text { All students in the United States should learn to } \\
\text { speak more than one language }\end{array}$ & -0.608 \\
\hline $\mathrm{C} 48$ & Language Skills & Bilingualism benefits English Learners & -0.594 \\
\hline
\end{tabular}




\begin{tabular}{|c|c|c|c|}
\hline C63 & White-Savior & $\begin{array}{l}\text { English Learners need teachers that provide a support } \\
\text { system and guides them in schools }\end{array}$ & -0.587 \\
\hline $\mathrm{C} 22$ & At-Risk & $\begin{array}{l}\text { English Learners are at a higher risk for behavioral } \\
\text { and/or learning difficulties }\end{array}$ & -0.544 \\
\hline C79 & $\begin{array}{l}\text { Origin of English } \\
\text { Learners }\end{array}$ & $\begin{array}{l}\text { Majority of English Learners speak Spanish and } \\
\text { come from Mexico }\end{array}$ & -0.512 \\
\hline $\mathrm{C} 90$ & $\begin{array}{l}\text { Educational } \\
\text { Challenges }\end{array}$ & $\begin{array}{l}\text { The low achievement of English Learner students } \\
\text { often is the result of negative teacher attitudes } \\
\text { towards them }\end{array}$ & -0.502 \\
\hline $\mathrm{C} 70$ & $\begin{array}{l}\text { Language \& Cultural } \\
\text { Collisions }\end{array}$ & $\begin{array}{l}\text { Cultural and linguistic differences between students } \\
\text { and teachers inhibits effective education of English } \\
\text { Learners }\end{array}$ & -0.486 \\
\hline $\mathrm{C} 36$ & $\begin{array}{c}\text { Cultural } \\
\text { Capital/Deprived }\end{array}$ & $\begin{array}{l}\text { English Learner students have many strengths that } \\
\text { they bring with them into the classroom }\end{array}$ & -0.472 \\
\hline $\mathrm{C} 37$ & $\begin{array}{c}\text { Cultural } \\
\text { Capital/Deprived }\end{array}$ & $\begin{array}{l}\text { English Learner students will succeed in school when } \\
\text { mainstream teachers affirm their cultural identities }\end{array}$ & -0.466 \\
\hline C52 & Inclusion & $\begin{array}{l}\text { English Learners' inclusion in general } \\
\text { education/mainstream classroom can be beneficial for } \\
\text { themselves and others }\end{array}$ & -0.462 \\
\hline $\mathrm{C} 32$ & Culture Influence & $\begin{array}{l}\text { English Learner students are not exposed to cultural } \\
\text { enriching experiences by their families }\end{array}$ & -0.405 \\
\hline C93 & Equitable Education & $\begin{array}{l}\text { English Learner students deserve more support and } \\
\text { caring teachers in schools }\end{array}$ & -0.384 \\
\hline $\mathrm{C} 53$ & Inclusion & $\begin{array}{l}\text { It is important for English Learner students to feel } \\
\text { comfortable and receive teacher assistance when } \\
\text { transitioning into a general education classroom }\end{array}$ & -0.346 \\
\hline $\mathrm{C} 44$ & Language Skills & English Learners have weaker language skills & -0.320 \\
\hline $\mathrm{C} 14$ & Immigration & $\begin{array}{l}\text { English Learners' families do not want to learn } \\
\text { English }\end{array}$ & -0.309 \\
\hline $\mathrm{C} 41$ & Home Life & English Learners have unhappy home lives & -0.308 \\
\hline $\mathrm{C} 43$ & Language Skills & English Learners can't speak standard English & -0.304 \\
\hline $\mathrm{C} 75$ & $\begin{array}{l}\text { Training \& Culturally } \\
\text { Responsive }\end{array}$ & $\begin{array}{l}\text { English Learners need teachers that can create } \\
\text { culturally inclusive learning materials }\end{array}$ & -0.273 \\
\hline $\mathrm{C} 20$ & Assimilation & $\begin{array}{l}\text { The faster English Learners students assimilate the } \\
\text { better of they will be }\end{array}$ & -0.258 \\
\hline $\mathrm{C} 45$ & Language skills & $\begin{array}{l}\text { English Learners need to be immersed in English- } \\
\text { only }\end{array}$ & -0.229 \\
\hline $\mathrm{C} 54$ & $\begin{array}{l}\text { Language Learning } \\
\text { Process }\end{array}$ & $\begin{array}{l}\text { Relying on their native language is a barrier to } \\
\text { learning English }\end{array}$ & -0.221 \\
\hline $\mathrm{C} 18$ & Assimilation & English Learners are poor & -0.160 \\
\hline C19 & Assimilation & English Learners come from low income families & -0.152 \\
\hline $\mathrm{C} 42$ & Language Skills & $\begin{array}{l}\text { English Learners can't speak their native language } \\
\text { correctly }\end{array}$ & -0.140 \\
\hline
\end{tabular}




\begin{tabular}{|c|c|c|c|}
\hline $\mathrm{C} 38$ & Parents Influence & $\begin{array}{l}\text { English Learners parents do not care about education } \\
\text { and don't want their children learning English }\end{array}$ & -0.065 \\
\hline C71 & $\begin{array}{l}\text { Training \& Culturally } \\
\text { Responsive }\end{array}$ & $\begin{array}{l}\text { Most teachers are not prepared in working with } \\
\text { English Learners }\end{array}$ & -0.062 \\
\hline C61 & White-Savior & $\begin{array}{l}\text { English Learners need to be helped become } \\
\text { Americanized }\end{array}$ & -0.050 \\
\hline $\mathrm{C} 06$ & Intelligence & $\begin{array}{l}\text { English Learners have little knowledge to build upon } \\
\text { the classroom }\end{array}$ & -0.015 \\
\hline $\mathrm{C} 07$ & Intelligence & $\begin{array}{l}\text { English Learners have street smarts but not school } \\
\text { smarts }\end{array}$ & -0.002 \\
\hline C60 & White-Savior & $\begin{array}{l}\text { English Learners will not succeed without a native } \\
\text { English-speaking role model }\end{array}$ & 0.001 \\
\hline $\mathrm{C} 81$ & $\begin{array}{l}\text { Origin of English } \\
\text { Learners }\end{array}$ & All English Learners are students of color & 0.007 \\
\hline $\mathrm{C} 80$ & $\begin{array}{l}\text { Origin of English } \\
\text { Learners }\end{array}$ & $\begin{array}{l}\text { English Learners from Spanish-speaking countries } \\
\text { tend to be more difficult to work with than students } \\
\text { from European countries }\end{array}$ & 0.016 \\
\hline $\mathrm{C} 08$ & Intelligence & English Learners with an accent are less intelligent & 0.018 \\
\hline $\mathrm{C} 05$ & Intelligence & $\begin{array}{l}\text { English Learners have difficulties because they are } \\
\text { not very intelligent }\end{array}$ & 0.020 \\
\hline $\mathrm{C} 40$ & Parents Influence & $\begin{array}{l}\text { English Learners struggle because their parents do } \\
\text { not care about their education }\end{array}$ & 0.047 \\
\hline $\mathrm{C} 04$ & Intelligence & $\begin{array}{l}\text { If English Learners would be more intelligent they } \\
\text { would learn English more quickly }\end{array}$ & 0.050 \\
\hline C64 & $\begin{array}{l}\text { Fear of English } \\
\text { Learners }\end{array}$ & $\begin{array}{l}\text { English Learners are aggressive; I would worry for } \\
\text { my safety in teaching in a school with a lot of English } \\
\text { Learners }\end{array}$ & 0.052 \\
\hline C50 & Inclusion & $\begin{array}{l}\text { English Learners should not be placed in a regular } \\
\text { classroom until they are fluent in English }\end{array}$ & 0.056 \\
\hline $\mathrm{C} 78$ & Unawareness & Teachers lack awareness about English Learners & 0.062 \\
\hline $\mathrm{C} 24$ & $\begin{array}{l}\text { Achievement \& } \\
\text { Expectations }\end{array}$ & $\begin{array}{l}\text { English Learners are so far behind they will never } \\
\text { catch up }\end{array}$ & 0.064 \\
\hline $\mathrm{C} 21$ & Assimilation & $\begin{array}{l}\text { The more English Learners insist in maintaining their } \\
\text { culture and language the slower they will be to } \\
\text { assimilate and learn English and/or the worst off they } \\
\text { will be }\end{array}$ & 0.074 \\
\hline $\mathrm{C} 01$ & $\begin{array}{c}\text { Personality \& } \\
\text { Behavior }\end{array}$ & $\begin{array}{l}\text { English Learners are lazy and don't care about their } \\
\text { education }\end{array}$ & 0.074 \\
\hline $\mathrm{C} 13$ & Immigration & $\begin{array}{l}\text { English Learners are typically illegal immigrants and } \\
\text { drain tax payer resources }\end{array}$ & 0.084 \\
\hline $\mathrm{C} 85$ & $\begin{array}{l}\text { Experience teaching } \\
\text { ELs }\end{array}$ & $\begin{array}{l}\text { Teaching English Learners is an empathy building } \\
\text { experience }\end{array}$ & 0.114 \\
\hline $\mathrm{C} 17$ & $\begin{array}{l}\text { Segregation \& Lack } \\
\text { of Support }\end{array}$ & $\begin{array}{l}\text { English Learners tend to go to the worst schools, and } \\
\text { the worst schools have the most English Learners }\end{array}$ & 0.122 \\
\hline
\end{tabular}




\begin{tabular}{|c|c|c|c|}
\hline C67 & Racism & $\begin{array}{l}\text { Teachers' racism impacts English Learners } \\
\text { achievement }\end{array}$ & 0.150 \\
\hline $\mathrm{C} 02$ & $\begin{array}{l}\text { Personality \& } \\
\text { Behavior }\end{array}$ & English Learners are members of a gang & 0.180 \\
\hline C92 & $\begin{array}{l}\text { Differentiated } \\
\text { Instruction }\end{array}$ & $\begin{array}{l}\text { It is the responsibility of teachers to be aware of the } \\
\text { language diversity of learners in their classrooms and } \\
\text { to structure their lessons, as well as adjust their } \\
\text { teaching styles, to meet these students' needs }\end{array}$ & 0.246 \\
\hline $\mathrm{C} 82$ & $\begin{array}{l}\text { Experience teaching } \\
\text { ELs }\end{array}$ & $\begin{array}{l}\text { Teaching English Learners is a difficult and scary } \\
\text { experience }\end{array}$ & 0.258 \\
\hline C35 & Culture Influence & $\begin{array}{l}\text { It is important for mainstream teacher to understand } \\
\text { and know how English Learner parents' view schools } \\
\text { and learning }\end{array}$ & 0.271 \\
\hline $\mathrm{C} 23$ & $\begin{array}{l}\text { Achievement \& } \\
\text { Expectations }\end{array}$ & $\begin{array}{l}\text { English Learners' teachers should not be held } \\
\text { accountable for their achievement }\end{array}$ & 0.328 \\
\hline $\mathrm{C} 72$ & Culturally Responsive & $\begin{array}{l}\text { Teachers need special training in working with } \\
\text { English Learners }\end{array}$ & 0.336 \\
\hline $\mathrm{C} 25$ & $\begin{array}{l}\text { Achievement \& } \\
\text { Expectations }\end{array}$ & $\begin{array}{l}\text { Teachers have low expectations from English } \\
\text { Learners }\end{array}$ & 0.346 \\
\hline C59 & Bilingual Programs & $\begin{array}{l}\text { Bilingual or language programs are not necessary and } \\
\text { divert resources that would be better spent elsewhere, } \\
\text { such as gifted programs }\end{array}$ & 0.434 \\
\hline $\mathrm{C} 28$ & $\begin{array}{l}\text { Achievement \& } \\
\text { Expectations }\end{array}$ & $\begin{array}{l}\text { Mainstream teachers are responsible for English } \\
\text { Learners' achievement }\end{array}$ & 0.472 \\
\hline C68 & $\begin{array}{l}\text { Language \& Cultural } \\
\text { Collisions }\end{array}$ & $\begin{array}{l}\text { Only teachers of color can be effective teaching } \\
\text { English Learners or relate to English Learner students }\end{array}$ & 0.472 \\
\hline $\mathrm{C} 89$ & $\begin{array}{l}\text { Educational } \\
\text { Challenges }\end{array}$ & $\begin{array}{l}\text { Teaching language minority students successfully } \\
\text { means above all challenging one's attitudes toward } \\
\text { the students, their languages and cultures, and their } \\
\text { communities }\end{array}$ & 0.484 \\
\hline $\mathrm{C} 73$ & $\begin{array}{c}\text { Training \& Culturally } \\
\text { Responsive }\end{array}$ & $\begin{array}{l}\text { Most teachers don't want to work with English } \\
\text { Learners }\end{array}$ & 0.531 \\
\hline C74 & $\begin{array}{l}\text { Training \& Culturally } \\
\text { Responsive }\end{array}$ & $\begin{array}{l}\text { Training all teachers to work with English Learners is } \\
\text { a waste of resources }\end{array}$ & 0.542 \\
\hline C91 & $\begin{array}{l}\text { Differentiated } \\
\text { Instruction }\end{array}$ & $\begin{array}{l}\text { Teachers should differentiate instruction and } \\
\text { assessment for English Learners }\end{array}$ & 0.582 \\
\hline $\mathrm{C} 83$ & $\begin{array}{l}\text { Experience teaching } \\
\text { ELs }\end{array}$ & $\begin{array}{l}\text { Teaching English Learners is a challenging and } \\
\text { rewarding experience }\end{array}$ & 0.708 \\
\hline C51 & Inclusion & $\begin{array}{l}\text { Having English Learner students in our classrooms is } \\
\text { a gift }\end{array}$ & 0.899 \\
\hline $\mathrm{C} 65$ & $\begin{array}{l}\text { Fear of English } \\
\text { Learners }\end{array}$ & $\begin{array}{l}\text { I fear teaching English Learners, I would be } \\
\text { uncomfortable }\end{array}$ & 0.983 \\
\hline $\mathrm{C} 29$ & $\begin{array}{l}\text { Achievement \& } \\
\text { Expectations }\end{array}$ & $\begin{array}{l}\text { Mainstream teachers are responsible for English } \\
\text { Learners' achievement }\end{array}$ & 1.069 \\
\hline
\end{tabular}




\begin{tabular}{|c|c|c|c|}
\hline C69 & $\begin{array}{l}\text { Language \& Cultural } \\
\text { Collisions }\end{array}$ & $\begin{array}{l}\text { I prefer to teach students from similar backgrounds as } \\
\text { me. }\end{array}$ & 1.201 \\
\hline $\mathrm{C} 86$ & $\begin{array}{l}\text { Experience teaching } \\
\text { ELs }\end{array}$ & $\begin{array}{l}\text { I look forward to having English Learner students in } \\
\text { my classroom }\end{array}$ & 1.220 \\
\hline $\mathrm{C} 84$ & $\begin{array}{l}\text { Experience teaching } \\
\text { ELs }\end{array}$ & $\begin{array}{l}\text { Teaching English Learners has made me a better } \\
\text { teacher }\end{array}$ & 1.245 \\
\hline $\mathrm{C} 30$ & Color-Blind & I desire to teach English Learner student & 1.323 \\
\hline C76 & $\begin{array}{l}\text { Training \& Culturally } \\
\text { Responsive }\end{array}$ & $\begin{array}{l}\text { I know specific strategies for designing instruction } \\
\text { that is responsive to students' language needs }\end{array}$ & 1.582 \\
\hline $\mathrm{C} 12$ & $\begin{array}{l}\text { Relate to English } \\
\text { Learners }\end{array}$ & $\begin{array}{l}\text { I can relate to the struggles English Learners } \\
\text { encounter and understand their needs }\end{array}$ & 1.619 \\
\hline C66 & $\begin{array}{l}\text { Fear of English } \\
\text { Learners }\end{array}$ & I feel prepared in teaching English Learners & 1.645 \\
\hline $\mathrm{C} 88$ & $\begin{array}{l}\text { Experience teaching } \\
\text { ELs }\end{array}$ & $\begin{array}{l}\text { I have had the opportunity to develop close } \\
\text { relationships with English Learner students and/or } \\
\text { their families }\end{array}$ & 1.691 \\
\hline C77 & $\begin{array}{l}\text { Training \& Culturally } \\
\text { Responsive }\end{array}$ & $\begin{array}{l}\text { I know specific strategies for designing instruction } \\
\text { that is responsive to students' cultural differences }\end{array}$ & 1.702 \\
\hline $\mathrm{C} 87$ & $\begin{array}{l}\text { Experience teaching } \\
\text { ELs }\end{array}$ & I have worked with a lot of English Learner students & 1.728 \\
\hline $\mathrm{C} 11$ & $\begin{array}{l}\text { Relate to English } \\
\text { Learners }\end{array}$ & $\begin{array}{l}\text { I feel more comfortable working with English } \\
\text { Learners than other minority students }\end{array}$ & 1.807 \\
\hline
\end{tabular}


APPENDIX I: MDSCAL CONFIGURATION - DIMENSION 3 RANKINGS

\begin{tabular}{|c|c|c|c|}
\hline Card \# & Category & Statement Text & Dim. 3 \\
\hline $\mathrm{C} 78$ & Unawareness & Teachers lack awareness about English Learners & -1.706 \\
\hline C71 & $\begin{array}{l}\text { Training \& Culturally } \\
\text { Responsive }\end{array}$ & $\begin{array}{l}\text { Most teachers are not prepared in working with } \\
\text { English Learners }\end{array}$ & -1.547 \\
\hline C90 & $\begin{array}{l}\text { Educational } \\
\text { Challenges }\end{array}$ & $\begin{array}{l}\text { The low achievement of English Learner students } \\
\text { often is the result of negative teacher attitudes } \\
\text { towards them }\end{array}$ & -1.296 \\
\hline $\mathrm{C} 15$ & $\begin{array}{c}\text { Segregation \& Lack } \\
\text { of Support }\end{array}$ & $\begin{array}{l}\text { English Learners often do not receive support in } \\
\text { schools }\end{array}$ & -1.252 \\
\hline C67 & Racism & $\begin{array}{l}\text { Teachers' racism impacts English Learners } \\
\text { achievement }\end{array}$ & -1.219 \\
\hline $\mathrm{C} 29$ & $\begin{array}{l}\text { Achievement \& } \\
\text { Expectations }\end{array}$ & $\begin{array}{l}\text { Mainstream teachers are responsible for English } \\
\text { Learners' achievement }\end{array}$ & -1.019 \\
\hline $\mathrm{C} 28$ & $\begin{array}{l}\text { Achievement \& } \\
\text { Expectations }\end{array}$ & $\begin{array}{l}\text { Mainstream teachers are responsible for English } \\
\text { Learners' achievement }\end{array}$ & -0.995 \\
\hline $\mathrm{C} 25$ & $\begin{array}{l}\text { Achievement \& } \\
\text { Expectations }\end{array}$ & $\begin{array}{l}\text { Teachers have low expectations from English } \\
\text { Learners }\end{array}$ & -0.981 \\
\hline $\mathrm{C} 70$ & $\begin{array}{l}\text { Language \& Cultural } \\
\text { Collisions }\end{array}$ & $\begin{array}{l}\text { Cultural and linguistic differences between } \\
\text { students and teachers inhibits effective education } \\
\text { of English Learners }\end{array}$ & -0.970 \\
\hline $\mathrm{C} 73$ & $\begin{array}{c}\text { Training \& Culturally } \\
\text { Responsive }\end{array}$ & $\begin{array}{l}\text { Most teachers don't want to work with English } \\
\text { Learners }\end{array}$ & -0.905 \\
\hline C62 & White-Savior & $\begin{array}{l}\text { English Learner students need support from } \\
\text { teachers beyond academics }\end{array}$ & -0.818 \\
\hline $\mathrm{C} 72$ & Culturally Responsive & $\begin{array}{l}\text { Teachers need special training in working with } \\
\text { English Learners }\end{array}$ & -0.814 \\
\hline C91 & $\begin{array}{l}\text { Differentiated } \\
\text { Instruction }\end{array}$ & $\begin{array}{l}\text { Teachers should differentiate instruction and } \\
\text { assessment for English Learners }\end{array}$ & -0.804 \\
\hline $\mathrm{C} 82$ & $\begin{array}{l}\text { Experience teaching } \\
\text { ELs }\end{array}$ & $\begin{array}{l}\text { Teaching English Learners is a difficult and scary } \\
\text { experience }\end{array}$ & -0.738 \\
\hline $\mathrm{C} 23$ & $\begin{array}{l}\text { Achievement \& } \\
\text { Expectations }\end{array}$ & $\begin{array}{l}\text { English Learners' teachers should not be held } \\
\text { accountable for their achievement }\end{array}$ & -0.718 \\
\hline C93 & Equitable Education & $\begin{array}{l}\text { English Learner students deserve more support } \\
\text { and caring teachers in schools }\end{array}$ & -0.717 \\
\hline C92 & $\begin{array}{l}\text { Differentiated } \\
\text { Instruction }\end{array}$ & $\begin{array}{l}\text { It is the responsibility of teachers to be aware of } \\
\text { the language diversity of learners in their } \\
\text { classrooms and to structure their lessons, as well } \\
\text { as adjust their teaching styles, to meet these } \\
\text { students' needs }\end{array}$ & -0.645 \\
\hline C74 & $\begin{array}{l}\text { Training \& Culturally } \\
\text { Responsive }\end{array}$ & $\begin{array}{l}\text { Training all teachers to work with English } \\
\text { Learners is a waste of resources }\end{array}$ & -0.641 \\
\hline
\end{tabular}




\begin{tabular}{|c|c|c|c|}
\hline $\mathrm{C} 89$ & $\begin{array}{l}\text { Educational } \\
\text { Challenges }\end{array}$ & $\begin{array}{l}\text { Teaching language minority students successfully } \\
\text { means above all challenging one's attitudes } \\
\text { toward the students, their languages and cultures, } \\
\text { and their communities }\end{array}$ & -0.610 \\
\hline C35 & Culture Influence & $\begin{array}{l}\text { It is important for mainstream teacher to } \\
\text { understand and know how English Learner } \\
\text { parents' view schools and learning }\end{array}$ & -0.610 \\
\hline C37 & $\begin{array}{c}\text { Cultural } \\
\text { Capital/Deprived }\end{array}$ & $\begin{array}{l}\text { English Learner students will succeed in school } \\
\text { when mainstream teachers affirm their cultural } \\
\text { identities }\end{array}$ & -0.589 \\
\hline C63 & White-Savior & $\begin{array}{l}\text { English Learners need teachers that provide a } \\
\text { support system and guides them in schools }\end{array}$ & -0.510 \\
\hline C75 & $\begin{array}{l}\text { Training \& Culturally } \\
\text { Responsive }\end{array}$ & $\begin{array}{l}\text { English Learners need teachers that can create } \\
\text { culturally inclusive learning materials }\end{array}$ & -0.496 \\
\hline C68 & $\begin{array}{l}\text { Language \& Cultural } \\
\text { Collisions }\end{array}$ & $\begin{array}{l}\text { Only teachers of color can be effective teaching } \\
\text { English Learners or relate to English Learner } \\
\text { students }\end{array}$ & -0.487 \\
\hline C53 & Inclusion & $\begin{array}{l}\text { It is important for English Learner students to feel } \\
\text { comfortable and receive teacher assistance when } \\
\text { transitioning into a general education classroom }\end{array}$ & -0.393 \\
\hline C65 & $\begin{array}{l}\text { Fear of English } \\
\text { Learners }\end{array}$ & $\begin{array}{l}\text { I fear teaching English Learners, I would be } \\
\text { uncomfortable }\end{array}$ & -0.282 \\
\hline C59 & Bilingual Programs & $\begin{array}{l}\text { Bilingual or language programs are not necessary } \\
\text { and divert resources that would be better spent } \\
\text { elsewhere, such as gifted programs }\end{array}$ & -0.204 \\
\hline $\mathrm{C} 01$ & $\begin{array}{l}\text { Personality \& } \\
\text { Behavior }\end{array}$ & $\begin{array}{l}\text { English Learners are lazy and don't care about } \\
\text { their education }\end{array}$ & -0.123 \\
\hline C64 & $\begin{array}{l}\text { Fear of English } \\
\text { Learners }\end{array}$ & $\begin{array}{l}\text { English Learners are aggressive; I would worry } \\
\text { for my safety in teaching in a school with a lot of } \\
\text { English Learners }\end{array}$ & -0.104 \\
\hline C57 & $\begin{array}{l}\text { Language Learning } \\
\text { Process } \\
\end{array}$ & $\begin{array}{l}\text { English Learners social language skills occur } \\
\text { before academic language skills }\end{array}$ & -0.092 \\
\hline $\mathrm{C} 06$ & Intelligence & $\begin{array}{l}\text { English Learners have little knowledge to build } \\
\text { upon the classroom }\end{array}$ & -0.032 \\
\hline $\mathrm{C} 17$ & $\begin{array}{l}\text { Segregation \& Lack of } \\
\text { Support }\end{array}$ & $\begin{array}{l}\text { English Learners tend to go to the worst schools, } \\
\text { and the worst schools have the most English } \\
\text { Learners }\end{array}$ & 0.004 \\
\hline C54 & $\begin{array}{l}\text { Language Learning } \\
\text { Process } \\
\end{array}$ & $\begin{array}{l}\text { Relying on their native language is a barrier to } \\
\text { learning English }\end{array}$ & 0.005 \\
\hline $\mathrm{C} 24$ & $\begin{array}{l}\text { Achievement \& } \\
\text { Expectations }\end{array}$ & $\begin{array}{l}\text { English Learners are so far behind they will never } \\
\text { catch up }\end{array}$ & 0.016 \\
\hline $\mathrm{C} 04$ & Intelligence & $\begin{array}{l}\text { If English Learners would be more intelligent } \\
\text { they would learn English more quickly }\end{array}$ & 0.018 \\
\hline $\mathrm{C} 05$ & Intelligence & $\begin{array}{l}\text { English Learners have difficulties because they } \\
\text { are not very intelligent }\end{array}$ & 0.040 \\
\hline
\end{tabular}




\begin{tabular}{|c|c|c|c|}
\hline C79 & $\begin{array}{l}\text { Origin of English } \\
\text { Learners }\end{array}$ & $\begin{array}{l}\text { Majority of English Learners speak Spanish and } \\
\text { come from Mexico }\end{array}$ & 0.049 \\
\hline $\mathrm{C} 80$ & $\begin{array}{l}\text { Origin of English } \\
\text { Learners }\end{array}$ & $\begin{array}{l}\text { English Learners from Spanish-speaking } \\
\text { countries tend to be more difficult to work with } \\
\text { than students from European countries }\end{array}$ & 0.085 \\
\hline C69 & $\begin{array}{c}\text { Language \& } \\
\text { Cultural Collisions }\end{array}$ & $\begin{array}{l}\text { I prefer to teach students from similar } \\
\text { backgrounds as me. }\end{array}$ & 0.098 \\
\hline $\mathrm{C} 18$ & Assimilation & English Learners are poor & 0.100 \\
\hline $\mathrm{C} 44$ & Language Skills & English Learners have weaker language skills & 0.101 \\
\hline $\mathrm{C} 22$ & At-Risk & $\begin{array}{l}\text { English Learners are at a higher risk for } \\
\text { behavioral and/or learning difficulties }\end{array}$ & 0.109 \\
\hline C60 & White-Savior & $\begin{array}{l}\text { English Learners will not succeed without a } \\
\text { native English-speaking role model }\end{array}$ & 0.118 \\
\hline $\mathrm{C} 08$ & Intelligence & $\begin{array}{l}\text { English Learners with an accent are less } \\
\text { intelligent }\end{array}$ & 0.125 \\
\hline C19 & Assimilation & English Learners come from low income families & 0.129 \\
\hline $\mathrm{C} 02$ & $\begin{array}{l}\text { Personality \& } \\
\text { Behavior }\end{array}$ & English Learners are members of a gang & 0.130 \\
\hline $\mathrm{C} 43$ & Language Skills & English Learners can't speak standard English & 0.130 \\
\hline C55 & $\begin{array}{l}\text { Language Learning } \\
\text { Process }\end{array}$ & $\begin{array}{l}\text { English Learners second language acquisition } \\
\text { process involves accessing their native language }\end{array}$ & 0.134 \\
\hline C52 & Inclusion & $\begin{array}{l}\text { English Learners' inclusion in general } \\
\text { education/mainstream classroom can be } \\
\text { beneficial for themselves and others }\end{array}$ & 0.135 \\
\hline $\mathrm{C} 81$ & $\begin{array}{l}\text { Origin of English } \\
\text { Learners }\end{array}$ & All English Learners are students of color & 0.142 \\
\hline $\mathrm{C} 83$ & $\begin{array}{l}\text { Experience teaching } \\
\text { ELs }\end{array}$ & $\begin{array}{l}\text { Teaching English Learners is a challenging and } \\
\text { rewarding experience }\end{array}$ & 0.152 \\
\hline C50 & Inclusion & $\begin{array}{l}\text { English Learners should not be placed in a regular } \\
\text { classroom until they are fluent in English }\end{array}$ & 0.154 \\
\hline $\mathrm{C} 21$ & Assimilation & $\begin{array}{l}\text { The more English Learners insist in maintaining } \\
\text { their culture and language the slower they will be } \\
\text { to assimilate and learn English and/or the worst } \\
\text { off they will be }\end{array}$ & 0.159 \\
\hline $\mathrm{C} 13$ & Immigration & $\begin{array}{l}\text { English Learners are typically illegal immigrants } \\
\text { and drain tax payer resources }\end{array}$ & 0.166 \\
\hline $\mathrm{C} 07$ & Intelligence & $\begin{array}{l}\text { English Learners have street smarts but not } \\
\text { school smarts }\end{array}$ & 0.173 \\
\hline C77 & $\begin{array}{c}\text { Training \& Culturally } \\
\text { Responsive }\end{array}$ & $\begin{array}{l}\text { I know specific strategies for designing } \\
\text { instruction that is responsive to students' cultural } \\
\text { differences }\end{array}$ & 0.177 \\
\hline $\mathrm{C} 84$ & $\begin{array}{l}\text { Experience teaching } \\
\text { ELs }\end{array}$ & $\begin{array}{l}\text { Teaching English Learners has made me a better } \\
\text { teacher }\end{array}$ & 0.184 \\
\hline
\end{tabular}




\begin{tabular}{|c|c|c|c|}
\hline $\mathrm{C} 32$ & Culture Influence & $\begin{array}{l}\text { English Learner students are not exposed to } \\
\text { cultural enriching experiences by their families }\end{array}$ & 0.190 \\
\hline $\mathrm{C} 85$ & $\begin{array}{l}\text { Experience teaching } \\
\text { ELs }\end{array}$ & $\begin{array}{l}\text { Teaching English Learners is an empathy } \\
\text { building experience }\end{array}$ & 0.190 \\
\hline C51 & Inclusion & $\begin{array}{l}\text { Having English Learner students in our } \\
\text { classrooms is a gift }\end{array}$ & 0.232 \\
\hline $\mathrm{C} 45$ & Language skills & $\begin{array}{l}\text { English Learners need to be immersed in English- } \\
\text { only }\end{array}$ & 0.235 \\
\hline $\mathrm{C} 40$ & Parents Influence & $\begin{array}{l}\text { English Learners struggle because their parents } \\
\text { do not care about their education }\end{array}$ & 0.251 \\
\hline $\mathrm{C} 38$ & Parents Influence & $\begin{array}{l}\text { English Learners parents do not care about } \\
\text { education and don't want their children learning } \\
\text { English }\end{array}$ & 0.251 \\
\hline $\mathrm{C} 16$ & $\begin{array}{c}\text { Segregation \& Lack of } \\
\text { Support }\end{array}$ & $\begin{array}{l}\text { English Learners often do not receive the support } \\
\text { they need from home }\end{array}$ & 0.252 \\
\hline C58 & $\begin{array}{l}\text { Language Learning } \\
\text { Process }\end{array}$ & $\begin{array}{l}\text { English Learners who learn to read and write in } \\
\text { their native language first acquire stronger } \\
\text { English language and literacy skills later. }\end{array}$ & 0.253 \\
\hline $\mathrm{C} 14$ & Immigration & $\begin{array}{l}\text { English Learners' families do not want to learn } \\
\text { English }\end{array}$ & 0.282 \\
\hline $\mathrm{C} 42$ & Language Skills & $\begin{array}{l}\text { English Learners can't speak their native language } \\
\text { correctly }\end{array}$ & 0.282 \\
\hline $\mathrm{C} 41$ & Home Life & English Learners have unhappy home lives & 0.301 \\
\hline $\mathrm{C} 27$ & $\begin{array}{l}\text { Achievement \& } \\
\text { Expectations }\end{array}$ & $\begin{array}{l}\text { English Learners will be academically successful, } \\
\text { and are just as capable of going to college as } \\
\text { native English speakers }\end{array}$ & 0.361 \\
\hline C61 & White-Savior & $\begin{array}{l}\text { English Learners need to be helped become } \\
\text { Americanized }\end{array}$ & 0.415 \\
\hline $\mathrm{C} 10$ & Intelligence & $\begin{array}{l}\text { English Learners have the capacity to learn } \\
\text { despite their language skills }\end{array}$ & 0.423 \\
\hline $\mathrm{C} 36$ & $\begin{array}{c}\text { Cultural } \\
\text { Capital/Deprived } \\
\end{array}$ & $\begin{array}{l}\text { English Learner students have many strengths } \\
\text { that they bring with them into the classroom }\end{array}$ & 0.466 \\
\hline $\mathrm{C} 30$ & Color-Blind & I desire to teach English Learner student & 0.525 \\
\hline $\mathrm{C} 46$ & Language skills & $\begin{array}{l}\text { Keeping and strengthening native language skills } \\
\text { (L1) of English Learners helps their ability to } \\
\text { learn English }\end{array}$ & 0.577 \\
\hline $\mathrm{C} 49$ & Language Skills & $\begin{array}{l}\text { Bilingual students have stronger higher-level } \\
\text { thinking skills than students who only speak } \\
\text { English }\end{array}$ & 0.598 \\
\hline C09 & Intelligence & $\begin{array}{l}\text { English Learners language skills are not } \\
\text { indicative of their intelligence }\end{array}$ & 0.601 \\
\hline $\mathrm{C} 86$ & $\begin{array}{l}\text { Experience teaching } \\
\text { ELs }\end{array}$ & $\begin{array}{l}\text { I look forward to having English Learner students } \\
\text { in my classroom }\end{array}$ & 0.604 \\
\hline
\end{tabular}




\begin{tabular}{|c|c|c|c|}
\hline C56 & $\begin{array}{l}\text { Language Learning } \\
\text { Process }\end{array}$ & $\begin{array}{l}\text { Spanish language skills are helpful in learning } \\
\text { English language as a second language }\end{array}$ & 0.615 \\
\hline $\mathrm{C} 48$ & Language Skills & Bilingualism benefits English Learners & 0.627 \\
\hline $\mathrm{C} 03$ & $\begin{array}{c}\text { Personality \& } \\
\text { Behavior }\end{array}$ & $\begin{array}{l}\text { English Learners care about their education, thus } \\
\text { they are well-behaved }\end{array}$ & 0.644 \\
\hline $\mathrm{C} 88$ & $\begin{array}{l}\text { Experience teaching } \\
\text { English Learners }\end{array}$ & $\begin{array}{l}\text { I have had the opportunity to develop close } \\
\text { relationships with English Learner students } \\
\text { and/or their families }\end{array}$ & 0.698 \\
\hline C76 & $\begin{array}{l}\text { Training \& Culturally } \\
\text { Responsive }\end{array}$ & $\begin{array}{l}\text { I know specific strategies for designing } \\
\text { instruction that is responsive to students' language } \\
\text { needs }\end{array}$ & 0.704 \\
\hline $\mathrm{C} 87$ & $\begin{array}{l}\text { Experience teaching } \\
\text { ELs }\end{array}$ & $\begin{array}{l}\text { I have worked with a lot of English Learner } \\
\text { students }\end{array}$ & 0.706 \\
\hline $\mathrm{C} 20$ & Assimilation & $\begin{array}{l}\text { The faster English Learners students assimilate } \\
\text { the better of they will be }\end{array}$ & 0.750 \\
\hline C66 & $\begin{array}{l}\text { Fear of English } \\
\text { Learners }\end{array}$ & I feel prepared in teaching English Learners & 0.753 \\
\hline $\mathrm{C} 11$ & $\begin{array}{l}\text { Relate to English } \\
\text { Learners }\end{array}$ & $\begin{array}{l}\text { I feel more comfortable working with English } \\
\text { Learners than other minority students }\end{array}$ & 0.767 \\
\hline $\mathrm{C} 33$ & Culture Influence & $\begin{array}{l}\text { English Learners knowledge is due to their } \\
\text { enriching cultural experiences }\end{array}$ & 0.862 \\
\hline $\mathrm{C} 26$ & $\begin{array}{l}\text { Achievement \& } \\
\text { Expectations }\end{array}$ & $\begin{array}{l}\text { English Learner students are more motivated to } \\
\text { succeed than many of their native English- } \\
\text { speaking peers }\end{array}$ & 0.887 \\
\hline C31 & Culture Influence & $\begin{array}{l}\text { English Learner students' families expose them to } \\
\text { a wide range of cultural experiences }\end{array}$ & 0.935 \\
\hline $\mathrm{C} 47$ & Language Skills & $\begin{array}{l}\text { All students in the United States should learn to } \\
\text { speak more than one language }\end{array}$ & 0.950 \\
\hline $\mathrm{C} 12$ & $\begin{array}{l}\text { Relate to English } \\
\text { Learners }\end{array}$ & $\begin{array}{l}\text { I can relate to the struggles English Learners } \\
\text { encounter and understand their needs }\end{array}$ & 1.031 \\
\hline C39 & Parents Influence & $\begin{array}{l}\text { English Learner's parents want their children to } \\
\text { learn English and/or be bilingual }\end{array}$ & 1.267 \\
\hline
\end{tabular}


APPENDIX J: INDSCAL SUBGROUP CONFIGURATION - DIMENSION 1 RANKINGS

\begin{tabular}{|c|c|c|c|}
\hline Card \# & Category & Statement Text & Dim 1 \\
\hline $\mathrm{C} 92$ & $\begin{array}{l}\text { Differentiated } \\
\text { Instruction }\end{array}$ & $\begin{array}{l}\text { It is the responsibility of teachers to be aware of the } \\
\text { language diversity of learners in their classrooms and to } \\
\text { structure their lessons, as well as adjust their teaching } \\
\text { styles, to meet these students' needs }\end{array}$ & -1.454 \\
\hline $\mathrm{C} 35$ & Culture Influence & $\begin{array}{l}\text { It is important for mainstream teacher to understand and } \\
\text { know how English Learner parents' view schools and } \\
\text { learning }\end{array}$ & -1.446 \\
\hline $\mathrm{C} 83$ & $\begin{array}{l}\text { Experience } \\
\text { teaching ELs }\end{array}$ & $\begin{array}{l}\text { Teaching English Learners is a challenging and } \\
\text { rewarding experience }\end{array}$ & -1.439 \\
\hline $\mathrm{C} 72$ & $\begin{array}{l}\text { Culturally } \\
\text { Responsive }\end{array}$ & $\begin{array}{l}\text { Teachers need special training in working with English } \\
\text { Learners }\end{array}$ & -1.381 \\
\hline $\mathrm{C} 89$ & $\begin{array}{l}\text { Educational } \\
\text { Challenges }\end{array}$ & $\begin{array}{l}\text { Teaching language minority students successfully } \\
\text { means above all challenging one's attitudes toward the } \\
\text { students, their languages and cultures, and their } \\
\text { communities }\end{array}$ & -1.346 \\
\hline C91 & $\begin{array}{l}\text { Differentiated } \\
\text { Instruction }\end{array}$ & $\begin{array}{l}\text { Teachers should differentiate instruction and assessment } \\
\text { for English Learners }\end{array}$ & -1.334 \\
\hline $\mathrm{C} 84$ & $\begin{array}{l}\text { Experience } \\
\text { teaching ELs }\end{array}$ & Teaching English Learners has made me a better teacher & -1.324 \\
\hline $\mathrm{C} 86$ & $\begin{array}{l}\text { Experience } \\
\text { teaching ELs }\end{array}$ & $\begin{array}{l}\text { I look forward to having English Learner students in my } \\
\text { classroom }\end{array}$ & -1.317 \\
\hline $\mathrm{C} 30$ & Color-Blind & I desire to teach English Learner student & -1.307 \\
\hline $\mathrm{C} 28$ & $\begin{array}{l}\text { Achievement \& } \\
\text { Expectations }\end{array}$ & $\begin{array}{l}\text { Mainstream teachers are responsible for English } \\
\text { Learners' achievement }\end{array}$ & -1.301 \\
\hline $\mathrm{C} 75$ & $\begin{array}{l}\text { Training \& } \\
\text { Culturally } \\
\text { Responsive }\end{array}$ & $\begin{array}{l}\text { English Learners need teachers that can create culturally } \\
\text { inclusive learning materials }\end{array}$ & -1.291 \\
\hline C51 & Inclusion & $\begin{array}{l}\text { Having English Learner students in our classrooms is a } \\
\text { gift }\end{array}$ & -1.277 \\
\hline C53 & Inclusion & $\begin{array}{l}\text { It is important for English Learner students to feel } \\
\text { comfortable and receive teacher assistance when } \\
\text { transitioning into a general education classroom }\end{array}$ & -1.234 \\
\hline $\mathrm{C} 77$ & $\begin{array}{l}\text { Training \& } \\
\text { Culturally } \\
\text { Responsive }\end{array}$ & $\begin{array}{l}\text { I know specific strategies for designing instruction that } \\
\text { is responsive to students' cultural differences }\end{array}$ & -1.216 \\
\hline $\mathrm{C} 37$ & $\begin{array}{c}\text { Cultural } \\
\text { Capital/Deprived }\end{array}$ & $\begin{array}{l}\text { English Learner students will succeed in school when } \\
\text { mainstream teachers affirm their cultural identities }\end{array}$ & -1.213 \\
\hline $\mathrm{C} 76$ & $\begin{array}{l}\text { Training \& } \\
\text { Culturally } \\
\text { Responsive }\end{array}$ & $\begin{array}{l}\text { I know specific strategies for designing instruction that } \\
\text { is responsive to students' language needs }\end{array}$ & -1.162 \\
\hline C63 & White-Savior & $\begin{array}{l}\text { English Learners need teachers that provide a support } \\
\text { system and guides them in schools }\end{array}$ & -1.149 \\
\hline
\end{tabular}




\begin{tabular}{|c|c|c|c|}
\hline $\mathrm{C} 52$ & Inclusion & $\begin{array}{l}\text { English Learners' inclusion in general } \\
\text { education/mainstream classroom can be beneficial for } \\
\text { themselves and others }\end{array}$ & -1.106 \\
\hline $\mathrm{C} 88$ & $\begin{array}{l}\text { Experience } \\
\text { teaching ELs }\end{array}$ & $\begin{array}{l}\text { I have had the opportunity to develop close relationships } \\
\text { with English Learner students and/or their families }\end{array}$ & -1.041 \\
\hline $\mathrm{C} 36$ & $\begin{array}{c}\text { Cultural } \\
\text { Capital/Deprived }\end{array}$ & $\begin{array}{l}\text { English Learner students have many strengths that they } \\
\text { bring with them into the classroom }\end{array}$ & -1.038 \\
\hline $\mathrm{C} 87$ & $\begin{array}{l}\text { Experience } \\
\text { teaching ELs }\end{array}$ & I have worked with a lot of English Learner students & -1.032 \\
\hline $\mathrm{C} 27$ & $\begin{array}{l}\text { Achievement \& } \\
\text { Expectations }\end{array}$ & $\begin{array}{l}\text { English Learners will be academically successful, and } \\
\text { are just as capable of going to college as native English } \\
\text { speakers }\end{array}$ & -1.019 \\
\hline $\mathrm{C} 10$ & Intelligence & $\begin{array}{l}\text { English Learners have the capacity to learn despite their } \\
\text { language skills }\end{array}$ & -0.995 \\
\hline $\mathrm{C} 85$ & $\begin{array}{l}\text { Experience } \\
\text { teaching ELs }\end{array}$ & $\begin{array}{l}\text { Teaching English Learners is an empathy building } \\
\text { experience }\end{array}$ & -0.978 \\
\hline $\mathrm{C} 48$ & Language Skills & Bilingualism benefits English Learners & -0.952 \\
\hline C93 & $\begin{array}{l}\text { Equitable } \\
\text { Education }\end{array}$ & $\begin{array}{l}\text { English Learner students deserve more support and } \\
\text { caring teachers in schools }\end{array}$ & -0.906 \\
\hline C66 & $\begin{array}{l}\text { Fear of English } \\
\text { Learners }\end{array}$ & I feel prepared in teaching English Learners & -0.899 \\
\hline C56 & $\begin{array}{c}\text { Language } \\
\text { Learning Process } \\
\end{array}$ & $\begin{array}{l}\text { Spanish language skills are helpful in learning English } \\
\text { language as a second language }\end{array}$ & -0.855 \\
\hline C62 & White-Savior & $\begin{array}{l}\text { English Learner students need support from teachers } \\
\text { beyond academics }\end{array}$ & -0.851 \\
\hline C67 & Racism & Teachers' racism impacts English Learners achievement & -0.838 \\
\hline $\mathrm{C} 12$ & $\begin{array}{l}\text { Relate to English } \\
\text { Learners }\end{array}$ & $\begin{array}{l}\text { I can relate to the struggles English Learners encounter } \\
\text { and understand their needs }\end{array}$ & -0.792 \\
\hline $\mathrm{C} 58$ & $\begin{array}{l}\text { Language } \\
\text { Learning Process }\end{array}$ & $\begin{array}{l}\text { English Learners who learn to read and write in their } \\
\text { native language first acquire stronger English language } \\
\text { and literacy skills later. }\end{array}$ & -0.684 \\
\hline $\mathrm{C} 46$ & Language skills & $\begin{array}{l}\text { Keeping and strengthening native language skills (L1) } \\
\text { of English Learners helps their ability to learn English }\end{array}$ & -0.672 \\
\hline $\mathrm{C} 47$ & Language Skills & $\begin{array}{l}\text { All students in the United States should learn to speak } \\
\text { more than one language }\end{array}$ & -0.666 \\
\hline $\mathrm{C} 78$ & Unawareness & Teachers lack awareness about English Learners & -0.601 \\
\hline $\mathrm{C} 11$ & $\begin{array}{l}\text { Relate to English } \\
\text { Learners }\end{array}$ & $\begin{array}{l}\text { I feel more comfortable working with English Learners } \\
\text { than other minority students }\end{array}$ & -0.529 \\
\hline $\mathrm{C} 57$ & $\begin{array}{c}\text { Language } \\
\text { Learning Process } \\
\end{array}$ & $\begin{array}{l}\text { English Learners social language skills occur before } \\
\text { academic language skills }\end{array}$ & -0.489 \\
\hline C09 & Intelligence & $\begin{array}{l}\text { English Learners language skills are not indicative of } \\
\text { their intelligence }\end{array}$ & -0.482 \\
\hline C71 & $\begin{array}{l}\text { Training \& } \\
\text { Culturally } \\
\text { Responsive }\end{array}$ & $\begin{array}{l}\text { Most teachers are not prepared in working with English } \\
\text { Learners }\end{array}$ & -0.470 \\
\hline
\end{tabular}




\begin{tabular}{|c|c|c|c|}
\hline C39 & Parents Influence & $\begin{array}{l}\text { English Learner's parents want their children to learn } \\
\text { English and/or be bilingual }\end{array}$ & -0.441 \\
\hline C55 & $\begin{array}{c}\text { Language } \\
\text { Learning Process } \\
\end{array}$ & $\begin{array}{l}\text { English Learners second language acquisition process } \\
\text { involves accessing their native language }\end{array}$ & -0.440 \\
\hline $\mathrm{C} 31$ & Culture Influence & $\begin{array}{l}\text { English Learner students' families expose them to a } \\
\text { wide range of cultural experiences }\end{array}$ & -0.423 \\
\hline $\mathrm{C} 29$ & $\begin{array}{l}\text { Achievement \& } \\
\text { Expectations }\end{array}$ & $\begin{array}{l}\text { Mainstream teachers are responsible for English } \\
\text { Learners' achievement }\end{array}$ & -0.377 \\
\hline C90 & $\begin{array}{l}\text { Educational } \\
\text { Challenges }\end{array}$ & $\begin{array}{l}\text { The low achievement of English Learner students often } \\
\text { is the result of negative teacher attitudes towards them }\end{array}$ & -0.350 \\
\hline $\mathrm{C} 33$ & Culture Influence & $\begin{array}{l}\text { English Learners knowledge is due to their enriching } \\
\text { cultural experiences }\end{array}$ & -0.317 \\
\hline C49 & Language Skills & $\begin{array}{l}\text { Bilingual students have stronger higher-level thinking } \\
\text { skills than students who only speak English }\end{array}$ & -0.305 \\
\hline $\mathrm{C} 03$ & $\begin{array}{c}\text { Personality \& } \\
\text { Behavior }\end{array}$ & $\begin{array}{l}\text { English Learners care about their education, thus they } \\
\text { are well-behaved }\end{array}$ & -0.231 \\
\hline $\mathrm{C} 15$ & $\begin{array}{c}\text { Segregation \& } \\
\text { Lack of Support }\end{array}$ & English Learners often do not receive support in schools & -0.136 \\
\hline $\mathrm{C} 26$ & $\begin{array}{l}\text { Achievement \& } \\
\text { Expectations }\end{array}$ & $\begin{array}{l}\text { English Learner students are more motivated to succeed } \\
\text { than many of their native English-speaking peers }\end{array}$ & -0.093 \\
\hline $\mathrm{C} 25$ & $\begin{array}{l}\text { Achievement \& } \\
\text { Expectations }\end{array}$ & Teachers have low expectations from English Learners & 0.066 \\
\hline $\mathrm{C} 70$ & $\begin{array}{c}\text { Language \& } \\
\text { Cultural } \\
\text { Collisions }\end{array}$ & $\begin{array}{l}\text { Cultural and linguistic differences between students and } \\
\text { teachers inhibits effective education of English Learners }\end{array}$ & 0.375 \\
\hline C69 & $\begin{array}{c}\text { Language \& } \\
\text { Cultural } \\
\text { Collisions }\end{array}$ & $\begin{array}{l}\text { I prefer to teach students from similar backgrounds as } \\
\text { me. }\end{array}$ & 0.436 \\
\hline $\mathrm{C} 73$ & $\begin{array}{l}\text { Training \& } \\
\text { Culturally } \\
\text { Responsive }\end{array}$ & Most teachers don't want to work with English Learners & 0.533 \\
\hline C65 & $\begin{array}{l}\text { Fear of English } \\
\text { Learners }\end{array}$ & $\begin{array}{l}\text { I fear teaching English Learners, I would be } \\
\text { uncomfortable }\end{array}$ & 0.553 \\
\hline C82 & $\begin{array}{l}\text { Experience } \\
\text { teaching ELs }\end{array}$ & $\begin{array}{l}\text { Teaching English Learners is a difficult and scary } \\
\text { experience }\end{array}$ & 0.700 \\
\hline $\mathrm{C} 23$ & $\begin{array}{l}\text { Achievement \& } \\
\text { Expectations }\end{array}$ & $\begin{array}{l}\text { English Learners' teachers should not be held } \\
\text { accountable for their achievement }\end{array}$ & 0.722 \\
\hline C74 & $\begin{array}{c}\text { Training \& } \\
\text { Culturally } \\
\text { Responsive }\end{array}$ & $\begin{array}{l}\text { Training all teachers to work with English Learners is a } \\
\text { waste of resources }\end{array}$ & 0.777 \\
\hline $\mathrm{C} 20$ & Assimilation & $\begin{array}{l}\text { The faster English Learners students assimilate the } \\
\text { better of they will be }\end{array}$ & 0.804 \\
\hline C68 & $\begin{array}{c}\text { Language \& } \\
\text { Cultural } \\
\text { Collisions }\end{array}$ & $\begin{array}{l}\text { Only teachers of color can be effective teaching English } \\
\text { Learners or relate to English Learner students }\end{array}$ & 0.896 \\
\hline
\end{tabular}




\begin{tabular}{|c|c|c|c|}
\hline C79 & $\begin{array}{l}\text { Origin of English } \\
\text { Learners }\end{array}$ & $\begin{array}{l}\text { Majority of English Learners speak Spanish and come } \\
\text { from Mexico }\end{array}$ & 0.970 \\
\hline $\mathrm{C} 16$ & $\begin{array}{l}\text { Segregation \& } \\
\text { Lack of Support }\end{array}$ & $\begin{array}{l}\text { English Learners often do not receive the support they } \\
\text { need from home }\end{array}$ & 0.971 \\
\hline $\mathrm{C} 60$ & White-Savior & $\begin{array}{l}\text { English Learners will not succeed without a native } \\
\text { English-speaking role model }\end{array}$ & 1.023 \\
\hline C59 & $\begin{array}{l}\text { Bilingual } \\
\text { Programs }\end{array}$ & $\begin{array}{l}\text { Bilingual or language programs are not necessary and } \\
\text { divert resources that would be better spent elsewhere, } \\
\text { such as gifted programs }\end{array}$ & 1.035 \\
\hline $\mathrm{C} 50$ & Inclusion & $\begin{array}{l}\text { English Learners should not be placed in a regular } \\
\text { classroom until they are fluent in English }\end{array}$ & 1.064 \\
\hline $\mathrm{C} 22$ & At-Risk & $\begin{array}{l}\text { English Learners are at a higher risk for behavioral } \\
\text { and/or learning difficulties }\end{array}$ & 1.073 \\
\hline $\mathrm{C} 02$ & $\begin{array}{l}\text { Personality \& } \\
\text { Behavior }\end{array}$ & English Learners are members of a gang & 1.117 \\
\hline C81 & $\begin{array}{l}\text { Origin of English } \\
\text { Learners }\end{array}$ & All English Learners are students of color & 1.120 \\
\hline $\mathrm{C} 06$ & Intelligence & $\begin{array}{l}\text { English Learners have little knowledge to build upon the } \\
\text { classroom }\end{array}$ & 1.120 \\
\hline $\mathrm{C} 04$ & Intelligence & $\begin{array}{l}\text { If English Learners would be more intelligent they } \\
\text { would learn English more quickly }\end{array}$ & 1.128 \\
\hline $\mathrm{C} 80$ & $\begin{array}{l}\text { Origin of English } \\
\text { Learners }\end{array}$ & $\begin{array}{l}\text { English Learners from Spanish-speaking countries tend } \\
\text { to be more difficult to work with than students from } \\
\text { European countries }\end{array}$ & 1.129 \\
\hline $\mathrm{C} 38$ & Parents Influence & $\begin{array}{l}\text { English Learners parents do not care about education } \\
\text { and don't want their children learning English }\end{array}$ & 1.130 \\
\hline $\mathrm{C} 01$ & $\begin{array}{l}\text { Personality \& } \\
\text { Behavior }\end{array}$ & $\begin{array}{l}\text { English Learners are lazy and don't care about their } \\
\text { education }\end{array}$ & 1.130 \\
\hline $\mathrm{C} 05$ & Intelligence & $\begin{array}{l}\text { English Learners have difficulties because they are not } \\
\text { very intelligent }\end{array}$ & 1.131 \\
\hline C64 & $\begin{array}{l}\text { Fear of English } \\
\text { Learners }\end{array}$ & $\begin{array}{l}\text { English Learners are aggressive; I would worry for my } \\
\text { safety in teaching in a school with a lot of English } \\
\text { Learners }\end{array}$ & 1.131 \\
\hline C54 & $\begin{array}{c}\text { Language } \\
\text { Learning Process }\end{array}$ & $\begin{array}{l}\text { Relying on their native language is a barrier to learning } \\
\text { English }\end{array}$ & 1.139 \\
\hline $\mathrm{C} 24$ & $\begin{array}{l}\text { Achievement \& } \\
\text { Expectations }\end{array}$ & $\begin{array}{l}\text { English Learners are so far behind they will never catch } \\
\text { up }\end{array}$ & 1.145 \\
\hline $\mathrm{C} 45$ & Language skills & English Learners need to be immersed in English-only & 1.146 \\
\hline $\mathrm{C} 21$ & Assimilation & $\begin{array}{l}\text { The more English Learners insist in maintaining their } \\
\text { culture and language the slower they will be to } \\
\text { assimilate and learn English and/or the worst off they } \\
\text { will be }\end{array}$ & 1.152 \\
\hline $\mathrm{C} 17$ & $\begin{array}{l}\text { Segregation \& } \\
\text { Lack of Support }\end{array}$ & $\begin{array}{l}\text { English Learners tend to go to the worst schools, and the } \\
\text { worst schools have the most English Learners }\end{array}$ & 1.153 \\
\hline $\mathrm{C} 08$ & Intelligence & English Learners with an accent are less intelligent & 1.154 \\
\hline
\end{tabular}




\begin{tabular}{lclc}
\hline C40 & Parents Influence & $\begin{array}{l}\text { English Learners struggle because their parents do not } \\
\text { care about their education }\end{array}$ & 1.162 \\
\hline C61 & White-Savior & $\begin{array}{l}\text { English Learners need to be helped become } \\
\text { Americanized }\end{array}$ & 1.167 \\
\hline C13 & Immigration & $\begin{array}{l}\text { English Learners are typically illegal immigrants and } \\
\text { drain tax payer resources }\end{array}$ & 1.168 \\
\hline C44 & Language Skills & English Learners have weaker language skills & 1.168 \\
\hline C07 & Intelligence & $\begin{array}{l}\text { English Learners have street smarts but not school } \\
\text { smarts }\end{array}$ & 1.171 \\
\hline C14 & Immigration & English Learners' families do not want to learn English & 1.171 \\
\hline C43 & Language Skills & English Learners can't speak standard English & 1.173 \\
\hline C18 & Assimilation & English Learners are poor & 1.189 \\
\hline C42 & Language Skills & $\begin{array}{l}\text { English Learners can't speak their native language } \\
\text { correctly }\end{array}$ & 1.191 \\
\hline C19 & Assimilation & English Learners come from low income families & 1.193 \\
\hline C41 & Home Life & English Learners have unhappy home lives & 1.199 \\
\hline C32 & Culture Influence & $\begin{array}{l}\text { English Learner students are not exposed to cultural } \\
\text { enriching experiences by their families }\end{array}$ & 1.223 \\
\hline
\end{tabular}


APPENDIX K: INDSCAL SUBGROUP CONFIGURATION - DIMENSION 2 RANKINGS

\begin{tabular}{|c|c|c|c|}
\hline Card \# & Category & Statement Text & Dim. 2 \\
\hline $\mathrm{C} 26$ & $\begin{array}{l}\text { Achievement \& } \\
\text { Expectations }\end{array}$ & $\begin{array}{l}\text { English Learner students are more motivated to } \\
\text { succeed than many of their native English-speaking } \\
\text { peers }\end{array}$ & -2.005 \\
\hline C55 & $\begin{array}{l}\text { Language Learning } \\
\text { Process }\end{array}$ & $\begin{array}{l}\text { English Learners second language acquisition process } \\
\text { involves accessing their native language }\end{array}$ & -1.996 \\
\hline $\mathrm{C} 03$ & $\begin{array}{l}\text { Personality \& } \\
\text { Behavior }\end{array}$ & $\begin{array}{l}\text { English Learners care about their education, thus they } \\
\text { are well-behaved }\end{array}$ & -1.954 \\
\hline C58 & $\begin{array}{l}\text { Language Learning } \\
\text { Process }\end{array}$ & $\begin{array}{l}\text { English Learners who learn to read and write in their } \\
\text { native language first acquire stronger English language } \\
\text { and literacy skills later. }\end{array}$ & -1.938 \\
\hline C57 & $\begin{array}{l}\text { Language Learning } \\
\text { Process }\end{array}$ & $\begin{array}{l}\text { English Learners social language skills occur before } \\
\text { academic language skills }\end{array}$ & -1.874 \\
\hline C49 & Language Skills & $\begin{array}{l}\text { Bilingual students have stronger higher-level thinking } \\
\text { skills than students who only speak English }\end{array}$ & -1.840 \\
\hline $\mathrm{C} 46$ & Language skills & $\begin{array}{l}\text { Keeping and strengthening native language skills (L1) } \\
\text { of English Learners helps their ability to learn English }\end{array}$ & -1.739 \\
\hline $\mathrm{C} 33$ & Culture Influence & $\begin{array}{l}\text { English Learners knowledge is due to their enriching } \\
\text { cultural experiences }\end{array}$ & -1.722 \\
\hline C31 & Culture Influence & $\begin{array}{l}\text { English Learner students' families expose them to a } \\
\text { wide range of cultural experiences }\end{array}$ & -1.716 \\
\hline C56 & $\begin{array}{l}\text { Language Learning } \\
\text { Process }\end{array}$ & $\begin{array}{l}\text { Spanish language skills are helpful in learning English } \\
\text { language as a second language }\end{array}$ & -1.632 \\
\hline C39 & Parents Influence & $\begin{array}{l}\text { English Learner's parents want their children to learn } \\
\text { English and/or be bilingual }\end{array}$ & -1.578 \\
\hline $\mathrm{C} 48$ & Language Skills & Bilingualism benefits English Learners & -1.381 \\
\hline $\mathrm{C} 09$ & Intelligence & $\begin{array}{l}\text { English Learners language skills are not indicative of } \\
\text { their intelligence }\end{array}$ & -1.368 \\
\hline $\mathrm{C} 27$ & $\begin{array}{l}\text { Achievement \& } \\
\text { Expectations }\end{array}$ & $\begin{array}{l}\text { English Learners will be academically successful, and } \\
\text { are just as capable of going to college as native English } \\
\text { speakers }\end{array}$ & -1.359 \\
\hline $\mathrm{C} 10$ & Intelligence & $\begin{array}{l}\text { English Learners have the capacity to learn despite } \\
\text { their language skills }\end{array}$ & -1.354 \\
\hline C62 & White-Savior & $\begin{array}{l}\text { English Learner students need support from teachers } \\
\text { beyond academics }\end{array}$ & -1.255 \\
\hline C36 & $\begin{array}{c}\text { Cultural } \\
\text { Capital/Deprived }\end{array}$ & $\begin{array}{l}\text { English Learner students have many strengths that they } \\
\text { bring with them into the classroom }\end{array}$ & -1.208 \\
\hline C52 & Inclusion & $\begin{array}{l}\text { English Learners' inclusion in general } \\
\text { education/mainstream classroom can be beneficial for } \\
\text { themselves and others }\end{array}$ & -1.146 \\
\hline C63 & White-Savior & $\begin{array}{l}\text { English Learners need teachers that provide a support } \\
\text { system and guides them in schools }\end{array}$ & -1.137 \\
\hline
\end{tabular}




\begin{tabular}{|c|c|c|c|}
\hline $\mathrm{C} 47$ & Language Skills & $\begin{array}{l}\text { All students in the United States should learn to speak } \\
\text { more than one language }\end{array}$ & -1.102 \\
\hline $\mathrm{C} 53$ & Inclusion & $\begin{array}{l}\text { It is important for English Learner students to feel } \\
\text { comfortable and receive teacher assistance when } \\
\text { transitioning into a general education classroom }\end{array}$ & -1.004 \\
\hline C93 & Equitable Education & $\begin{array}{l}\text { English Learner students deserve more support and } \\
\text { caring teachers in schools }\end{array}$ & -0.935 \\
\hline $\mathrm{C} 37$ & $\begin{array}{c}\text { Cultural } \\
\text { Capital/Deprived }\end{array}$ & $\begin{array}{l}\text { English Learner students will succeed in school when } \\
\text { mainstream teachers affirm their cultural identities }\end{array}$ & -0.903 \\
\hline C75 & $\begin{array}{l}\text { Training \& Culturally } \\
\text { Responsive }\end{array}$ & $\begin{array}{l}\text { English Learners need teachers that can create } \\
\text { culturally inclusive learning materials }\end{array}$ & -0.790 \\
\hline $\mathrm{C} 15$ & $\begin{array}{c}\text { Segregation \& Lack of } \\
\text { Support }\end{array}$ & $\begin{array}{l}\text { English Learners often do not receive support in } \\
\text { schools }\end{array}$ & -0.746 \\
\hline $\mathrm{C} 16$ & $\begin{array}{l}\text { Segregation \& Lack of } \\
\text { Support }\end{array}$ & $\begin{array}{l}\text { f English Learners often do not receive the support they } \\
\text { need from home }\end{array}$ & -0.491 \\
\hline C90 & $\begin{array}{l}\text { Educational } \\
\text { Challenges }\end{array}$ & $\begin{array}{l}\text { The low achievement of English Learner students often } \\
\text { is the result of negative teacher attitudes towards them }\end{array}$ & -0.430 \\
\hline $\mathrm{C} 20$ & Assimilation & $\begin{array}{l}\text { The faster English Learners students assimilate the } \\
\text { better of they will be }\end{array}$ & -0.188 \\
\hline C79 & $\begin{array}{l}\text { Origin of English } \\
\text { Learners }\end{array}$ & $\begin{array}{l}\text { Majority of English Learners speak Spanish and come } \\
\text { from Mexico }\end{array}$ & -0.187 \\
\hline $\mathrm{C} 70$ & $\begin{array}{l}\text { Language \& Cultural } \\
\text { Collisions }\end{array}$ & $\begin{array}{l}\text { Cultural and linguistic differences between students } \\
\text { and teachers inhibits effective education of English } \\
\text { Learners }\end{array}$ & -0.153 \\
\hline $\mathrm{C} 85$ & $\begin{array}{l}\text { Experience teaching } \\
\text { ELs }\end{array}$ & $\begin{array}{l}\text { Teaching English Learners is an empathy building } \\
\text { experience }\end{array}$ & -0.144 \\
\hline $\mathrm{C} 22$ & At-Risk & $\begin{array}{l}\text { English Learners are at a higher risk for behavioral } \\
\text { and/or learning difficulties }\end{array}$ & -0.143 \\
\hline C92 & $\begin{array}{l}\text { Differentiated } \\
\text { Instruction }\end{array}$ & $\begin{array}{l}\text { It is the responsibility of teachers to be aware of the } \\
\text { language diversity of learners in their classrooms and } \\
\text { to structure their lessons, as well as adjust their } \\
\text { teaching styles, to meet these students' needs }\end{array}$ & -0.096 \\
\hline $\mathrm{C} 35$ & Culture Influence & $\begin{array}{l}\text { It is important for mainstream teacher to understand } \\
\text { and know how English Learner parents' view schools } \\
\text { and learning }\end{array}$ & -0.026 \\
\hline C72 & Culturally Responsive & $\begin{array}{l}\text { Teachers need special training in working with English } \\
\text { Learners }\end{array}$ & -0.010 \\
\hline $\mathrm{C} 32$ & Culture Influence & $\begin{array}{l}\text { English Learner students are not exposed to cultural } \\
\text { enriching experiences by their families }\end{array}$ & 0.096 \\
\hline C14 & Immigration & English Learners' families do not want to learn English & 0.156 \\
\hline $\mathrm{C} 41$ & Home Life & English Learners have unhappy home lives & 0.156 \\
\hline C67 & $\mathrm{m}$ & $\begin{array}{l}\text { Teachers' racism impacts English Learners } \\
\text { achievement }\end{array}$ & 33 \\
\hline $\mathrm{C} 44$ & Language Skills & English Learners have weaker language skills & 0.178 \\
\hline
\end{tabular}




\begin{tabular}{|c|c|c|c|}
\hline $\mathrm{C} 43$ & Language Skills & English Learners can't speak standard English & 0.197 \\
\hline $\mathrm{C} 45$ & Language skills & English Learners need to be immersed in English-only & 0.231 \\
\hline $\mathrm{C} 71$ & $\begin{array}{l}\text { Training \& Culturally } \\
\text { Responsive }\end{array}$ & $\begin{array}{l}\text { Most teachers are not prepared in working with English } \\
\text { Learners }\end{array}$ & 0.232 \\
\hline $\mathrm{C} 78$ & Unawareness & Teachers lack awareness about English Learners & 0.250 \\
\hline $\mathrm{C} 42$ & Language Skills & $\begin{array}{l}\text { English Learners can't speak their native language } \\
\text { correctly }\end{array}$ & 0.263 \\
\hline C54 & $\begin{array}{l}\text { Language Learning } \\
\text { Process }\end{array}$ & $\begin{array}{l}\text { Relying on their native language is a barrier to learning } \\
\text { English }\end{array}$ & 0.273 \\
\hline C19 & Assimilation & English Learners come from low income families & 0.276 \\
\hline $\mathrm{C} 28$ & $\begin{array}{l}\text { Achievement \& } \\
\text { Expectations }\end{array}$ & $\begin{array}{l}\text { Mainstream teachers are responsible for English } \\
\text { Learners' achievement }\end{array}$ & 0.311 \\
\hline C89 & $\begin{array}{l}\text { Educational } \\
\text { Challenges }\end{array}$ & $\begin{array}{l}\text { Teaching language minority students successfully } \\
\text { means above all challenging one's attitudes toward the } \\
\text { students, their languages and cultures, and their } \\
\text { communities }\end{array}$ & 0.322 \\
\hline C60 & White-Savior & $\begin{array}{l}\text { English Learners will not succeed without a native } \\
\text { English-speaking role model }\end{array}$ & 0.334 \\
\hline $\mathrm{C} 38$ & Parents Influence & $\begin{array}{l}\text { English Learners parents do not care about education } \\
\text { and don't want their children learning English }\end{array}$ & 0.334 \\
\hline C61 & White-Savior & $\begin{array}{l}\text { English Learners need to be helped become } \\
\text { Americanized }\end{array}$ & 0.335 \\
\hline $\mathrm{C} 18$ & Assimilation & English Learners are poor & 0.342 \\
\hline C91 & $\begin{array}{l}\text { Differentiated } \\
\text { Instruction }\end{array}$ & $\begin{array}{l}\text { Teachers should differentiate instruction and } \\
\text { assessment for English Learners }\end{array}$ & 0.346 \\
\hline $\mathrm{C} 83$ & $\begin{array}{l}\text { Experience teaching } \\
\text { ELs }\end{array}$ & $\begin{array}{l}\text { Teaching English Learners is a challenging and } \\
\text { rewarding experience }\end{array}$ & 0.351 \\
\hline C50 & Inclusion & $\begin{array}{l}\text { English Learners should not be placed in a regular } \\
\text { classroom until they are fluent in English }\end{array}$ & 0.376 \\
\hline $\mathrm{C} 81$ & $\begin{array}{l}\text { Origin of English } \\
\text { Learners }\end{array}$ & All English Learners are students of color & 0.394 \\
\hline $\mathrm{C} 07$ & Intelligence & $\begin{array}{l}\text { English Learners have street smarts but not school } \\
\text { smarts }\end{array}$ & 0.419 \\
\hline $\mathrm{C} 06$ & Intelligence & $\begin{array}{l}\text { English Learners have little knowledge to build upon } \\
\text { the classroom }\end{array}$ & 0.442 \\
\hline $\mathrm{C} 40$ & Parents Influence & $\begin{array}{l}\text { English Learners struggle because their parents do not } \\
\text { care about their education }\end{array}$ & 0.454 \\
\hline $\mathrm{C} 08$ & Intelligence & English Learners with an accent are less intelligent & 0.455 \\
\hline $\mathrm{C} 05$ & Intelligence & $\begin{array}{l}\text { English Learners have difficulties because they are not } \\
\text { very intelligent }\end{array}$ & 0.485 \\
\hline $\mathrm{C} 80$ & $\begin{array}{l}\text { Origin of English } \\
\text { Learners }\end{array}$ & $\begin{array}{l}\text { English Learners from Spanish-speaking countries tend } \\
\text { to be more difficult to work with than students from } \\
\text { European countries }\end{array}$ & 0.491 \\
\hline
\end{tabular}




\begin{tabular}{|c|c|c|c|}
\hline $\mathrm{C} 13$ & Immigration & $\begin{array}{l}\text { English Learners are typically illegal immigrants and } \\
\text { drain tax payer resources }\end{array}$ & 0.496 \\
\hline $\mathrm{C} 24$ & $\begin{array}{l}\text { Achievement \& } \\
\text { Expectations }\end{array}$ & $\begin{array}{l}\text { English Learners are so far behind they will never catch } \\
\text { up }\end{array}$ & 0.503 \\
\hline $\mathrm{C} 04$ & Intelligence & $\begin{array}{l}\text { If English Learners would be more intelligent they } \\
\text { would learn English more quickly }\end{array}$ & 0.516 \\
\hline $\mathrm{C} 21$ & Assimilation & $\begin{array}{l}\text { The more English Learners insist in maintaining their } \\
\text { culture and language the slower they will be to } \\
\text { assimilate and learn English and/or the worst off they } \\
\text { will be }\end{array}$ & 0.522 \\
\hline $\mathrm{C} 01$ & $\begin{array}{l}\text { Personality \& } \\
\text { Behavior }\end{array}$ & $\begin{array}{l}\text { English Learners are lazy and don't care about their } \\
\text { education }\end{array}$ & 0.528 \\
\hline C51 & Inclusion & $\begin{array}{l}\text { Having English Learner students in our classrooms is a } \\
\text { gift }\end{array}$ & 0.529 \\
\hline $\mathrm{C} 17$ & $\begin{array}{c}\text { Segregation \& Lack of } \\
\text { Support }\end{array}$ & $\begin{array}{l}\text { English Learners tend to go to the worst schools, and } \\
\text { the worst schools have the most English Learners }\end{array}$ & 0.558 \\
\hline C64 & $\begin{array}{l}\text { Fear of English } \\
\text { Learners }\end{array}$ & $\begin{array}{l}\text { English Learners are aggressive; I would worry for my } \\
\text { safety in teaching in a school with a lot of English } \\
\text { Learners }\end{array}$ & 0.565 \\
\hline $\mathrm{C} 02$ & $\begin{array}{l}\text { Personality \& } \\
\text { Behavior }\end{array}$ & English Learners are members of a gang & 0.578 \\
\hline $\mathrm{C} 25$ & $\begin{array}{l}\text { Achievement \& } \\
\text { Expectations }\end{array}$ & Teachers have low expectations from English Learners & 0.762 \\
\hline $\mathrm{C} 23$ & $\begin{array}{l}\text { Achievement \& } \\
\text { Expectations }\end{array}$ & $\begin{array}{l}\text { English Learners' teachers should not be held } \\
\text { accountable for their achievement }\end{array}$ & 0.813 \\
\hline $\mathrm{C} 82$ & $\begin{array}{l}\text { Experience teaching } \\
\text { ELs }\end{array}$ & $\begin{array}{l}\text { Teaching English Learners is a difficult and scary } \\
\text { experience }\end{array}$ & 0.816 \\
\hline C59 & Bilingual Programs & $\begin{array}{l}\text { Bilingual or language programs are not necessary and } \\
\text { divert resources that would be better spent elsewhere, } \\
\text { such as gifted programs }\end{array}$ & 0.860 \\
\hline $\mathrm{C} 86$ & $\begin{array}{l}\text { Experience teaching } \\
\text { ELs }\end{array}$ & $\begin{array}{l}\text { I look forward to having English Learner students in } \\
\text { my classroom }\end{array}$ & 0.902 \\
\hline C84 & $\begin{array}{l}\text { Experience teaching } \\
\text { ELs }\end{array}$ & $\begin{array}{l}\text { Teaching English Learners has made me a better } \\
\text { teacher }\end{array}$ & 0.911 \\
\hline C68 & $\begin{array}{l}\text { Language \& Cultural } \\
\text { Collisions }\end{array}$ & $\begin{array}{l}\text { Only teachers of color can be effective teaching } \\
\text { English Learners or relate to English Learner students }\end{array}$ & 0.943 \\
\hline $\mathrm{C} 30$ & Color-Blind & I desire to teach English Learner student & 0.950 \\
\hline $\mathrm{C} 74$ & $\begin{array}{l}\text { Training \& Culturally } \\
\text { Responsive }\end{array}$ & $\begin{array}{l}\text { Training all teachers to work with English Learners is a } \\
\text { waste of resources }\end{array}$ & 1.011 \\
\hline C73 & $\begin{array}{l}\text { Training \& Culturally } \\
\text { Responsive }\end{array}$ & $\begin{array}{l}\text { Most teachers don't want to work with English } \\
\text { Learners }\end{array}$ & 1.082 \\
\hline C76 & $\begin{array}{l}\text { Training \& Culturally } \\
\text { Responsive }\end{array}$ & $\begin{array}{l}\text { I know specific strategies for designing instruction that } \\
\text { is responsive to students' language needs }\end{array}$ & 1.266 \\
\hline
\end{tabular}




\begin{tabular}{|c|c|c|c|}
\hline $\mathrm{C} 88$ & $\begin{array}{l}\text { Experience teaching } \\
\text { ELs }\end{array}$ & $\begin{array}{l}\text { I have had the opportunity to develop close } \\
\text { relationships with English Learner students and/or their } \\
\text { families }\end{array}$ & 1.368 \\
\hline $\mathrm{C} 12$ & $\begin{array}{l}\text { Relate to English } \\
\text { Learners }\end{array}$ & $\begin{array}{l}\text { I can relate to the struggles English Learners encounter } \\
\text { and understand their needs }\end{array}$ & 1.437 \\
\hline C87 & $\begin{array}{l}\text { Experience teaching } \\
\text { ELs }\end{array}$ & I have worked with a lot of English Learner students & 1.461 \\
\hline C77 & $\begin{array}{l}\text { Training \& Culturally } \\
\text { Responsive }\end{array}$ & $\begin{array}{l}\text { I know specific strategies for designing instruction that } \\
\text { is responsive to students' cultural differences }\end{array}$ & 1.472 \\
\hline C66 & $\begin{array}{l}\text { Fear of English } \\
\text { Learners }\end{array}$ & I feel prepared in teaching English Learners & 1.494 \\
\hline C29 & $\begin{array}{l}\text { Achievement \& } \\
\text { Expectations }\end{array}$ & $\begin{array}{l}\text { Mainstream teachers are responsible for English } \\
\text { Learners' achievement }\end{array}$ & 1.495 \\
\hline C65 & $\begin{array}{l}\text { Fear of English } \\
\text { Learners }\end{array}$ & $\begin{array}{l}\text { I fear teaching English Learners, I would be } \\
\text { uncomfortable }\end{array}$ & 1.597 \\
\hline C11 & $\begin{array}{l}\text { Relate to English } \\
\text { Learners }\end{array}$ & $\begin{array}{l}\text { I feel more comfortable working with English Learners } \\
\text { than other minority students }\end{array}$ & 1.647 \\
\hline C69 & $\begin{array}{l}\text { Language \& Cultural } \\
\text { Collisions }\end{array}$ & $\begin{array}{l}\text { I prefer to teach students from similar backgrounds as } \\
\text { me. }\end{array}$ & 1.810 \\
\hline
\end{tabular}


APPENDIX L: INDSCAL SUBGROUP CONFIGURATION - DIMENSION 3 RANKINGS

\begin{tabular}{|c|c|c|c|}
\hline Card \# & Category & Statement Text & Dim. 3 \\
\hline $\mathrm{C} 78$ & Unawareness & Teachers lack awareness about English Learners & -2.429 \\
\hline C71 & $\begin{array}{l}\text { Training \& } \\
\text { Culturally } \\
\text { Responsive }\end{array}$ & $\begin{array}{l}\text { Most teachers are not prepared in working with } \\
\text { English Learners }\end{array}$ & -2.312 \\
\hline $\mathrm{C} 15$ & $\begin{array}{l}\text { Segregation \& Lack } \\
\text { of Support }\end{array}$ & $\begin{array}{l}\text { English Learners often do not receive support in } \\
\text { schools }\end{array}$ & -2.195 \\
\hline C90 & $\begin{array}{l}\text { Educational } \\
\text { Challenges }\end{array}$ & $\begin{array}{l}\text { The low achievement of English Learner students } \\
\text { often is the result of negative teacher attitudes } \\
\text { towards them }\end{array}$ & -2.089 \\
\hline $\mathrm{C} 70$ & $\begin{array}{l}\text { Language \& } \\
\text { Cultural Collisions }\end{array}$ & $\begin{array}{l}\text { Cultural and linguistic differences between students } \\
\text { and teachers inhibits effective education of English } \\
\text { Learners }\end{array}$ & -1.919 \\
\hline $\mathrm{C} 25$ & $\begin{array}{l}\text { Achievement \& } \\
\text { Expectations }\end{array}$ & $\begin{array}{l}\text { Teachers have low expectations from English } \\
\text { Learners }\end{array}$ & -1.814 \\
\hline C67 & Racism & $\begin{array}{l}\text { Teachers' racism impacts English Learners } \\
\text { achievement }\end{array}$ & -1.812 \\
\hline $\mathrm{C} 73$ & $\begin{array}{l}\text { Training \& } \\
\text { Culturally } \\
\text { Responsive }\end{array}$ & $\begin{array}{l}\text { Most teachers don't want to work with English } \\
\text { Learners }\end{array}$ & -1.438 \\
\hline $\mathrm{C} 28$ & $\begin{array}{l}\text { Achievement \& } \\
\text { Expectations }\end{array}$ & $\begin{array}{l}\text { Mainstream teachers are responsible for English } \\
\text { Learners' achievement }\end{array}$ & -1.332 \\
\hline $\mathrm{C} 72$ & $\begin{array}{l}\text { Culturally } \\
\text { Responsive }\end{array}$ & $\begin{array}{l}\text { Teachers need special training in working with } \\
\text { English Learners }\end{array}$ & -1.249 \\
\hline C62 & White-Savior & $\begin{array}{l}\text { English Learner students need support from } \\
\text { teachers beyond academics }\end{array}$ & -1.224 \\
\hline $\mathrm{C} 29$ & $\begin{array}{l}\text { Achievement \& } \\
\text { Expectations }\end{array}$ & $\begin{array}{l}\text { Mainstream teachers are responsible for English } \\
\text { Learners' achievement }\end{array}$ & -1.191 \\
\hline $\mathrm{C} 82$ & $\begin{array}{l}\text { Experience teaching } \\
\text { ELs }\end{array}$ & $\begin{array}{l}\text { Teaching English Learners is a difficult and scary } \\
\text { experience }\end{array}$ & -1.155 \\
\hline C93 & Equitable Education & $\begin{array}{l}\text { English Learner students deserve more support and } \\
\text { caring teachers in schools }\end{array}$ & -1.091 \\
\hline $\mathrm{C} 23$ & $\begin{array}{l}\text { Achievement \& } \\
\text { Expectations }\end{array}$ & $\begin{array}{l}\text { English Learners' teachers should not be held } \\
\text { accountable for their achievement }\end{array}$ & -1.053 \\
\hline C74 & $\begin{array}{l}\text { Training \& } \\
\text { Culturally } \\
\text { Responsive }\end{array}$ & $\begin{array}{l}\text { Training all teachers to work with English Learners } \\
\text { is a waste of resources }\end{array}$ & -0.970 \\
\hline C91 & $\begin{array}{l}\text { Differentiated } \\
\text { Instruction }\end{array}$ & $\begin{array}{l}\text { Teachers should differentiate instruction and } \\
\text { assessment for English Learners }\end{array}$ & -0.886 \\
\hline C37 & $\begin{array}{c}\text { Cultural } \\
\text { Capital/Deprived }\end{array}$ & $\begin{array}{l}\text { English Learner students will succeed in school } \\
\text { when mainstream teachers affirm their cultural } \\
\text { identities }\end{array}$ & -0.850 \\
\hline
\end{tabular}




\begin{tabular}{|c|c|c|c|}
\hline $\mathrm{C} 35$ & Culture Influence & $\begin{array}{l}\text { It is important for mainstream teacher to understand } \\
\text { and know how English Learner parents' view } \\
\text { schools and learning }\end{array}$ & -0.755 \\
\hline C68 & $\begin{array}{c}\text { Language \& } \\
\text { Cultural Collisions }\end{array}$ & $\begin{array}{l}\text { Only teachers of color can be effective teaching } \\
\text { English Learners or relate to English Learner } \\
\text { students }\end{array}$ & -0.733 \\
\hline C89 & $\begin{array}{l}\text { Educational } \\
\text { Challenges }\end{array}$ & $\begin{array}{l}\text { Teaching language minority students successfully } \\
\text { means above all challenging one's attitudes toward } \\
\text { the students, their languages and cultures, and their } \\
\text { communities }\end{array}$ & -0.724 \\
\hline C65 & $\begin{array}{l}\text { Fear of English } \\
\text { Learners }\end{array}$ & $\begin{array}{l}\text { I fear teaching English Learners, I would be } \\
\text { uncomfortable }\end{array}$ & -0.647 \\
\hline C92 & $\begin{array}{l}\text { Differentiated } \\
\text { Instruction }\end{array}$ & $\begin{array}{l}\text { It is the responsibility of teachers to be aware of the } \\
\text { language diversity of learners in their classrooms } \\
\text { and to structure their lessons, as well as adjust their } \\
\text { teaching styles, to meet these students' needs }\end{array}$ & -0.635 \\
\hline C63 & White-Savior & $\begin{array}{l}\text { English Learners need teachers that provide a } \\
\text { support system and guides them in schools }\end{array}$ & -0.581 \\
\hline $\mathrm{C} 75$ & $\begin{array}{l}\text { Training \& } \\
\text { Culturally } \\
\text { Responsive }\end{array}$ & $\begin{array}{l}\text { English Learners need teachers that can create } \\
\text { culturally inclusive learning materials }\end{array}$ & -0.444 \\
\hline C53 & Inclusion & $\begin{array}{l}\text { It is important for English Learner students to feel } \\
\text { comfortable and receive teacher assistance when } \\
\text { transitioning into a general education classroom }\end{array}$ & -0.409 \\
\hline $\mathrm{C} 06$ & Intelligence & $\begin{array}{l}\text { English Learners have little knowledge to build } \\
\text { upon the classroom }\end{array}$ & -0.374 \\
\hline C64 & $\begin{array}{l}\text { Fear of English } \\
\text { Learners }\end{array}$ & $\begin{array}{l}\text { English Learners are aggressive; I would worry for } \\
\text { my safety in teaching in a school with a lot of } \\
\text { English Learners }\end{array}$ & -0.352 \\
\hline $\mathrm{C} 04$ & Intelligence & $\begin{array}{l}\text { If English Learners would be more intelligent they } \\
\text { would learn English more quickly }\end{array}$ & -0.300 \\
\hline $\mathrm{C} 05$ & Intelligence & $\begin{array}{l}\text { English Learners have difficulties because they are } \\
\text { not very intelligent }\end{array}$ & -0.271 \\
\hline $\mathrm{C} 01$ & $\begin{array}{c}\text { Personality \& } \\
\text { Behavior }\end{array}$ & $\begin{array}{l}\text { English Learners are lazy and don't care about their } \\
\text { education }\end{array}$ & -0.252 \\
\hline C59 & Bilingual Programs & $\begin{array}{l}\text { Bilingual or language programs are not necessary } \\
\text { and divert resources that would be better spent } \\
\text { elsewhere, such as gifted programs }\end{array}$ & -0.230 \\
\hline C54 & $\begin{array}{l}\text { Language Learning } \\
\text { Process }\end{array}$ & $\begin{array}{l}\text { Relying on their native language is a barrier to } \\
\text { learning English }\end{array}$ & -0.227 \\
\hline $\mathrm{C} 02$ & $\begin{array}{c}\text { Personality \& } \\
\text { Behavior }\end{array}$ & English Learners are members of a gang & -0.210 \\
\hline $\mathrm{C} 80$ & $\begin{array}{l}\text { Origin of English } \\
\text { Learners }\end{array}$ & $\begin{array}{l}\text { English Learners from Spanish-speaking countries } \\
\text { tend to be more difficult to work with than students } \\
\text { from European countries }\end{array}$ & -0.198 \\
\hline
\end{tabular}




\begin{tabular}{|c|c|c|c|}
\hline $\mathrm{C} 24$ & $\begin{array}{l}\text { Achievement \& } \\
\text { Expectations }\end{array}$ & $\begin{array}{l}\text { English Learners are so far behind they will never } \\
\text { catch up }\end{array}$ & -0.186 \\
\hline $\mathrm{C} 17$ & $\begin{array}{l}\text { Segregation \& Lack } \\
\text { of Support }\end{array}$ & $\begin{array}{l}\text { English Learners tend to go to the worst schools, } \\
\text { and the worst schools have the most English } \\
\text { Learners }\end{array}$ & -0.184 \\
\hline $\mathrm{C} 22$ & At-Risk & $\begin{array}{l}\text { English Learners are at a higher risk for behavioral } \\
\text { and/or learning difficulties }\end{array}$ & -0.135 \\
\hline $\mathrm{C} 18$ & Assimilation & English Learners are poor & -0.127 \\
\hline $\mathrm{C} 16$ & $\begin{array}{l}\text { Segregation \& Lack } \\
\text { of Support }\end{array}$ & $\begin{array}{l}\text { English Learners often do not receive the support } \\
\text { they need from home }\end{array}$ & -0.122 \\
\hline $\mathrm{C} 08$ & Intelligence & English Learners with an accent are less intelligent & -0.113 \\
\hline $\mathrm{C} 60$ & White-Savior & $\begin{array}{l}\text { English Learners will not succeed without a native } \\
\text { English-speaking role model }\end{array}$ & -0.091 \\
\hline $\mathrm{C} 81$ & $\begin{array}{l}\text { Origin of English } \\
\text { Learners }\end{array}$ & All English Learners are students of color & -0.089 \\
\hline $\mathrm{C} 44$ & Language Skills & English Learners have weaker language skills & -0.082 \\
\hline $\mathrm{C} 21$ & Assimilation & $\begin{array}{l}\text { The more English Learners insist in maintaining } \\
\text { their culture and language the slower they will be to } \\
\text { assimilate and learn English and/or the worst off } \\
\text { they will be }\end{array}$ & -0.062 \\
\hline $\mathrm{C} 43$ & Language Skills & English Learners can't speak standard English & -0.058 \\
\hline $\mathrm{C} 13$ & Immigration & $\begin{array}{l}\text { English Learners are typically illegal immigrants } \\
\text { and drain tax payer resources }\end{array}$ & -0.048 \\
\hline $\mathrm{C} 07$ & Intelligence & $\begin{array}{l}\text { English Learners have street smarts but not school } \\
\text { smarts }\end{array}$ & -0.027 \\
\hline C79 & $\begin{array}{l}\text { Origin of English } \\
\text { Learners }\end{array}$ & $\begin{array}{l}\text { Majority of English Learners speak Spanish and } \\
\text { come from Mexico }\end{array}$ & -0.009 \\
\hline C19 & Assimilation & English Learners come from low income families & 0.001 \\
\hline $\mathrm{C} 50$ & Inclusion & $\begin{array}{l}\text { English Learners should not be placed in a regular } \\
\text { classroom until they are fluent in English }\end{array}$ & 0.002 \\
\hline $\mathrm{C} 40$ & Parents Influence & $\begin{array}{l}\text { English Learners struggle because their parents do } \\
\text { not care about their education }\end{array}$ & 0.007 \\
\hline $\mathrm{C} 38$ & Parents Influence & $\begin{array}{l}\text { English Learners parents do not care about } \\
\text { education and don't want their children learning } \\
\text { English }\end{array}$ & 0.024 \\
\hline $\mathrm{C} 14$ & Immigration & $\begin{array}{l}\text { English Learners' families do not want to learn } \\
\text { English }\end{array}$ & 0.032 \\
\hline $\mathrm{C} 32$ & Culture Influence & $\begin{array}{l}\text { English Learner students are not exposed to cultural } \\
\text { enriching experiences by their families }\end{array}$ & 0.038 \\
\hline C42 & Language Skills & $\begin{array}{l}\text { English Learners can't speak their native language } \\
\text { correctly }\end{array}$ & 0.073 \\
\hline $\mathrm{C} 41$ & Home Life & English Learners have unhappy home lives & 0.078 \\
\hline $\mathrm{C} 45$ & Language skills & $\begin{array}{l}\text { English Learners need to be immersed in English- } \\
\text { only }\end{array}$ & 0.112 \\
\hline
\end{tabular}




\begin{tabular}{|c|c|c|c|}
\hline C55 & $\begin{array}{l}\text { Language Learning } \\
\text { Process }\end{array}$ & $\begin{array}{l}\text { English Learners second language acquisition } \\
\text { process involves accessing their native language }\end{array}$ & 0.232 \\
\hline C61 & White-Savior & $\begin{array}{l}\text { English Learners need to be helped become } \\
\text { Americanized }\end{array}$ & 0.296 \\
\hline C58 & $\begin{array}{l}\text { Language Learning } \\
\text { Process }\end{array}$ & $\begin{array}{l}\text { English Learners who learn to read and write in } \\
\text { their native language first acquire stronger English } \\
\text { language and literacy skills later. }\end{array}$ & 0.320 \\
\hline C57 & $\begin{array}{l}\text { Language Learning } \\
\text { Process }\end{array}$ & $\begin{array}{l}\text { English Learners social language skills occur } \\
\text { before academic language skills }\end{array}$ & 0.326 \\
\hline C69 & $\begin{array}{c}\text { Language \& } \\
\text { Cultural Collisions }\end{array}$ & $\begin{array}{l}\text { I prefer to teach students from similar backgrounds } \\
\text { as me. }\end{array}$ & 0.400 \\
\hline $\mathrm{C} 83$ & $\begin{array}{l}\text { Experience teaching } \\
\text { ELs }\end{array}$ & $\begin{array}{l}\text { Teaching English Learners is a challenging and } \\
\text { rewarding experience }\end{array}$ & 0.661 \\
\hline C46 & Language skills & $\begin{array}{l}\text { Keeping and strengthening native language skills } \\
\text { (L1) of English Learners helps their ability to learn } \\
\text { English }\end{array}$ & 0.736 \\
\hline C52 & Inclusion & $\begin{array}{l}\text { English Learners' inclusion in general } \\
\text { education/mainstream classroom can be beneficial } \\
\text { for themselves and others }\end{array}$ & 0.740 \\
\hline C77 & $\begin{array}{l}\text { Training \& } \\
\text { Culturally } \\
\text { Responsive }\end{array}$ & $\begin{array}{l}\text { I know specific strategies for designing instruction } \\
\text { that is responsive to students' cultural differences }\end{array}$ & 0.865 \\
\hline $\mathrm{C} 03$ & $\begin{array}{l}\text { Personality \& } \\
\text { Behavior }\end{array}$ & $\begin{array}{l}\text { English Learners care about their education, thus } \\
\text { they are well-behaved }\end{array}$ & 0.872 \\
\hline $\mathrm{C} 27$ & $\begin{array}{l}\text { Achievement \& } \\
\text { Expectations }\end{array}$ & $\begin{array}{l}\text { English Learners will be academically successful, } \\
\text { and are just as capable of going to college as native } \\
\text { English speakers }\end{array}$ & 0.874 \\
\hline $\mathrm{C} 09$ & Intelligence & $\begin{array}{l}\text { English Learners language skills are not indicative } \\
\text { of their intelligence }\end{array}$ & 0.921 \\
\hline C56 & $\begin{array}{l}\text { Language Learning } \\
\text { Process }\end{array}$ & $\begin{array}{l}\text { Spanish language skills are helpful in learning } \\
\text { English language as a second language }\end{array}$ & 0.932 \\
\hline C49 & Language Skills & $\begin{array}{l}\text { Bilingual students have stronger higher-level } \\
\text { thinking skills than students who only speak } \\
\text { English }\end{array}$ & 0.948 \\
\hline $\mathrm{C} 20$ & Assimilation & $\begin{array}{l}\text { The faster English Learners students assimilate the } \\
\text { better of they will be }\end{array}$ & 0.971 \\
\hline C84 & $\begin{array}{l}\text { Experience teaching } \\
\text { ELs }\end{array}$ & $\begin{array}{l}\text { Teaching English Learners has made me a better } \\
\text { teacher }\end{array}$ & 0.974 \\
\hline C51 & Inclusion & $\begin{array}{l}\text { Having English Learner students in our classrooms } \\
\text { is a gift }\end{array}$ & 0.981 \\
\hline $\mathrm{C} 10$ & Intelligence & $\begin{array}{l}\text { English Learners have the capacity to learn despite } \\
\text { their language skills }\end{array}$ & 1.006 \\
\hline $\mathrm{C} 85$ & $\begin{array}{l}\text { Experience teaching } \\
\text { ELs }\end{array}$ & $\begin{array}{l}\text { Teaching English Learners is an empathy building } \\
\text { experience }\end{array}$ & 1.014 \\
\hline
\end{tabular}




\begin{tabular}{|c|c|c|c|}
\hline $\mathrm{C} 33$ & Culture Influence & $\begin{array}{l}\text { English Learners knowledge is due to their } \\
\text { enriching cultural experiences }\end{array}$ & 1.055 \\
\hline $\mathrm{C} 26$ & $\begin{array}{l}\text { Achievement \& } \\
\text { Expectations }\end{array}$ & $\begin{array}{l}\text { English Learner students are more motivated to } \\
\text { succeed than many of their native English-speaking } \\
\text { peers }\end{array}$ & 1.074 \\
\hline $\mathrm{C} 36$ & $\begin{array}{c}\text { Cultural } \\
\text { Capital/Deprived }\end{array}$ & $\begin{array}{l}\text { English Learner students have many strengths that } \\
\text { they bring with them into the classroom }\end{array}$ & 1.097 \\
\hline $\mathrm{C} 48$ & Language Skills & Bilingualism benefits English Learners & 1.134 \\
\hline $\mathrm{C} 31$ & Culture Influence & $\begin{array}{l}\text { English Learner students' families expose them to a } \\
\text { wide range of cultural experiences }\end{array}$ & 1.282 \\
\hline $\mathrm{C} 30$ & Color-Blind & I desire to teach English Learner student & 1.368 \\
\hline C86 & $\begin{array}{l}\text { Experience teaching } \\
\text { ELs }\end{array}$ & $\begin{array}{l}\text { I look forward to having English Learner students } \\
\text { in my classroom }\end{array}$ & 1.370 \\
\hline C76 & $\begin{array}{l}\text { Training \& } \\
\text { Culturally } \\
\text { Responsive }\end{array}$ & $\begin{array}{l}\text { I know specific strategies for designing instruction } \\
\text { that is responsive to students' language needs }\end{array}$ & 1.372 \\
\hline C87 & $\begin{array}{l}\text { Experience teaching } \\
\text { ELs }\end{array}$ & $\begin{array}{l}\text { I have worked with a lot of English Learner } \\
\text { students }\end{array}$ & 1.469 \\
\hline C66 & $\begin{array}{l}\text { Fear of English } \\
\text { Learners }\end{array}$ & I feel prepared in teaching English Learners & 1.508 \\
\hline C39 & Parents Influence & $\begin{array}{l}\text { English Learner's parents want their children to } \\
\text { learn English and/or be bilingual }\end{array}$ & 1.524 \\
\hline $\mathrm{C} 88$ & $\begin{array}{l}\text { Experience teaching } \\
\text { ELs }\end{array}$ & $\begin{array}{l}\text { I have had the opportunity to develop close } \\
\text { relationships with English Learner students and/or } \\
\text { their families }\end{array}$ & 1.586 \\
\hline $\mathrm{C} 11$ & $\begin{array}{l}\text { Relate to English } \\
\text { Learners }\end{array}$ & $\begin{array}{l}\text { I feel more comfortable working with English } \\
\text { Learners than other minority students }\end{array}$ & 1.732 \\
\hline $\mathrm{C} 12$ & $\begin{array}{l}\text { Relate to English } \\
\text { Learners }\end{array}$ & $\begin{array}{l}\text { I can relate to the struggles English Learners } \\
\text { encounter and understand their needs }\end{array}$ & 1.787 \\
\hline $\mathrm{C} 47$ & Language Skills & $\begin{array}{l}\text { All students in the United States should learn to } \\
\text { speak more than one language }\end{array}$ & 1.891 \\
\hline
\end{tabular}

